JULIANO PHILIPPI GERENT

\title{
A SIMULAÇÃO ANALÓGICA DE MANOBRAS NÃO TRIPULADAS DE NAVIOS NA OTIMIZAÇÃO DE PROJETOS E OPERAÇÕES PORTUÁRIAS
}

São Paulo 


\title{
A SIMULAÇÃO ANALÓGICA DE MANOBRAS NÃO TRIPULADAS DE NAVIOS NA OTIMIZAÇÃO DE PROJETOS E OPERAÇÕES PORTUÁRIAS
}

\author{
Dissertação apresentada à Escola \\ Politécnica da Universidade de São Paulo \\ para obtenção do título de mestre em \\ Engenharia Civil
}

Área de Concentração:

Obras Hidráulicas

Orientador:

Prof. Dr. Paolo Alfredini

\section{São Paulo}




\section{RESUMO}

A simulação analógica das manobras não tripuladas de navios em modelo físico tridimensional, nas operações de atracação, desatracação e acessibilidade aos Terminais Portuários, consiste numa importante ferramenta para avaliação da segurança aquaviária. Avaliam-se situações de risco, além de proporcionar ganhos de produtividade, como otimização dos procedimentos de manobras e abertura de novas janelas temporais operacionais.

Com o uso de diferentes modelos de navios rádio-controlados, manobrados por Pilotos reais de Associação de Práticos do porto em estudo, equipados com sistema de rastreamento e possibilidade da utilização de até quatro rebocadores simultaneamente, viabiliza-se a realização de uma gama de manobras que demandariam, dependendo da escala temporal do modelo, uma ordem de grandeza a mais de tempo em um navio real, bem como inúmeros riscos à segurança da navegação.

Neste trabalho foi apresentada uma revisão bibliográfica sobre o tema, seguida da análise crítica de diferentes estudos de casos realizados, estudados no SIAMA (Simulador analógico de manobras não tripuladas) do LHEPUSP - Laboratório de Hidráulica da Escola Politécnica da Universidade de São Paulo, enfatizando-se os ganhos operacionais obtidos (segurança e produtividade). 


\begin{abstract}
The analogical simulation of ships manoeuvres of berthing, departure and approach in tridimensional physical model for Port Terminals purposes, has been considered a valuable technical tool for port operational planning and safety improvings. Indeed, it is possible to evaluate the manoeuvring risks of new operational scenarios or windows, contributing for the vessel and berth security,
\end{abstract}

Using different radio-controlled vessel models, with tracking system, manoeuvred with tug aid by Pilots of the Port local Association and evaluated by port masters, advisors stackholders; it is possible to perform much more manoeuvring tests, with no risk than real tests, with time tests about ten times lesser.

A detailed bibliographical review about this subject was made, followed by a critical analysis of different case studies performed and studied by the SIAMA (Analogical Manoeuvring Simulator in portuguese) of the LHEPUSP - Hydraulic Laboratory of São Paulo University Polytechnic School in portuguese, emphasizing the operational improvements get. 


\section{LISTA DE ILUSTRAÇÕES}

Figura 1: Diagrama de Moody-Rouse $\quad 15$

Figura 2: Foto zenital do modelo de Ponta da Madeira 23

Figura 3: Realização de manobra no modelo físico TIG - Terminal llha Guaíba 24

Figura 4: Realização de manobra no modelo do Terminal da ALUMAR 24

Figura 5: paredes limites do modelo físico na fase construtiva 25

Figura 6: Georeferenciamento do modelo de Ponta da Madeira 26

Figura 7: Projeção da batimetria $\quad 27$

Figura 8: Nivelamento das curvas de nível 28

Figura 9: Módulos de PVC 30

Figura 10: Esquema do medidor Venturi 32

Figura 11: Ponta limnimetrica $\quad 38$

Figura 12: placas direcionadoras de correntes $\quad 39$

Figura 13: Ensaio de derivadores no modelo físico PDM 40

Figura 14: Simulação de manobra em Port Revel $\quad 42$

Figura 15: Isolamento do cenário com cortinas pretas 48

Figura 16: Detalhe das cavernas do modelo de navio Chinamax 50

Figura 17: Detalhe das linhas do modelo de navio Chinamax 50

Figura 18: Detalhe do castelo de popa do modelo de navio Chinamax $\quad 51$

Figura 19: llustração de rebocadores auxiliando manobra $\quad 52$

Figura 20: Detalhe de ventilador entubado embutido no casco do navio 53

Figura 21: Relatório de prova de giro realizada com Panamax 55

Figura 22: Calibração do modelo de navio Panamax no SIAMA 56

Figura 23: Vista do interior do controle

Figura 24: Consoles de comandos do navio e rebocadores $\quad 57$

Figura 25: Visualização de manobra de atracação no TMPM 58

Figura 26: Sensores instalados nas defensas do Píer III, Berço Norte, do PDM 61

Figura 27: Gráfico das deformações nas defensas, pelo impacto de modelo de navio Capesize no Píer I do PDM 61

Figura 28: Curva de desempenho da defensa tipo Bridgestone instalada no Píer I do PDM 62

Figura 29: Inauguração do Terminal da ALUMAR em 1984

Figura 30: Obras de ampliação do cais da ALUMAR $\quad 65$

Figura 31: Carta náutica com o Canal de Acesso à ALUMAR 66

Figura 32: Modelo dos berços implantado no SIAMA

Figura 33: Prático realizando manobra de demanda ao Terminal da ALUMAR pelo Canal de Acesso no

SIAMA $\quad 71$

Figura 34: Imagem aérea do Píer III em primeiro plano e do Píer I ao fundo 75

Figura 35: Imagem zenital dos ensaios de desatracação de emergência 78 
Figura 36: Imagem aérea do Píer I em primeiro plano e Porto de Itaqui ao fundo 80

Figura 37: Imagem zenital de manobra de atracação à ré no Cais 108

Figura 38: Execução da obra de expansão do Píer III 84

Figura 39: Atracação por boreste no Píer III Norte $\quad 85$

Figura 40: Atracação por bombordo com giro por bombordo no Píer III Norte 86

Figura 41: Atracação do navio ULOC no Píer IV 90

Figura 42: Localização geográfica do Terminal 92

Figura 43: Terminal do Pólo Siderúrgico implantado em modelo físico 93

Figura 44: Regra original de manobras para o Terminal de Ponta da Madeira 94

Figura 45: Regra atual de manobras para o Terminal de Ponta da Madeira 95 


\section{LISTA DE TABELAS}

Tabela 1 - Evolução da frota de navios porta-contêineres ............................................................... 3

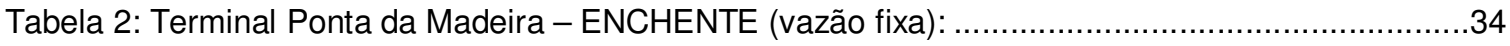

Tabela 3: Terminal Ponta da Madeira - VAZANTE (vazão fixa): ...................................................... 34

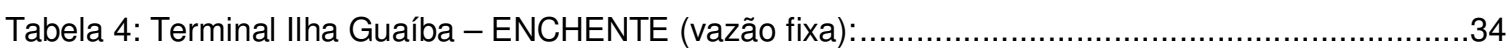

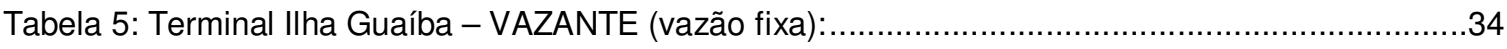

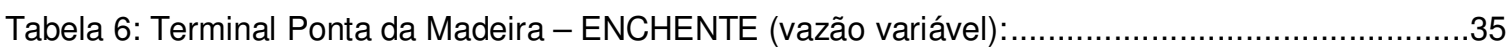

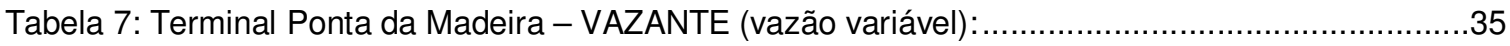

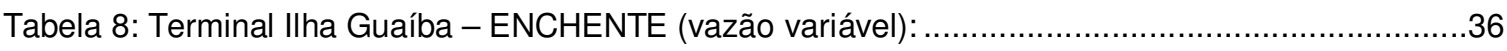

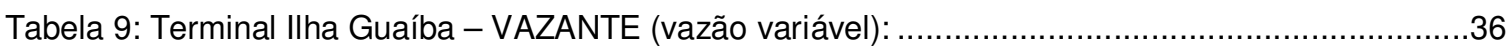

Tabela 10: Dimensões características dos navios instrumentados para manobras ................................49

Tabela 11: Questionário de avaliação das manobras - exemplo de preenchimento de um ensaio ........60

Tabela 12: Comparativo entre os navios que operam na ALUMAR e o Panamax.................................67

Tabela 13: Resumo das manobras simuladas para o Terminal da ALUMAR .....................................72 


\section{LISTA DE SÍMBOLOS}
A: área da seção transversal $\left(\mathrm{m}^{2}\right)$
C: coeficiente de Chézy $\left(\mathrm{m}^{1 / 2} / \mathrm{s}\right)$
D: diâmetro do conduto (m)
E: módulo de elasticidade volumétrica $\left(\mathrm{N} / \mathrm{m}^{2}\right)$
f: coeficiente de atrito de Darcy-Weissbach
Fr: número de Froude
g: aceleração da gravidade $\left(\mathrm{m} / \mathrm{s}^{2}\right)$
i: declividade do leito $(\mathrm{m} / \mathrm{m})$
$\mathrm{J}$ : declividade global da linha de energia $(\mathrm{m} / \mathrm{m})$
$\mathrm{L}$ : dimensão linear $(\mathrm{m})$
$\eta$ : coeficiente de Manning

Ks: rugosidade equivalente do leito $(\mathrm{m})$

p: pressão $\left(\mathrm{kgf} / \mathrm{m}^{2}\right)$

Re: número de Reynolds

$\mathrm{t}: \quad$ tempo (s)

$v$ : velocidade média do escoamento $(\mathrm{m} / \mathrm{s})$

Vcc: voltagem de alimentação

W: número de Weber

$\lambda$ : escala do modelo-relação modelo $(\mathrm{M})$ : real $(\mathrm{P})$

$\mu$ : viscosidade dinâmica do fluido $(\mathrm{kg} / \mathrm{ms})$

v: viscosidade cinemática do fluido $\left(\mathrm{m}^{2} / \mathrm{s}\right)$

$\rho:$ massa específica do fluido $\left(\mathrm{kg} / \mathrm{m}^{3}\right)$

$\sigma:$ coeficiente de tensão superficial do fluido $(\mathrm{N} / \mathrm{m})$ 


\section{GLOSSÁRIO}

- BERÇO DE ATRACAÇÃo: Divisões de um cais, píer ou atracadouro destinado à atracação dos navios.

- BOCA: largura da seção transversal a que se referir; quando expressa sem referências, significa a maior largura do casco.

- BOCA MOLDADA: é a maior largura do casco medida entre as faces exteriores da carena, ou seja, é a maior largura do casco entre as superfícies moldadas.

- BOLLARD PULL: Força de Tração Estática de uma embarcação, normalmente utilizada como medida de força aplicável de cada rebocador a ser utilizado em uma manobra (medida em toneladas força).

- CALADO: É para qualquer ponto que se tome a distância vertical entre a superfície da água e a parte mais baixa do navio naquele ponto.

- DESLOCAMENTO: é o peso da água deslocada pelo navio flutuando em águas tranqüilas. Pelo princípio de Arquimedes, é igual ao peso do navio e tudo que ele contém na condição atual de flutuação.

- DHN: Diretoria de Hidrografia e Navegação (Unidade da Marinha do Brasil)

- DPC: Diretoria de Portos e Costas (Unidade da Marinha do Brasil).

- TBP: Sinônimo de "Deadweight" - Tonelagem do Porte Bruto da embarcação.

- IMO: Sigla de "International Maritime Organization" - Organização Marítima Internacional.

- SPRINGUES: São os cabos de amarração que, quando saindo da proa são orientados para ré, e ao saírem da popa, são orientados para vante.

- LANÇANTES: São os cabos de amarração que, quando na proa estão orientados para vante, e quando na popa orientados para ré; quando a meianau, saindo de bordo de meia-nau para a proa, orientada para vante e quando saindo de bordo de meia-nau para a popa, orientada para ré. Concorrem com os springues para evitar que o navio se mova ao longo do cais ou para fora.

- MARÉ DE SIZíGIA: Maré de grande amplitude, ocorrendo nas fases da lua cheia e lua nova. Nas marés de sizígia, ocorrem os máximos valores de preamar (maré alta) e mínimos valores de baixa-mar (maré baixa); correspondem às ocasiões onde ocorre um alinhamento SOL-TERRA-LUA, 
com a força gravitacional da LUA e do SOL sobre a TERRA somando-se contribuindo para a elevação do nível do mar.

- MARÉ DE QUADRATURA: Maré de menor amplitude, ocorrendo nas fases de quarto crescente e quarto minguante. Nas marés de quadratura, a posição relativa da LUA-TERRA-SOL faz um ângulo de 90 (noventa) graus, indicando que a força gravitacional resultante terá um efeito menor na elevação do nível do mar.

- NÓ: Unidade de velocidade empregada em navegação (equivalente a 1852 m/h ou $1.852 \mathrm{~km} / \mathrm{h})$.

- NORMAM: Sigla de Normas da Autoridade Marítima (competência da Diretoria de Portos e Costas).

- NPCP - MA: Sigla das Normas e Procedimentos da Capitania dos Portos, emitidas pelo Capitão dos Portos do Maranhão.

- TRAVESES: São os cabos de amarração que saem perpendiculares ao cais, sem orientação nem para vante nem para ré. São utilizados para evitar que o navio se afaste do cais por efeito do vento ou da corrente.

- MBL: Carga nominal mínima de ruptura (tf). 


\section{SUMÁRIO}

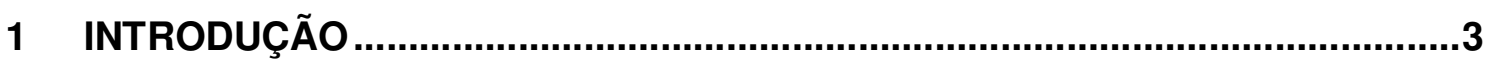

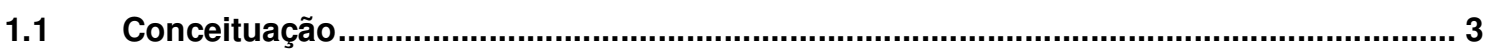

1.2 Objetivo

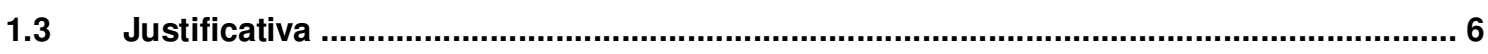

2 REVISÃO BIBLIOGRÁFICA........................................................................

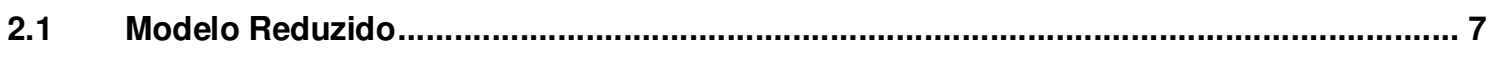

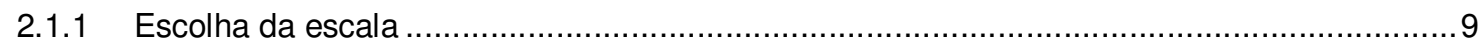

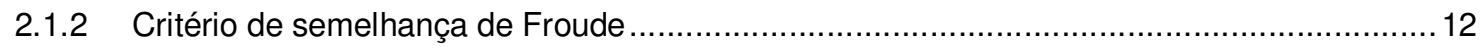

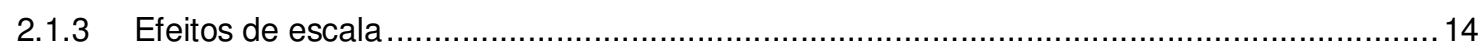

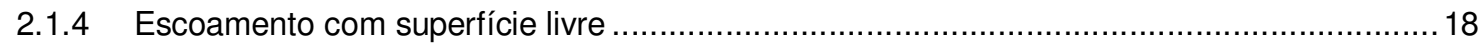

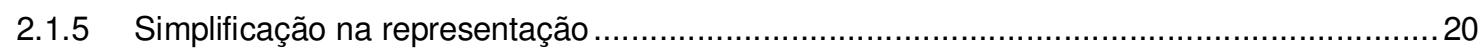

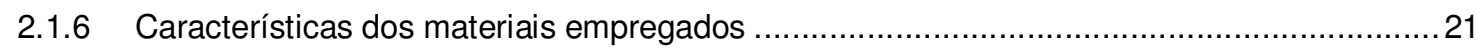

2.2 A construção dos modelos portuários para os Terminais de Ponta da Madeira - MA,

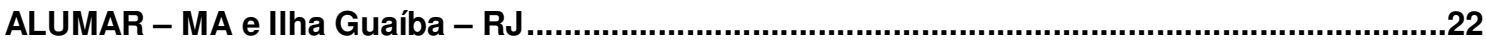

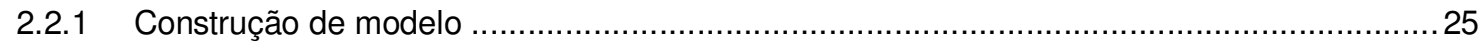

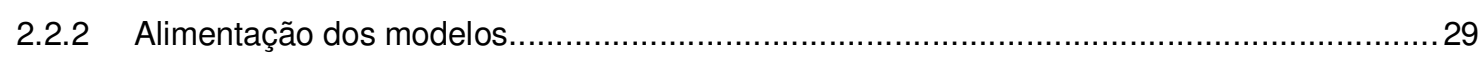

2.2.3 Testes de aferição dos medidores de vazão dos modelos portuários ..................................32

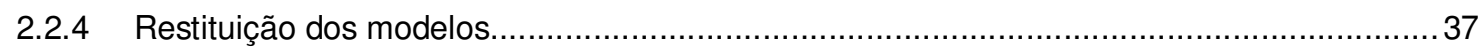

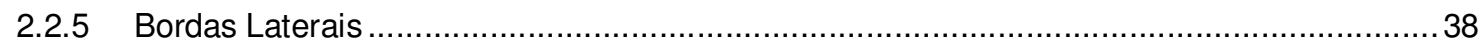

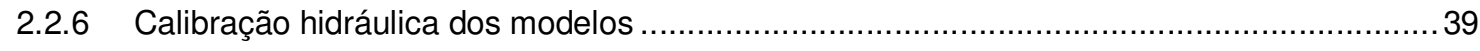

2.3 Criação do SIAMA - Simulador analógico de manobras não tripuladas .........................41

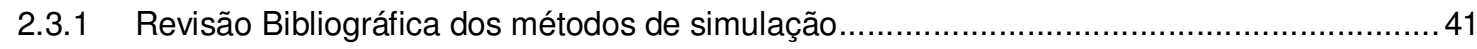

2.3.2 Classificação dos navios existentes no mundo ............................................................... 43

2.3.3 Desenvolvimento da técnica de simulação em modelo físico ...............................................45

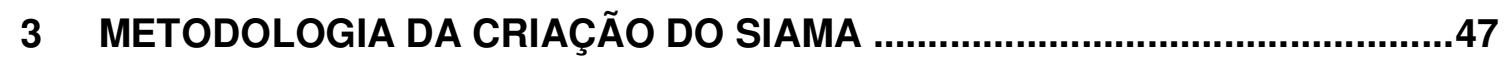

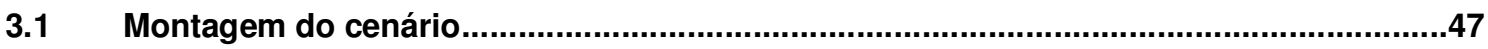

3.2 Modelagem dos navios e superestruturas ....................................................................

3.3 Simulação e calibração dos rebocadores portuários .....................................................52 
3.4 Calibração do sistema de propulsão e leme dos navios .54

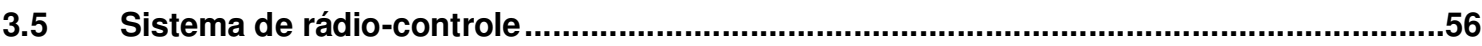

3.6 Visualização da manobra para controle a distância ....................................................58

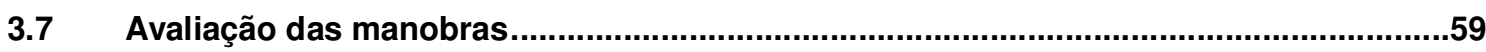

\section{RESULTADOS E GANHOS OBTIDOS NA SIMULAÇÃO DE MANOBRAS DE

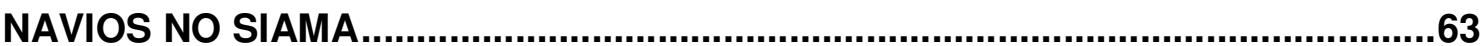

4.1 Terminal Portuário da ALUMAR

4.1.1 Avaliação de manobras visando aumento da janela operacional do Terminal ....................65

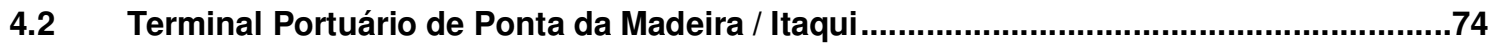

4.2.1 Avaliação de situações de desatracação de emergência nos Píeres I e III ...........................75

4.2.2 Estudo das condições de manobras de navios no projetado Cais 108 da EMAP .................79

4.2.3 Aprovação da ampliação do Píer III para receber dois navios Capesizes ............................. 84

4.2.4 Avaliação de manobras com navios ULOCs no projetado Píer IV .....................................87

4.2.5 Estudo de manobras para o Pólo Siderúrgico de São Luiz .................................................91

4.2.6 Aumento da janela operacional do Terminal de 6 para 16 hs diárias ..................................94

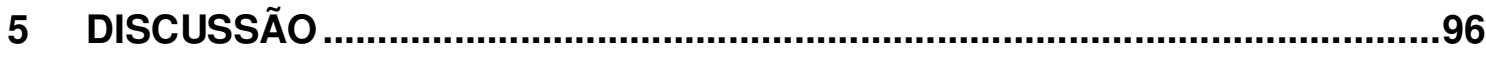

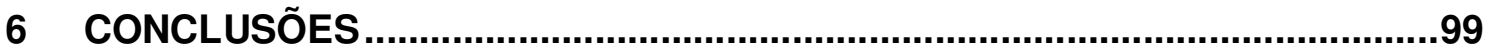

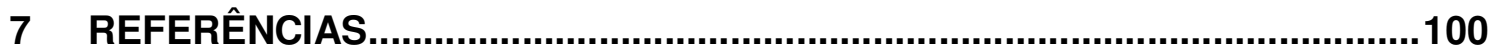




\section{INTRODUÇÃO}

\subsection{Conceituação}

O crescente aumento da frota mundial de navios (ver Tabela ), aliado à evolução tecnológica empregada na construção das embarcações, que vêm sendo construídas com dimensões cada vez maiores, visando aumento na capacidade de embarque, interferem nas condições de manobrabilidade ${ }^{1}$ e segurança da navegação dentro dos portos, e por conseqüência, do confinamento dos espaços e do aumento da movimentação de navios (HENSEN, 1997).

Tabela 1 - Evolução da frota de navios porta-contêineres

\begin{tabular}{|l|c|c|c|c|}
\hline \multirow{2}{*}{ Gerações } & \multirow{2}{*}{ Ano } & \multicolumn{3}{|c|}{ Dimensões } \\
\cline { 3 - 5 } & & Comprimento $(\mathrm{m})$ & Boca $(\mathrm{m})$ & Calado $(\mathrm{m})$ \\
\hline 1'a Geração & 1960 & 200 & 25 & 10 \\
\hline 2a Geração & 1970 & 215 & 25 & 11 \\
\hline 3a Geração & 1985 & 290 & 32 & 12 \\
\hline 4a Geração & 1987 & 305 & 42 & 14 \\
\hline 5a Geração & 2000 & 335 & 46 & 15 \\
\hline 6a Geração & 2007 & 400 & 57 & 16 \\
\hline
\end{tabular}

Desta forma, revela-se premente a necessidade de se planejar métodos eficientes para determinação dos limites de segurança na manobrabilidade e governo ${ }^{2}$ dos navios que operam nos terminais, contemplando os diversos tamanhos e tipos de embarcações envolvidas nas operações, a fim de serem evitados futuros acidentes devido à falta de conhecimento em operações ainda não realizadas (BLAAUW, 1981; BOLATTI, 1988 e VRIES, 1990).

A simulação do comportamento de navios em manobras na escala real é indispensável para distinguir os fenômenos mais relevantes e analisar os resultados com uso de técnicas de avaliação, entretanto em escala real não é possível variar as condições de uma maneira sistemática, somente podendo ser realizadas dentro das

\footnotetext{
1 Manobrabilidade: Capacidade de agilidade da embarcação, com uso dos recursos do leme e propulsor.

${ }^{2}$ Governo: Capacidade de manutenção do rumo da embarcação em função da forma do casco e do uso do leme
} 
condições existentes e os riscos envolvidos não permitem a realização de manobras aparentemente mais difíceis (BRIGGS ET AL, 2006 e PIANC, 1997).

Em 1992 a Área de Hidráulica Marítima do Laboratório de Hidráulica da Escola Politécnica da Universidade de São Paulo - LHEPUSP - tornou-se pioneira no Brasil na simulação interativa em modelos físicos, com participação de Pilotos reais, nas manobras de atracação e desatracação portuárias com navios rádio-controlados, calibrados com as provas de mar das embarcações e de seus rebocadores.

Desde então, o aprimoramento da metodologia tem-se constituído em consagrada ferramenta de planejamento operacional portuário e de segurança da navegação, através do treinamento de Práticos, Mestres de rebocadores e Operadores portuários. Nestes 18 anos, mais de 1.300 manobras já foram executadas por 13 diferentes Práticos, acompanhadas pelos representantes da Autoridade Marítima (Capitania dos Portos) e demais técnicos envolvidos, tendo sido convenientemente registradas e avaliadas por questionário próprio.

A técnica de simulação de tráfego e manobras de navios com a utilização de simuladores analógicos de manobras, rádio-controladas por Pilotos reais, aplicados em modelos físicos, consiste em uma das ferramentas utilizadas para o planejamento das operações portuárias.

Seja qual for a técnica de avaliação utilizada, a opinião dos especialistas deve ser aferida, sejam consultores da área de navegação ou Pilotos. Estes últimos, quando Práticos locais, detêm importante conhecimento geral de condução de diferentes navios nas mais diversas condições ambientais. Esta experiência e conhecimento devem ser convenientemente sintetizados, considerando o Piloto como um tomador de decisão com múltiplo critério de escolha, balanceado pelos fatores relevantes envolvidos, visando a melhor alternativa dentre as executadas (GONÇALVES, 2005). 


\subsection{Objetivo}

O objetivo deste trabalho é o de avaliar criticamente os resultados da técnica de simulação de manobras e tráfego, com a utilização de navios rádio-controlados por Pilotos reais, aplicados em modelos hidráulicos físicos, demonstrando-se sua concepção, além de resultados e ganhos obtidos em estudos de casos de três diferentes portos brasileiros existentes, correspondendo a estudos de manobras e acessibilidade em 14 berços de atracação para navios entre 55.000 e 575.000 tpb. 


\subsection{Justificativa}

A correta modelação da hidrodinâmica do comportamento náutico, de manobra e governo do navio, num complexo contorno geométrico e hidrodinâmico é de fundamental importância para que se tenha fidelidade ao comportamento real.

Existem dois tipos de técnicas empregadas na simulação de tráfego e manobras de navios:

- Modelação Matemática (piloto automático ou Piloto real)

- Modelação Física (Piloto embarcado ou sistema rádio-controlado)

O nível de precisão, fidelidade da trajetória e velocidade do movimento, desenvolvidos nos simuladores, são indispensáveis na representação fiel do comportamento do navio durante as manobras, sendo atualmente debatidos dentro dos estudos da modelagem hidrodinâmica e simulação naval (GONÇALVES, 2005).

Como proposta de trabalho, pretende-se demonstrar que a técnica de simulação de atracação e desatracação de navios com uso de simulador analógico de manobras não tripuladas, empregado em modelos físicos, constitui-se numa ferramenta validada e consagrada na otimização de projetos e operações portuárias, enfatizando-se resultados obtidos com a exposição de estudos de casos.

Será abordada também a metodologia de construção do simulador, englobando os critérios de semelhança hidrodinâmica, sistemas de alimentação e restituição, além da calibração hidráulica dos componentes do simulador. 


\section{REVISÃO BIBLIOGRÁFICA}

\subsection{Modelo Reduzido}

Todo projeto de Engenharia necessita da previsão do comportamento de um sistema a ser construído pelo homem, ou de um sistema natural com o qual ele vai interferir. $\mathrm{Na}$ maioria dos casos, pode-se dizer que $\mathrm{o}$ ato de projetar se confunde com $\mathrm{o}$ ato de prever o comportamento do sistema que se vai realizar.

O Método de Previsão consiste em recorrer a observações efetuadas em outro sistema, que se comporte de modo semelhante ao sistema cujo comportamento se quer prever, mas que apresente menores dimensões, no qual seja mais fácil introduzir modificações, ou variar sob controle os valores das grandezas a serem consideradas. Chama-se protótipo o sistema real cujo comportamento se quer prever. O modelo é o sistema a partir do qual se efetuam as previsões válidas para fins de engenharia.

Comportar-se "de modo semelhante" significa que:

- O mesmo fenômeno, pondo em jogo as mesmas grandezas regidas pela lei física, se passa nos dois sistemas considerados: o real e o modelo;

- Para cada categoria de grandeza existem relações constantes, bem conhecidas e independentes dos valores absolutos da grandeza em questão, entre os valores nos modelos e os valores que ocorrerão no real.

A Teoria da Semelhança é o conjunto dos princípios a serem obedecidos a fim de projetar, construir, operar e interpretar os sistemas (modelos) a partir dos quais se deseja prever o comportamento de outros sistemas (protótipos). Tal teoria comporta dois outros objetivos além do já citado:

1) Estabelecer as relações de transferência entre modelos e protótipos; 
2) Estabelecer o tipo de relação entre as diversas grandezas intervenientes em qualquer fenômeno físico, a fim de poder pesquisar sistematicamente os dados mais significativos.

A palavra modelo é usada como sinônimo do esquema, pois não trabalha-se sobre outro sistema físico e sim sobre uma representação ideal, constituída por um conjunto de conceitos e equações. Concretamente, devem-se formular condições de semelhança relativas à geometria, materiais e forças presentes.

Do ponto de vista da semelhança geométrica, os modelos físicos podem ser: geometricamente semelhantes, geometricamente distorcidos ou analógicos.

Os modelos geometricamente semelhantes são aqueles cuja geometria é determinada pela redução, seguindo a um mesmo fator (escala), de todas as características geométricas do real.

Os modelos geometricamente distorcidos são aqueles que usam diferentes fatores para a redução das características geométricas do real.

Os modelos analógicos são aqueles que não apresentam semelhanças geométricas com os respectivos protótipos e nos quais se passam fenômenos qualitativamente diferentes daqueles que devem ser previstos para o real, mas as equações, que regem os fenômenos no modelo e no real, apresentam a mesma estrutura formal. Assim, a modelagem das manobras de navios utilizada neste estudo constitui-se numa simulação analógica, uma vez que o efeito físico do auxílio de rebocadores é conseguido pelo empuxo de ventiladores entubados fixados no casco do modelo, previamente convenientemente calibrados. Além disso, a manobra não é executada por Piloto embarcado efetivamente.

Para avaliação de problemas em que se efetuam observações sobre outro fenômeno físico, de menores dimensões que o sistema cujo comportamento se quer prever, mas de comportamento semelhante, é chamado de modelo reduzido. 
Chama-se de escala a razão entre cada valor que uma dada grandeza assume no modelo e o valor correspondente que a mesma grandeza assume no real. Para assegurar os aspectos qualitativos e quantitativos de semelhança, entre o sistema modelo e o sistema protótipo, as escalas das diferentes grandezas precisam guardar entre si certas relações.

Ao deduzirem-se valores de escalas a partir das igualdades dos números adimensionais, precisa-se estar alerta para não sair dos limites de validade das leis físicas.

\subsubsection{Escolha da escala}

A fim de obedecer a uma semelhança integral é necessário obedecer à igualdade de todos os números adimensionais entre o modelo e o real, sendo que se atinge esta condição apenas em modelos na escala 1:1.

A construção de um modelo implica não só em fatores de imposição da semelhança das grandezas de maior importância atuando no escoamento, mas também em fatores econômicos no tamanho de sua construção, envolvendo custos de materiais, mão de obra e equipamentos. Desta forma busca-se sempre a escala geométrica mais adequada também do ponto de vista econômico.

Os números adimensionais que normalmente são utilizados para estudo de escoamento dos fluídos são:

a) Número de Euler:

$$
E u=\frac{N_{n}}{\rho v^{2}}(1)
$$


b) Número de Froude:

$$
F_{r}=\frac{v}{\sqrt{g} \cdot l}(2)
$$

c) Número de Reynolds:

$$
R e=\frac{v l_{e} f}{\mu}(3)
$$

d) Número de Weber:

$$
W e=\frac{v^{2}, \rho, l}{\sigma}(4)
$$

e) Número de Mach:

$$
M a=\sqrt{\frac{\rho \cdot v^{2}}{E}}(5)
$$

Nas quais:

$v=$ velocidade média do escoamento $(\mathrm{m} / \mathrm{s}) ;$

$l=$ dimensão linear $(\mathrm{m})$;

$\mu=$ massa específica do fluido $\left(\mathrm{kg} / \mathrm{m}^{3}\right)$;

$\sigma=$ coeficiente de tensão superficial do fluido $(\mathrm{N} / \mathrm{m})$;

$v=$ viscosidade cinemática do fluido $\left(\mathrm{m}^{2} / \mathrm{s}\right)$ 
$g=$ aceleração da gravidade $\left(\mathrm{m} / \mathrm{s}^{2}\right)$;

$E=$ módulo de elasticidade volumétrica $\left(\mathrm{N} / \mathrm{m}^{2}\right)$

O Número de Euler (1) representa a relação entre a força de pressão e a força de inércia, atuantes no escoamento.

O número de Froude (2) é a relação entre as forças de inércia (v) e as forças gravitacionais $(\mathrm{g})$.

O número de Reynolds (3) é a relação entre as forças de inércia, representadas pela velocidade ( $v$ ) e as forças viscosas, representadas pelo coeficiente de viscosidade dinâmica $(\mu)$ do fluido.

O número de Weber (4) relaciona as forças de inércia com as forças de tensão superficial.

O número de Mach (5) relaciona a velocidade do escoamento com a velocidade de propagação do som no meio fluido.

Analisando as expressões acima, é fácil verificar que a igualdade de todos os grupos adimensionais entre dois escoamentos geometricamente semelhantes só é possível para a escala geométrica unitária, pois essa igualdade implica que todas as outras grandezas devem ser proporcionais à escala geométrica. Por exemplo, as viscosidades em dois escoamentos semelhantes deverão ser também proporcionais à escala geométrica, assim como tempo, velocidade e coeficiente de tensão superficial, entre outros. Tal condição é, de modo geral, impossível de ser atendida numa outra escala diferente da unitária, por limitações físicas.

Entretanto, a experiência tem mostrado que, na representação de determinados fenômenos, alguns adimensionais são mais importantes que outros e, dentro de 
alguns critérios, a sua representação pode ser feita através da igualdade de somente um desses grupos adimensionais, sem prejuízo da modelação.

Em um escoamento a superfície livre, o adimensional mais importante é o número de Froude, pois as forças que governam o escoamento são as gravitacionais e as de inércia e, desta forma, adotando-se o número de Froude como sendo o adimensional que rege o fenômeno, tem-se a semelhança Froudeana.

A igualdade dos números de Froude entre dois escoamentos, com escala geométrica diferente da unidade gera a desigualdade de outros grupos adimensionais, ocorrendo os chamados "efeitos de escala". Esses efeitos podem ser desprezados limitando a redução da escala.

Em alguns casos, mesmo com a adoção de escalas avantajadas, a modelação toma-se inexeqüível, seja por razões econômicas, seja pela indisponibilidade de equipamentos ou espaço. Pode-se contornar essa situação representando o fenômeno parcialmente (modelos parciais ou bidimensionais), verificando-se, entretanto a ocorrência dos "efeitos de laboratório", introduzidos por este tipo de representação.

\subsubsection{Critério de semelhança de Froude}

Para a modelação de escoamentos a superfície livre, estabelece-se a igualdade entre os números de Froude do modelo e do real.

Esta condição, por si só, estabelece as relações de extrapolação para o real, das diversas grandezas medidas no modelo.

Fazendo-se a igualdade entre os números de Froude do modelo e do real, tem-se: 


$$
\frac{V_{m}}{\sqrt{g y_{m}}}=\frac{V_{p}}{\sqrt{g y_{p}}}(6)
$$

Sendo $\lambda$ a escala geométrica:

$$
\lambda=\frac{\Sigma_{m}}{L_{p}}(7)
$$

Resultam as seguintes escalas:

Escala de velocidades:

$$
\lambda^{1 / 2}=\frac{v_{m}}{v_{p}}(8)
$$

Escala de pressões:

$$
\lambda=\frac{p_{m}}{P_{p}}(9)
$$

Escala de tempos:

$$
\lambda^{1 / 2}=\frac{T_{m p}}{T_{p}}(10)
$$

Escala de vazões:

$$
\lambda^{5 / 2}=\frac{Q_{n 2}}{Q_{y}}(10)
$$

Os sub-índices " $p$ " e " $m$ " referem-se ao protótipo e ao modelo, respectivamente, e "L" é uma dimensão característica. 
A Escala pode ser definida como uma constante de proporcionalidade que relaciona as características entre dois escoamentos. Essas escalas devem atender condições físicas denominadas Critérios de Semelhança.

\subsubsection{Efeitos de escala}

Os efeitos de escala surgem da impossibilidade de representar em escala todas as características do escoamento, porque não se dispõe de um fluido com viscosidade, massa específica e tensão superficial que satisfaçam simultaneamente todas as leis de semelhança requeridas. Desta forma, se reduzem às dimensões dos contornos sólidos, mas não se reduz a viscosidade, a tensão superficial e a massa específica do fluido; portanto chamamos efeitos de escala os efeitos das forças que atuarão diferentemente no modelo e no real. Sua redução é conseguida quando a importância das forças de efeitos não igualados for desprezível, tanto no modelo quanto no real.

Em qualquer categoria de casos, chama-se efeito escala o erro contido nas previsões do modelo, em conseqüência do fato de não ser possível a semelhança simultânea para todos os tipos de força.

Os efeitos de escala representam o resultado do tratamento impróprio de uma ou mais variáveis das quais as quantidades a serem medidas são dependentes. Para o caso de semelhança de escoamentos com superfície livre, tratadas seguindo o critério de semelhança de Froude, os principais efeitos de escalas são causados devidos à ação da viscosidade e da tensão superficial.

Os regimes laminar, turbulento e de transição, tanto para escoamentos em canais, como para escoamentos em condutos podem ser expressos por um diagrama que relaciona o número de Reynolds $(\mathrm{Re})$ com um fator de resistência (f). Este fator de resistência é um coeficiente de proporcionalidade introduzido na fórmula de Darcy- 
Weisbach, desenvolvida para o cálculo da perda de carga (hp) em condutos forçados (CHOW, 1959):

$$
h_{p}=f \cdot \frac{L}{d} \cdot \frac{v^{2}}{2, g}
$$

Além de depender da velocidade $(v)$ e do diâmetro do conduto $(d)$, o fator de resistência engloba os efeitos viscosos e os efeitos da rugosidade relativa presentes no escoamento, o que permite dizer que o fator de resistência é uma função do número de Reynolds do escoamento e da rugosidade relativa (que é a razão entre a rugosidade equivalente "k" e o diâmetro do conduto). Nos escoamentos semelhantes dinamicamente, as perdas de carga devem ser similares e o fator de resistência deve ser o mesmo no modelo e no real.

O diagrama de Moody (mostrado na Figura 1) apresenta a plotagem do fator de resistência de uma série de experiências com condutos lisos e rugosos em função do número de Reynolds e das rugosidades relativas.

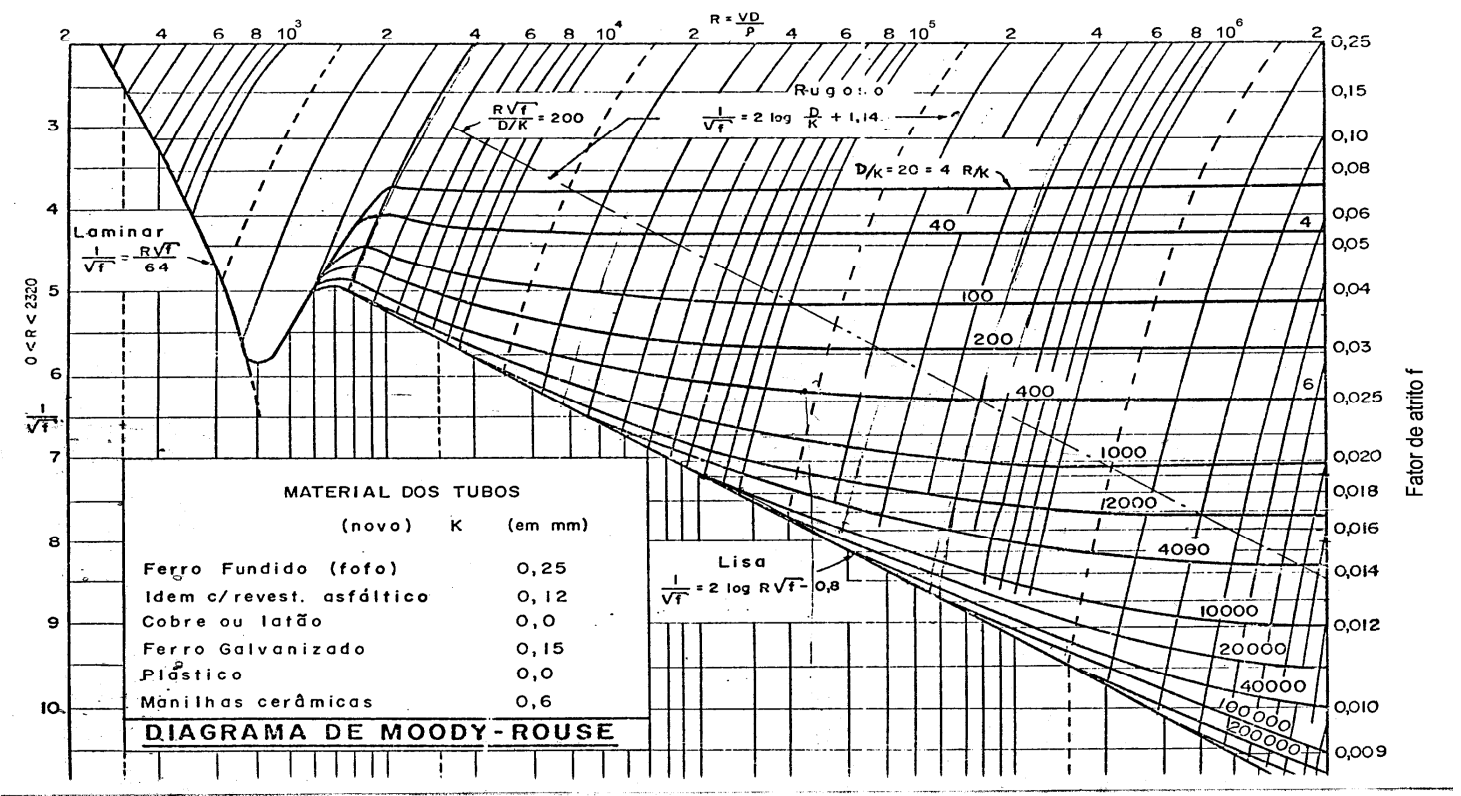

Figura 1: Diagrama de Moody-Rouse (fonte: VENNARD e STREETER, 1978) 
Analisando o diagrama de Moody-Rouse nota-se que:

a) O regime de escoamento varia com o aumento do número de Reynolds;

b) A transição entre os regimes laminar e turbulento ocorre de forma pouco definida, onde a previsão do fator de resistência é imprecisa e depende do número de Reynolds, da rugosidade relativa e de características do fluxo em instantes de tempos anteriores;

c) Para escoamentos laminares, o número de Reynolds influencia significativamente a determinação do fator de resistência, enquanto a rugosidade relativa não é significativa;

d) Para o caso de escoamentos turbulentos, as curvas para cada rugosidade relativa são distintas e tendem a tornarem-se horizontais para crescentes números de Reynolds, mostrando a não importância da viscosidade no escoamento, chegando ao ponto da situação onde o fator de resistência só depende da rugosidade relativa (escoamento turbulento rugoso).

Para o escoamento em canais, o cálculo da variação de energia é realizado através da fórmula de Manning (resistência ao escoamento):

$$
Q=\frac{1}{n} \cdot A \cdot R h^{2 / 3} \cdot \sqrt{S}(13)
$$

Na qual:

Q: Vazão;

$n$ : Coeficiente de Manning;

A: Área da seção transversal;

Rh: Raio Hidráulico da seção transversal;

$S$ : Declividade da linha de energia. 
A interpretação do diagrama de Moody-Rouse pode ser aplicada para escoamentos em condutos e escoamentos com superfície livre.

O coeficiente de Manning e o fator de resistência podem ser relacionados pela equação abaixo:

$$
n=\sqrt{\frac{f}{8 g}} \cdot R h^{1 / 16}(14)
$$

e que pode ser deduzida através das equações de perdas de carga em canais e em condutos, fazendo o diâmetro do conduto equivalente a $4 R h$ (HENDERSON,1966).

Segundo HENDERSON (1966), embora as condições de contorno em canais e em condutos possam ser bastante diferentes, aparentemente os efeitos da forma da seção transversal são pequenos.

Se os escoamentos do modelo e do real estiverem no regime turbulento rugoso, o número de Reynolds não terá interferência no fator de resistência e a existência dos efeitos de escala deve ser creditada à falta de semelhança geométrica da rugosidade das paredes. Se o escoamento no modelo apresentar números de Reynolds não tão elevados a ponto de ser estabelecido o regime turbulento rugoso, os efeitos viscosos terão maior importância no fator de resistência, interferindo, assim, na semelhança das perdas de carga do escoamento.

Além de diferenças nas variações de energia, o desenvolvimento da camada limite, em modelos e protótipos, pode ser distinto.

Em escoamentos com superfície livre a espessura da camada limite influencia na profundidade do escoamento e, conseqüentemente, na medição das pressões, haja visto que a altura de pressão depende da profundidade do escoamento. Sendo assim, os efeitos de escala entre modelos e protótipos que apresentam regimes de escoamento distintos podem afetar a validade das medições realizadas em modelo, 
e devem ser levados em conta sempre que houver divergências significativas entre os números de Reynolds.

$\mathrm{Na}$ modelagem de Terminais Portuários, além dos efeitos viscosos, a tensão superficial também não é corretamente representada no modelo, uma vez que o número de Weber no modelo não é o mesmo do real.

A reprodução fiel de todos os parâmetros envolvidos em escoamentos com superfície livre possui baixa viabilidade econômica e prática. A opção inadequada do critério de semelhança resulta no aparecimento de efeitos de escala no modelo, prejudicando sua confiabilidade. Estes efeitos são provocados pela discrepância entre os parâmetros adimensionais relevantes na reprodução do escoamento e não respeitados pelo critério escolhido.

Pelo ponto de vista técnico, a escala geométrica deve ser a maior possível, para se evitar que as forças distorcidas pelo critério de semelhança escolhido tornem-se significativas na representação do escoamento. Do ponto de vista econômico, busca-se reproduzir o protótipo na menor escala possível. Assim, procura-se encontrar um equilíbrio entre praticidade, economia e bons resultados, escolhendo a escala geométrica que melhor solucione estes três fatores.

\subsubsection{Escoamento com superfície livre}

Nos escoamentos a superfície livre as principais forças atuantes são a força devido à ação da gravidade e a força devida à ação da viscosidade. A semelhança dinâmica entre dois sistemas que apresentam superfície livre deve obedecer simultaneamente ao critério de semelhança de Froude e ao critério de semelhança de Reynolds; o que limita a escolha da escala geométrica à escolha do fluido a ser utilizado no modelo. Pode-se demonstrar esta situação matematicamente, como segue:

Critério de semelhança de Froude: 


$$
\frac{F r_{m}}{F r_{p}}=1 \rightarrow \frac{F r_{m}}{F r_{p}}=\frac{\frac{V_{m}}{\sqrt{g_{m} \cdot y_{m}}}}{\frac{V_{p}}{\sqrt{g_{p} \cdot \gamma_{p}}}}=1
$$

$$
\begin{gathered}
\text { Sendo } \frac{v_{m}}{v_{p}}=\lambda_{v}: \frac{g_{n}}{s_{p}}=\lambda_{g} \text { e } \frac{L_{m}}{L_{p}}=\lambda \text {, então: } \\
\lambda_{v}=\sqrt{\lambda_{g} \cdot \lambda} \text { (16) }
\end{gathered}
$$

Critério de semelhança de Reynolds:

$$
\frac{R e_{m}}{R e_{p}}=1 \rightarrow \frac{R e_{m}}{R e_{p}}=\frac{\frac{V_{m} \cdot L_{m}}{v_{m}}}{\frac{V_{p} \cdot I_{s}}{v_{p}}}=1
$$

$$
\begin{gathered}
\text { Sendo } \frac{v_{m}}{v_{p}}=\lambda_{v}: \frac{v_{m}}{v_{p}}=\lambda_{v} e \frac{L_{m}}{L_{p}}=\lambda, \text { então: } \\
\lambda_{v}=\frac{\lambda_{v}}{\lambda}
\end{gathered}
$$

Igualando-se (16) e (18), tem-se:

$$
\lambda_{v}=\sqrt{\lambda_{g} \cdot \lambda} \rightarrow \lambda_{v}{ }^{2}=\lambda_{g} \cdot \lambda^{3}
$$


As condições gravitacionais são as mesmas para o modelo e para o real e o fator gravitacional toma-se igual a 1; desta forma as viscosidades cinemáticas dos dois fluidos (real e modelo) devem obedecer à relação:

$$
\lambda-\lambda_{v}^{2 / 0}
$$

No estudo de Terminais Portuários, o fluido de protótipo é a água salgada, com viscosidade cinemática de valor aproximado de $1,095^{\star} 10^{-6} \mathrm{~m}^{2} / \mathrm{s}$, o que torna difícil satisfazer a equação (20) para uma escala geométrica econômica. Desta forma, utilizando-se a água como fluido de modelo, deve-se eliminar algum critério do sistema de condições de semelhança.

O estudo de Terminais Portuários envolve o escoamento de água sob o efeito de correntes, sendo comum que esta situação de escoamento apresente altos números de Reynolds, pois a água salgada apresenta uma viscosidade muito baixa. $\mathrm{A}$ rugosidade das margens e costas geralmente é alta. Aliando-se estes dois últimos fatos (rugosidade das margens e costas e viscosidade do fluido do modelo), pode-se dizer que o estudo de Terminais Portuários normalmente envolve escoamentos em regime turbulento rugoso, onde os efeitos viscosos apresentam uma influência menor do que os efeitos da gravidade. Sendo assim, o critério de semelhança usualmente eliminado nestes casos é a semelhança de Reynolds e a desigualdade desta semelhança acarreta a não semelhança integral dos dois sistemas, sendo assim a principal responsável pelas diferenças observadas entre medições de modelo e protótipo.

\subsubsection{Simplificação na representação}

Toda representação tem implícita uma simplificação da realidade, na medida em que não são reproduzidos pequenos detalhes presentes no real. As causas desta simplificação são: 
a) As informações iniciais já apresentam a realidade com simplificações, portanto não se conhecem os detalhes. Esta simplificação é resultante das incertezas presentes nas informações iniciais;

b) A técnica empregada na representação implica em simplificações, pois na representação de um relevo, reproduzem-se seções ou curvas de nível e a união destas curvas por interpolação é uma simplificação da realidade;

c) Detalhes que no real não alteram significativamente o escoamento na região de estudo, o que não justifica sua representação. A exclusão de elementos menores simplificando a execução é prática recomendável no que diz respeito à economia de tempo e custos do estudo, porém pequenos detalhes como cantos, reentrâncias podem alterar as correntes nestes locais e algumas regiões de estudo podem ser sensíveis a esta alteração, como por exemplo, as regiões de aproximação de fluxo.

\subsubsection{Características dos materiais empregados}

Os materiais empregados em laboratório têm características diferentes daqueles que efetivamente são utilizados no real. Para efeito de representação são importantes características tais como:

a) Facilidade de manuseio tanto para modelação, para certa precisão, como para alterações;

b) Estabilidade durante o estudo;

c) Transparência, quando se deseja visualizar o fenômeno hidráulico em estudo;

d) Disponibilidade do material;

e) Fidelidade das características hidráulicas do material no real. 
Dentre as características dos materiais empregados, destacam-se as que interessam particularmente em termos hidráulicos:

a) Rugosidade, quando for material fixo;

b) Densidade, formato do grão e granulometria, quando for material solto.

Deve-se empregar materiais com rugosidade aproximadamente em escala, preferencialmente menores, devido ao fato da viscosidade do fluido, em um modelo na escala de Froude, ser proporcionalmente maior e a utilização de rugosidades inferiores à rugosidade na escala tendem a diminuir os efeitos de escala devidos à maior viscosidade.

Muitas vezes o material solto no real é de difícil caracterização, tal como o solo lançado em aterros que não tem suas propriedades claramente especificadas, dado o número de parâmetros que alteram estas propriedades. A escolha do material utilizado para esta representação é feita através da observação de comportamentos análogos no modelo e no real. O embricamento e o desgaste provocado pela flutuação de pressão são algumas das características do material de protótipo de difícil representabilidade.

\subsection{A construção dos modelos portuários para os Terminais de Ponta da Madeira - MA, ALUMAR - MA e Ilha Guaíba - RJ}

No modelo de Ponta da Madeira (ver Figura 2) modela-se fisicamente, até o nível de semelhança dinâmica (forças hidrodinâmicas), em escala geométrica não distorcida de 1:170, parte da região da Baía de São Marcos em São Luiz do Maranhão - MA, abrangendo todos os Terminais Portuários nela presentes: Ponta da Madeira (Companhia Vale), Porto de Itaqui (EMAP) e o Terminal Portuário da ALUMAR (Consórcio de Alumínio do Maranhão - conforme Figura 4), permitindo que sejam reproduzidas as correntes de maré e seus efeitos sobre os navios nas condições de 
enchente e vazante para amplitudes de até $7,0 \mathrm{~m}$. O modelo ocupa uma área de aproximadamente $1.000 \mathrm{~m}^{2}$. Por se tratar de uma região naturalmente abrigada de ondas, estas não são representadas no modelo.

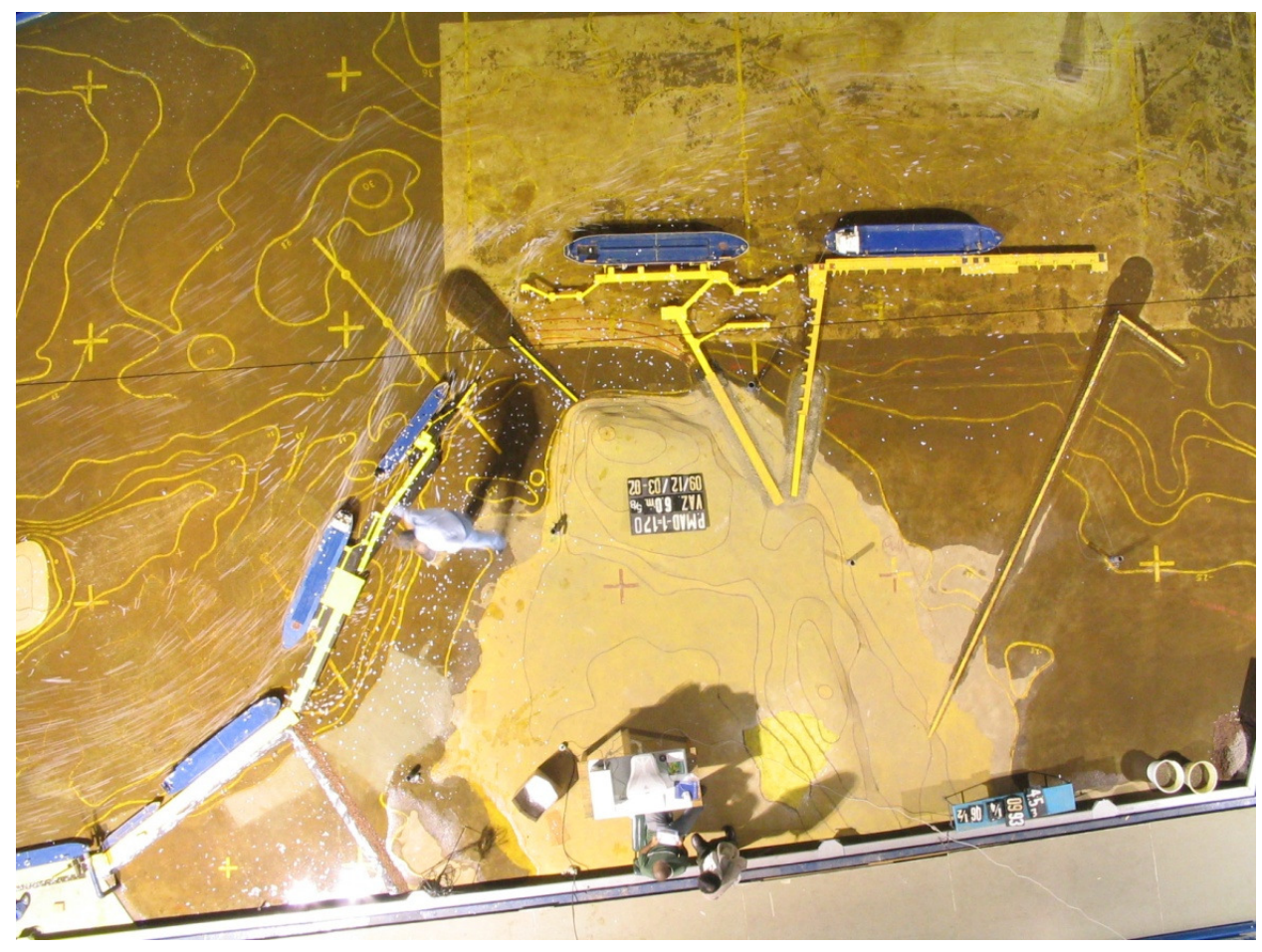

Figura 2: Foto zenital do modelo de Ponta da Madeira (fonte: FCTH, 2000)

O modelo do Terminal Portuário de llha Guaíba (Figura 3) possui também escala geométrica não distorcida de 1:170, ocupa uma área de aproximadamente $900 \mathrm{~m}^{2} \mathrm{e}$ consiste na modelação de parte da Baía de Sepetiba ao sul da Restinga da Marambaia - RJ, onde localiza-se o Terminal. O modelo representa além das correntes de maré, as ondas características da região e seu efeito de forças hidrodinâmicas. 


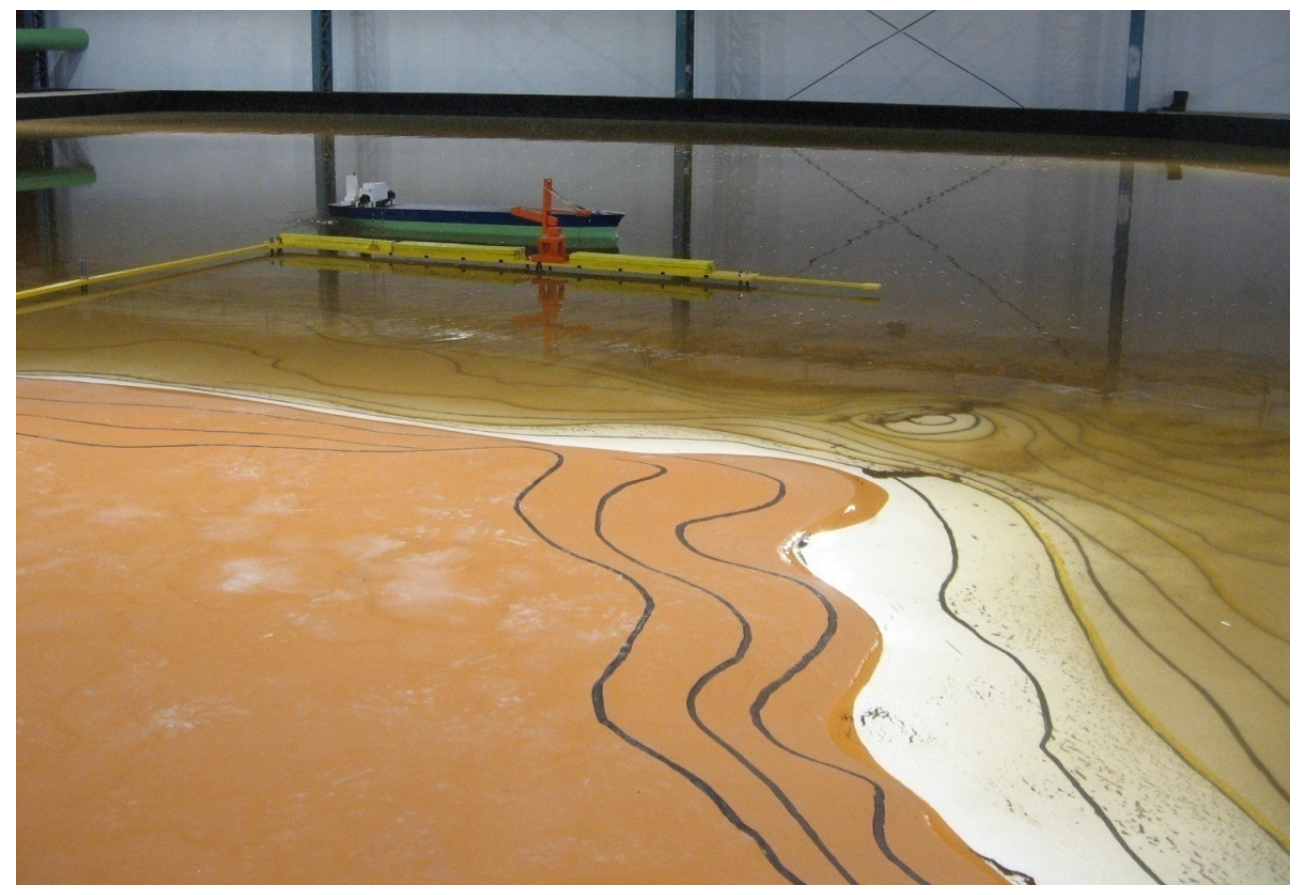

Figura 3: Realização de manobra no modelo físico TIG - Terminal llha Guaíba (fonte: FCTH, 2009)

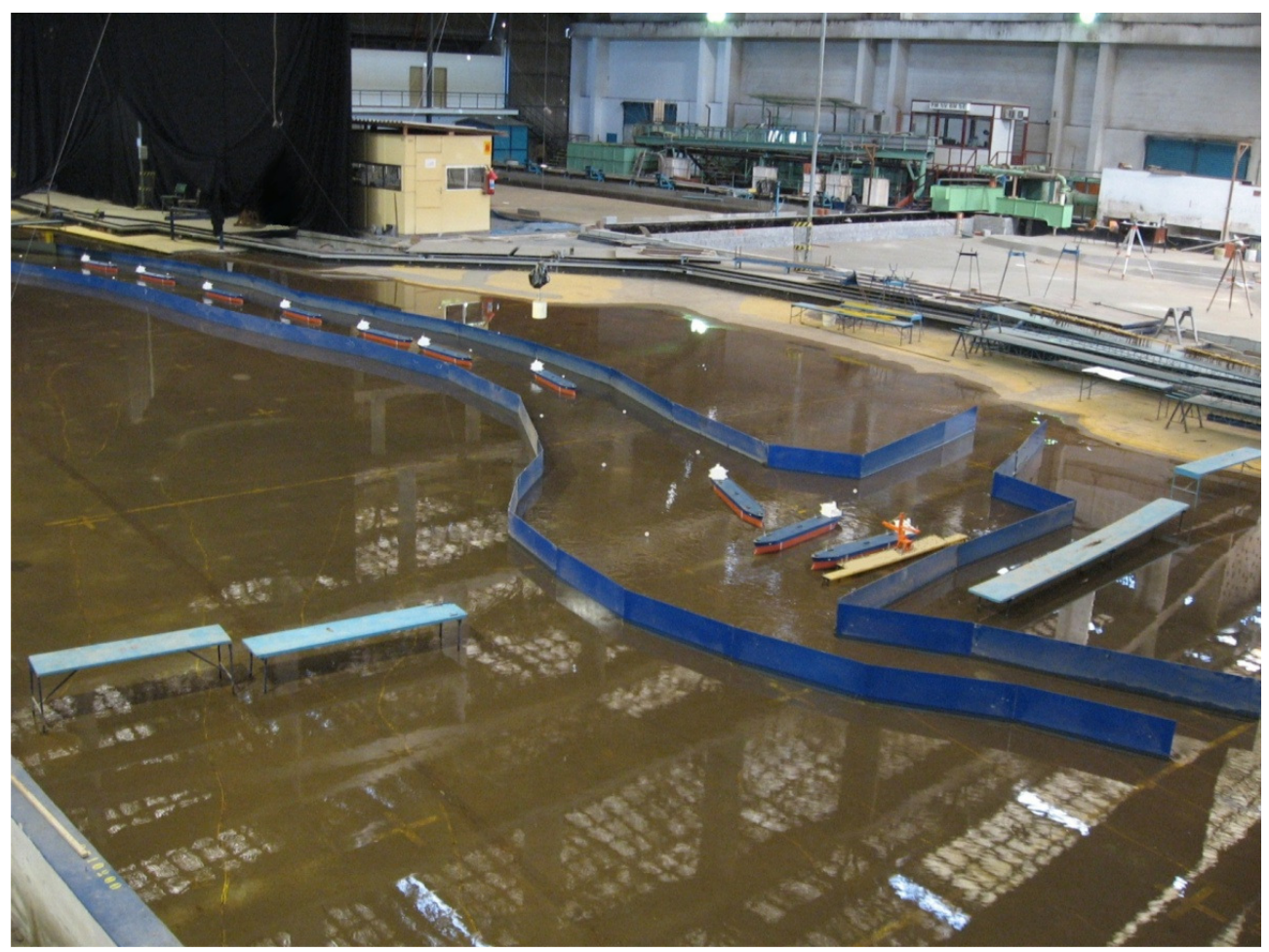

Figura 4: Realização de manobra no modelo do Terminal da ALUMAR (fonte: FCTH, 2008) 


\subsubsection{Construção de modelo}

O método utilizado na técnica de Modelação Física inicia-se com a escolha da região a ser estudada em modelo de uma área do entorno do Terminal Portuário, que deve ser feita de acordo com a escala estudada previamente e da região de maior interesse de estudo. Sendo necessária a representação fiel, nas escalas indicadas, de toda a topografia e topobatimetria da respectiva região.

Definida a região a ser estudada, inicia-se a impermeabilização do piso do local onde será construído o modelo, em seguida constroem-se as paredes limites do modelo em alvenaria de blocos de concreto ou tijolos maciços, assentados com argamassa de cimento e areia (Figura 5), intercaladas a cada 3,00 metros de largura (no máximo) por um pilar de concreto armado e a cada 1,00 metro de altura por uma cinta de amarração de concreto armado, cobertas por um reboco composto de cimento e areia acrescido de impermeabilizante líquido, e em seguida coberto internamente por uma camada de cimento queimado. Concluída a cura do cimento, procede-se a uma nova impermeabilização interna das paredes limites com a utilização de outro impermeabilizante líquido para garantia da estanqueidade do modelo.

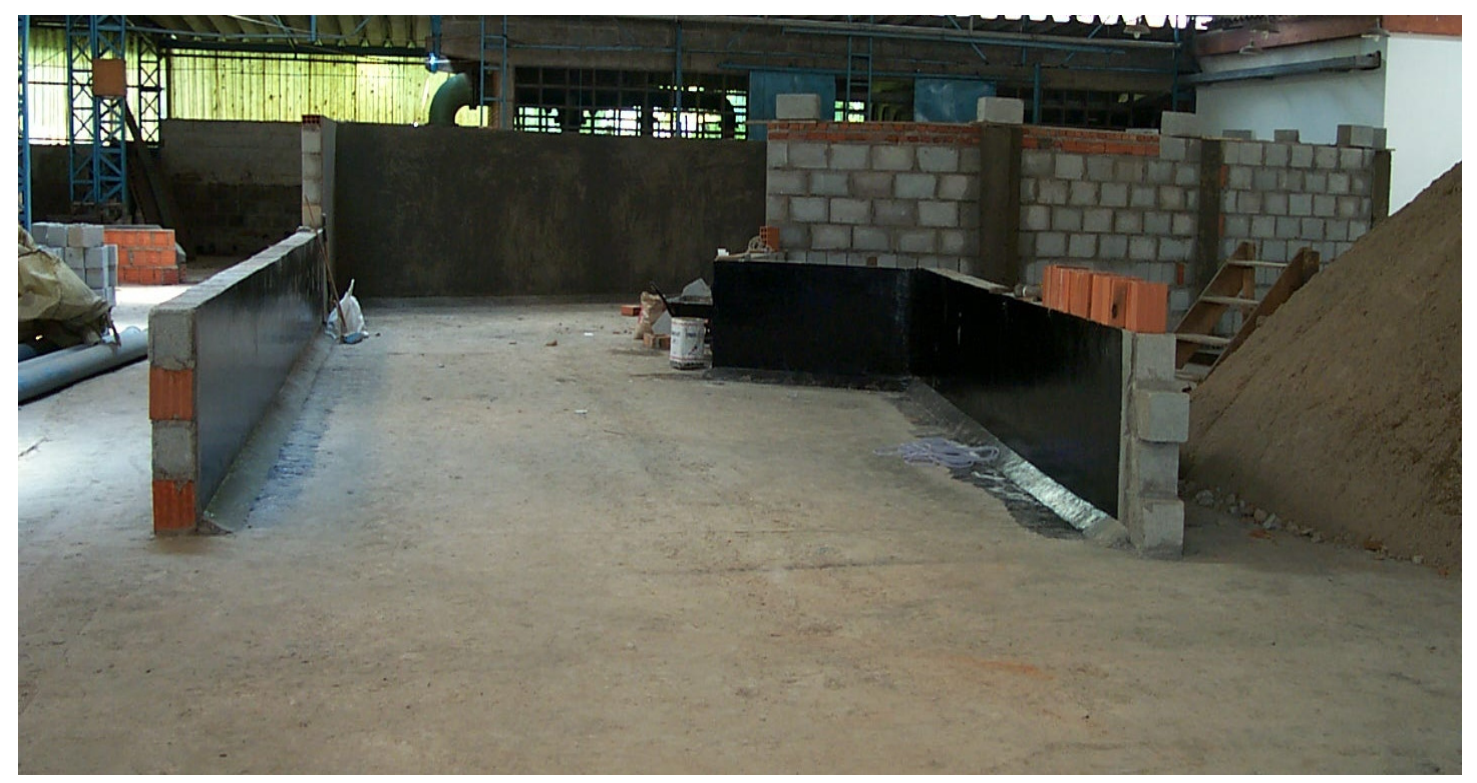

Figura 5: paredes limites do modelo físico na fase construtiva (fonte:FCTH, 2006) 
As paredes laterais de contorno devem ser preferencialmente dispostas de maneira a não interferirem na direção das correntes durante a operação do modelo. Em alguns casos são propositadamente dispostas de maneira a direcionarem as correntes em regiões com presenças de obstáculos ao escoamento, curvaturas naturais, encontro de águas, etc.

Concluída a delimitação da área com paredes limites, inicia-se a etapa de georeferenciamento do modelo com a implantação das coordenadas cartográficas notáveis, que são projetadas no piso e nas laterais do modelo com auxílio de teodolito eletrônico.

O georreferenciamento do modelo é indispensável já que todas as estruturas e obras devem ser materializadas no modelo a partir de suas coordenadas de implantação (Figura 6).

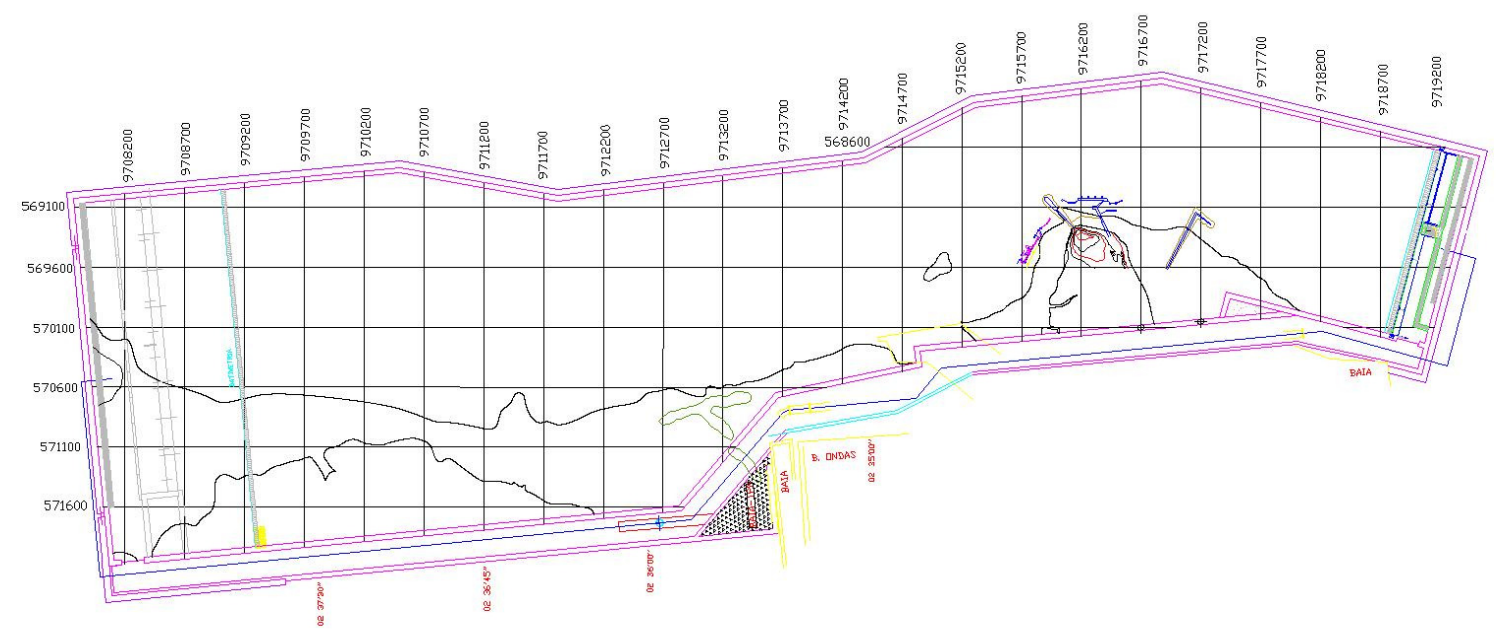

Figura 6: Georeferrenciamento do modelo de Ponta da Madeira (fonte:FCTH, 2009)

Com as coordenadas cartográficas lançadas nas paredes e piso do modelo, procede-se a execução de quadrículas de $1,0 \times 1,0 \mathrm{~m}$, que servirão de referência para a implantação das curvas de nível (batimétricas e topográficas), que são projetadas, em escala, com auxílio de retroprojetor ou projetor eletrônico (Figura 7). 


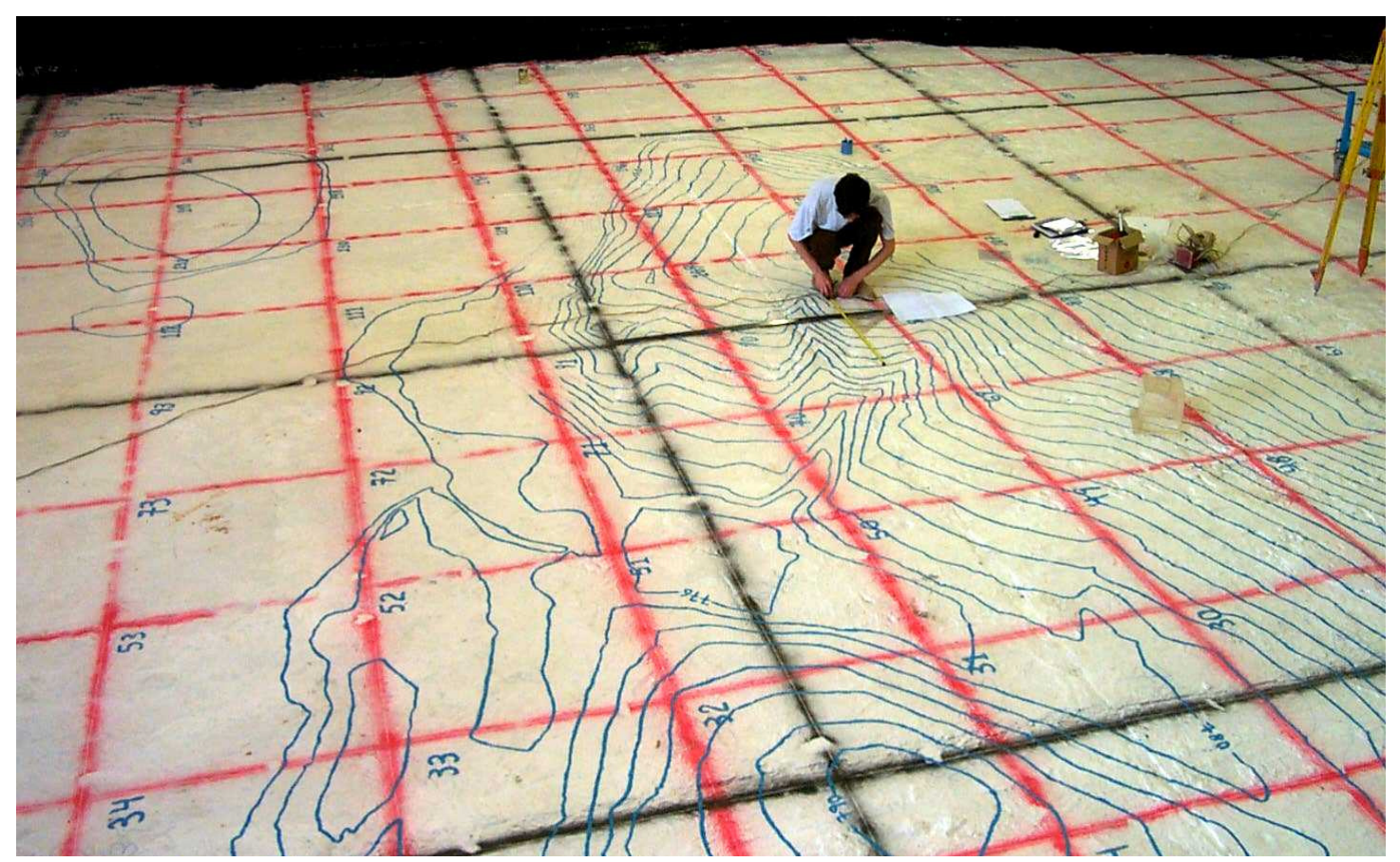

Figura 7: Projeção da batimetria (fonte: FCTH, 2006)

Deve-se cravar, nas proximidades do modelo, RN's (referências de nível) que serão utilizadas como base para o nivelamento de todas as curvas de nível e estruturas implantadas no modelo.

Concluído o lançamento de todas as curvas de nível sobre o piso do modelo, iniciase o processo de nivelamento destas, passando-as da segunda para a terceira dimensão. Nesta etapa é imprescindível o uso de nível óptico, para garantia da precisão das cotas verticais das curvas, que são calculadas a partir do $\mathrm{RN}$ (referência de nível) do modelo.

Sobre cada curva, projetada no piso do modelo, são aprumadas fitas metálicas (com mesmo comprimento, em escala, da curva representada), cuja altura é regulada por meio de pequenos macacos (cursor com regulagem vertical da ordem de $2,0 \mathrm{~cm}$ ) permitindo um perfeito nivelamento. Em seguida essas fitas metálicas são chumbadas em pilaretes em espaçamentos convenientes (Figura 8). 


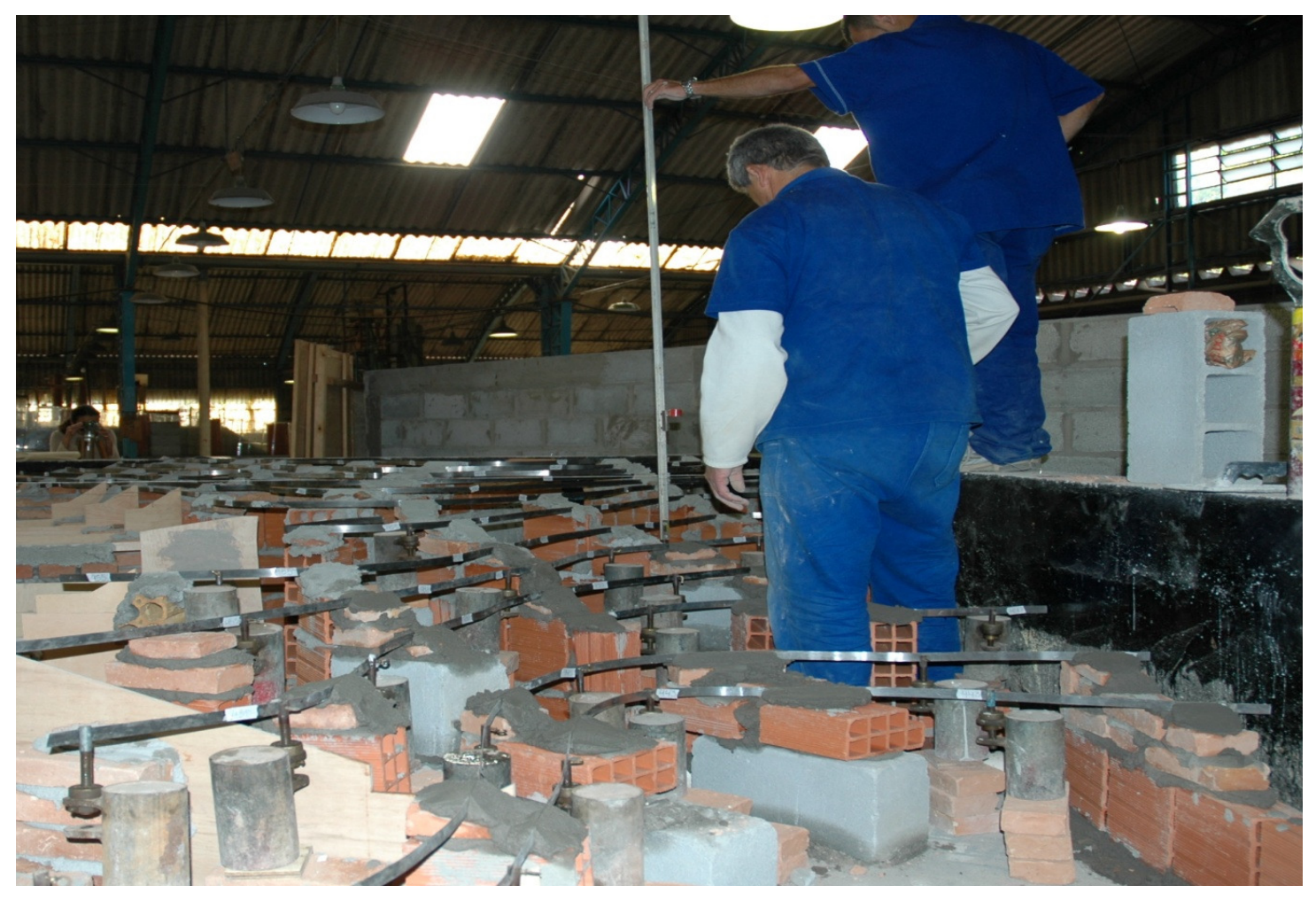

Figura 8: Nivelamento das curvas de nível (fonte: FCTH, 2006)

Após o nivelamento de todas as curvas de nível do modelo, deve-se encher o modelo com areia média lavada até a cobertura parcial das fitas metálicas. Em seguida, encharca-se a areia, deixando abertos os drenos instalados no piso. A areia deve ser compactada com equipamentos apropriados, a fim de se aproximar todos os grãos da areia, eliminado os vazios entre eles, evitando desta forma possível recalques do contra-piso a ser modelado por cima da areia.

Finalizado todo processo de compactação de areia, molda-se com argamassa (espessura da ordem de $1,5 \mathrm{~cm}$ ) as superfícies geradas no encontro de todas as curvas de nível.

A rugosidade do fundo deverá ser ajustada na etapa de calibração hidráulica do modelo. 
Os modelos hidráulicos dos Terminais de Ponta da Madeira, ALUMAR e llha Guaíba são modelos geometricamente não distorcidos, com escala geométrica linear de 1:170, obedecendo à semelhança de Froude e construídos a fundo fixo.

Nos três casos não é representado o movimento real da maré, com acelerações e desacelerações do escoamento e subida e descida do nível d'água, mas modela-se um instante do ciclo da maré em condições de escoamento permanente. Portanto, embora as condições típicas da natureza não sejam modeladas, as condições críticas de máximas correntes de enchente e vazante podem ser reproduzidas. Para tanto existem sistemas de alimentação, modulação, direcionamento do escoamento e regulação de níveis duplicados nas extremidades de montante e jusante.

O circuito de alimentação dos modelos é recirculatório. Constituído por um reservatório inferior, a partir do qual bombas centrífugas recalcam água para um reservatório superior de nível constante, de onde sai a tubulação de alimentação do modelo, dotada de dispositivo medidor de vazão deprimogêneo, cuja água aduzida retorna ao reservatório inferior após atravessar o modelo e cair no canal de restituição. A vazão máxima dos conjuntos de alimentação é de aproximadamente $230 \mathrm{l} / \mathrm{s}$, sendo a faixa normal de operação de 100 a $150 \mathrm{l} / \mathrm{s}$. Para a faixa de vazões ensaiadas o erro na medição de vazão é inferior a 9\% (ver capitulo 2.2 .3 - testes de aferição dos medidores de vazão dos modelos portuários).

\subsubsection{Alimentação dos modelos}

Alimentação do modelo é definida como sendo a entrada de água no modelo. A alimentação ideal seria aquela que fornecesse o escoamento com as características na seção de entrada iguais àquelas encontradas no real.

Para uma representação mais próxima das condições reais de entrada no modelo, são utilizados difusores, fixados na parede da câmara de alimentação do modelo, que distribuem a vazão ao longo da entrada do modelo, além de módulos de PVC 
(Figura 9), distribuídos verticalmente e horizontalmente em caixas de alumínio com dimensões da ordem de $1,0 \mathrm{~m}$ de largura $\times 50 \mathrm{~cm}$ de altura $\times 25 \mathrm{~cm}$ de profundidade, que permitem a obstrução da entrada da água por setores onde, no real, se têm fluxos menores, como por exemplo, presença de ilhas, bancos de areia, obras de abrigo, etc.

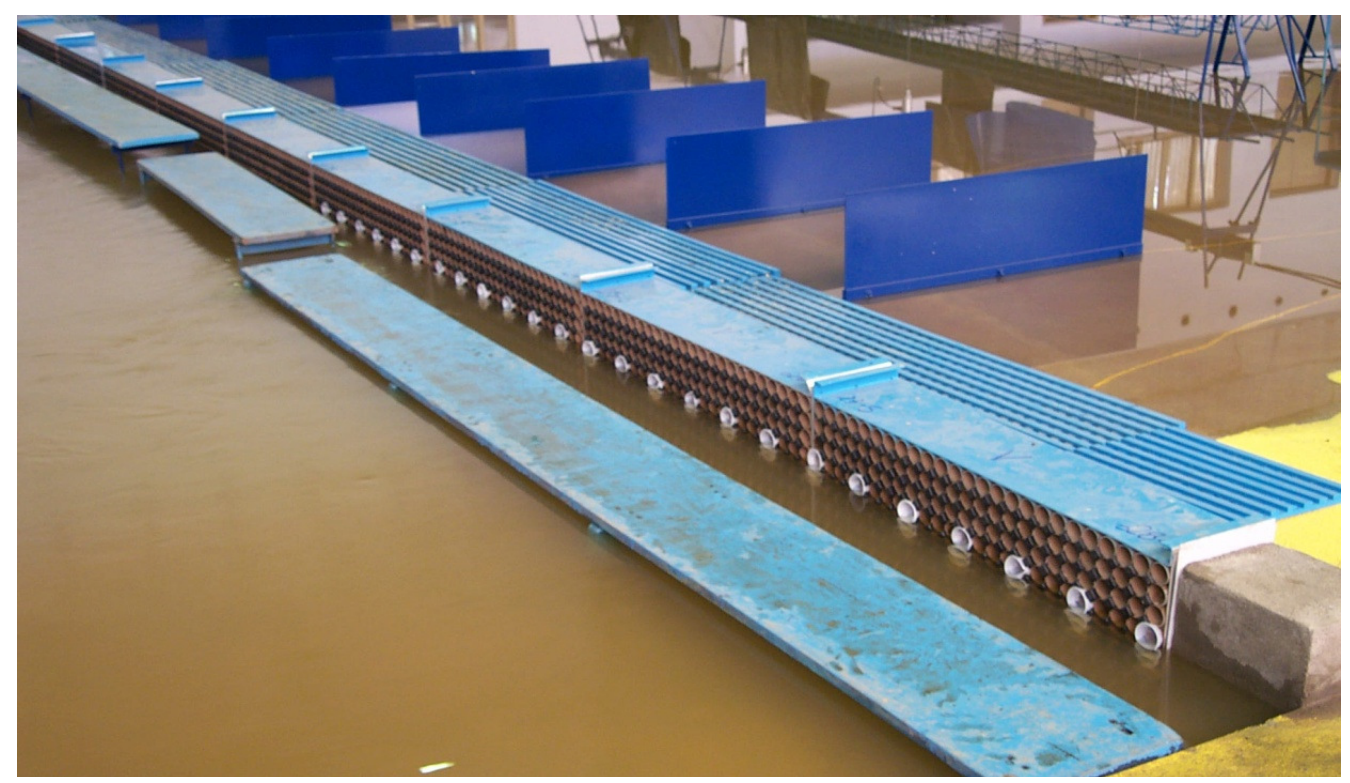

Figura 9: Módulos de PVC (fonte: FCTH, 2004)

Duas ações em conjunto são recomendáveis para a redução dos efeitos de má representação na alimentação:

a) Afastar a parede inicial do modelo, de modo a incluir na representação uma região suficientemente grande permitindo uma boa acomodação do escoamento sobre a batimetria. Esta atitude é muito importante quando existem curvas a montante que possam provocar correntes secundárias, cuja representação é obrigatória para garantir-se a semelhança dos resultados. Particularidades relativamente próximas devem sempre ser incluídas, tais como controles, obras a montante/barlamar e quaisquer outras características que alterem o escoamento a jusante/sotamar, bem como reduzir os efeitos de um escoamento da alimentação não uniforme; 
b) Criar um escoamento na alimentação uniforme, sem correntes secundárias, provocadas pelos dispositivos de alimentação que possam se propagar para o interior do modelo. Normalmente este objetivo é alcançado com a inclusão de difusores e tranqüilizadores que podem ter suas posições alteradas de modo a representarem algumas características do escoamento no real que sejam de conhecimento do laboratório.

Os modelos dos Terminais Portuários de Ponta da Madeira, ALUMAR e llha Guaíba, possuem sistemas de alimentação nas duas extremidades do modelo, tornando-se possível a representação das correntes de enchente a vazante, que possuem direções opostas.

Por se tratarem de modelos com marés estáticas e correntes permanentes, é fundamental que o regime de escoamento do modelo também seja permanente, sem possibilidade de variação de vazão no decorrer dos ensaios. Esta condição é criada com a colocação de calhas de nível constante sobre o reservatório superior, que deverá ser sempre alimentado por uma vazão superior à vazão de saída para o modelo, para que haja sempre o transbordamento de água sobre as calhas.

A partir do momento em que a vazão de entrada no modelo é regulada através da manobra de registros, esta passa a ser constante ao longo do tempo, já que não haverá variação da carga (distância do eixo da tubulação até o nível da água no reservatório superior) nem de área de passagem da água (controlada pelos registros).

A vazão é regulada com o uso de medidores deprimogêneos, como tubo-dall, Venturi ou diafragma (como ilustrado na Figura 10), ligados a quadros de manômetros água-ar ou água-mercúrio, com precisão de leitura de 1,0 mm. 


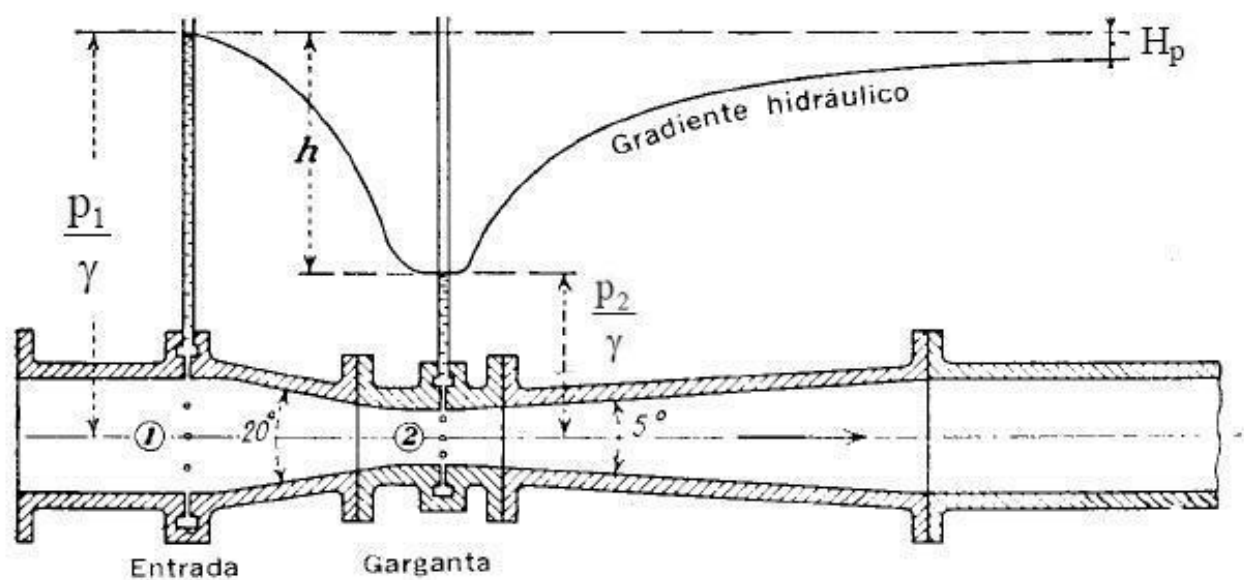

Figura 10: Esquema do medidor Venturi (fonte: American Society of Mechanical Engineers, 1977)

\subsubsection{Testes de aferição dos medidores de vazão dos modelos portuários}

Alterações indesejadas nas condições hidráulicas do modelo (classificadas como efeitos de variabilidade), provocadas por danos ao modelo, deterioração e desgaste dos materiais e equipamentos empregados e criação de depósitos que alterem a rugosidade ou mesmo a geometria dos contornos, podem comprometer significativamente a qualidade dos ensaios. Salvo o caso de danos no modelo, todas as demais causas são progressivas, com efeitos que tendem a se agravar continuamente.

Uma situação particularmente crítica se refere à variabilidade dos instrumentos de medição permanentes instalados no modelo. A deformação de um suporte de uma ponta limnimétrica, o depósito de materiais no interior de um medidor de vazão, o entupimento de uma tomada piezométrica, ou a deformação geométrica de um quadro de manômetros, podem afetar os resultados a ponto de invalidar campanhas inteiras.

Esses efeitos progressivos provocam 0 aparecimento de erros sistemáticos variáveis. É difícil a detecção deste tipo de variação, só tornando-se evidente quando atinge magnitudes comprometedoras. Quando a alteração ocorre em um 
instante definido, como o caso de danos, rompimentos ou obstruções, o efeito é um erro sistemático constante. Também neste caso, o problema apenas evidencia-se quando as magnitudes são comprometedoras.

A redução destes tipos de efeitos é conseguida com inspeções e manutenções periódicas do modelo, e a recalibração sistemática dos instrumentos permanentes (ZAIDAN, 1994).

Como exemplificação destas importantes verificações sistemáticas, durante o mês de novembro de 2009 , foram realizados testes práticos visando à verificação das condições de calibração dos medidores deprimogêneos utilizados para o ajuste das vazões nos modelos dos Terminais Portuários de Ponta da Madeira e da llha Guaíba.

Utilizando-se como referência um medidor de vazão ultrassônico com registro digital, acoplado externamente à tubulação, a vazão registrada em seu visor foi confrontada com a vazão indicada pelo manômetro diferencial instalado, pertencente ao medidor deprimogêneo do modelo.

O objetivo principal dos testes foi avaliar e quantificar possíveis variações da vazão ao longo do tempo (efeitos de variabilidade) para uma condição constante de alimentação, bem como avaliar possíveis variações por faixas de vazões.

Foram testadas as condições de enchente e vazante dos dois modelos.

Inicialmente os modelos foram alimentados com uma vazão intermediária em relação às faixas de vazões de trabalho do medidor. De dezoito em dezoito minutos eram feitas leituras do $\Delta \mathrm{h}$ no manômetro diferencial de pressão do medidor do modelo, verificando-se sua correspondente vazão, registrada na tabela de aferição do mesmo. Simultaneamente a vazão também era lida no display do medidor ultrassônico, registrando ambas em uma tabela, por mais de uma hora.

Nota : Perímetro do tubo Ǿ $=1.12 \mathrm{~mm}$, parede $14 \mathrm{~mm}, \varnothing \mathrm{i}=350 \mathrm{~mm}, \varnothing \dot{e}=378 \mathrm{~mm}$ 
Tabela 2: Terminal Ponta da Madeira - ENCHENTE (vazão

\begin{tabular}{|c|c|c|c|c|}
\hline \multicolumn{2}{|c|}{ Leitura manômetro } & Medidor ultrasom & Tempo & Erro \\
\hline$\Delta \mathrm{h} \mathrm{cm} \mathrm{CA}$ & $\mathrm{I} / \mathrm{s}$ & $\mathrm{l} / \mathrm{s}$ & minutos & $\%$ \\
\hline 35,5 & 106,32 & 113,15 & 0 & $6,4 \%$ \\
\hline 35,2 & 105,88 & 113,02 & 18 & $6,7 \%$ \\
\hline 35,2 & 105,88 & 113,05 & 36 & $6,8 \%$ \\
\hline 35,2 & 105,88 & 112,95 & 54 & $6,7 \%$ \\
\hline 35,1 & 105,75 & 112,9 & 72 & $6,8 \%$ \\
\hline
\end{tabular}

Tabela 3: Terminal Ponta da Madeira - VAZANTE (vazão

\begin{tabular}{|c|c|c|c|c|}
\hline \multicolumn{2}{|c|}{ Leitura manômetro } & Medidor ultrasom & Tempo & Erro \\
\hline$\Delta \mathrm{h} \mathrm{cm} \mathrm{CA}$ & $\mathrm{l} / \mathrm{s}$ & $\mathrm{l} / \mathrm{s}$ & minutos & $\%$ \\
\hline 50 & 126,04 & 136 & 0 & $7,9 \%$ \\
\hline 50 & 126,04 & 136 & 18 & $7,9 \%$ \\
\hline 49,8 & 125,79 & 137 & 36 & $8,9 \%$ \\
\hline 49,8 & 125,79 & 137 & 54 & $8,9 \%$ \\
\hline 50 & 126,04 & 136 & 72 & $7,9 \%$ \\
\hline
\end{tabular}

Tabela 4: Terminal Ilha Guaíba - ENCHENTE (vazão fixa):

\begin{tabular}{|c|c|c|c|c|}
\hline \multicolumn{2}{|c|}{ Leitura manômetro } & Medidor ultrasom & Tempo & Erro \\
\hline$\Delta \mathrm{h} \mathrm{cm} \mathrm{CA}$ & $\mathrm{l} / \mathrm{s}$ & $\mathrm{l} / \mathrm{s}$ & minutos & $\%$ \\
\hline 15,5 & 104,49 & 104,5 & 0 & $0,0 \%$ \\
\hline 15,7 & 105,17 & 103,4 & 18 & $-1,7 \%$ \\
\hline 15,5 & 104,49 & 103,4 & 36 & $-1,0 \%$ \\
\hline 15,6 & 104,83 & 104,8 & 54 & $0,0 \%$ \\
\hline 15,6 & 104,83 & 103,5 & 72 & $-1,3 \%$ \\
\hline
\end{tabular}

Tabela 5: Terminal Ilha Guaíba - VAZANTE (vazão fixa):

\begin{tabular}{|c|c|c|c|c|}
\hline \multicolumn{2}{|c|}{ Leitura manômetro } & Medidor ultrasom & Tempo & Erro \\
\hline$\Delta \mathrm{h} \mathrm{cm} \mathrm{CA}$ & $\mathrm{l} / \mathrm{s}$ & $\mathrm{l} / \mathrm{s}$ & minutos & $\%$ \\
\hline 14,5 & 101,006 & 107 & 0 & $5,9 \%$ \\
\hline 14,7 & 101,712 & 106,5 & 18 & $4,7 \%$ \\
\hline 16,5 & 107,866 & 106 & 36 & $-1,7 \%$ \\
\hline 16,5 & 107,866 & 106,2 & 54 & $-1,5 \%$ \\
\hline 16,5 & 107,866 & 106,4 & 72 & $-1,4 \%$ \\
\hline
\end{tabular}


Após a realização dos testes para vazões fixas, foram realizados novos testes visando avaliar possíveis alterações na curva de calibração (aferida em 1987) dos medidores deprimogêneos dos modelos, para a faixa de 40 a 200 l/s.

Com base no manômetro diferencial de pressão do modelo, os testes inciaram-se com uma vazão correspondente a um $\Delta \mathrm{h}=5 \mathrm{~cm}$, aumentando-se o diferencial gradativamente aproximadamente de $5 \mathrm{em} 5 \mathrm{~cm}$. Da mesma maneira feita anteriormente, as vazões indicadas pelos dois equipamentos de medição foram registradas em uma tabela.

Tabela 6: Terminal Ponta da Madeira - ENCHENTE (vazão variável):

\begin{tabular}{|c|c|c|c|}
\hline \multicolumn{2}{|c|}{ Leitura do manômetro } & Medidor ultrasom & Erro \\
\hline$\Delta \mathrm{h} \mathrm{cm} \mathrm{CA}$ & $\mathrm{l} / \mathrm{s}$ & $\mathrm{l} / \mathrm{s}$ & $\%$ \\
\hline 5,5 & 42,1 & 38,1 & $-9,5 \%$ \\
\hline 10,3 & 57,5 & 57,1 & $-0,7 \%$ \\
\hline 15,3 & 69,99 & 70,2 & $0,3 \%$ \\
\hline 20,8 & 81,52 & 79,2 & $-2,8 \%$ \\
\hline 25,3 & 89,86 & 86,2 & $-4,1 \%$ \\
\hline 30,8 & 99,08 & 102,2 & $3,1 \%$ \\
\hline 40,3 & 113,1 & 112,2 & $-0,8 \%$ \\
\hline
\end{tabular}

Tabela 7: Terminal Ponta da Madeira - VAZANTE (vazão variável):

\begin{tabular}{|c|c|c|c|}
\hline \multicolumn{2}{|c|}{ Leitura do manômetro } & Medidor ultrasom & Erro \\
\hline$\Delta \mathrm{h} \mathrm{cm} \mathrm{CA}$ & $\mathrm{l} / \mathrm{s}$ & $\mathrm{l} / \mathrm{s}$ & $\%$ \\
\hline 5,3 & 41,33 & 42,6 & $3,1 \%$ \\
\hline 10,1 & 56,94 & 60,8 & $6,8 \%$ \\
\hline 15,3 & 69,99 & 74,2 & $6,0 \%$ \\
\hline 20,7 & 81,33 & 86 & $5,7 \%$ \\
\hline 24,9 & 89,15 & 93,5 & $4,9 \%$ \\
\hline 30,1 & 97,96 & 104,5 & $6,7 \%$ \\
\hline 40,2 & 113,1 & 120 & $6,1 \%$ \\
\hline
\end{tabular}


Tabela 8: Terminal Ilha Guaíba - ENCHENTE (vazão variável):

\begin{tabular}{|c|c|c|c|}
\hline \multicolumn{2}{|c|}{ Leitura do manômetro } & Medidor ultrasom & Erro \\
\hline$\Delta \mathrm{h} \mathrm{cm} \mathrm{CA}$ & $\mathrm{l} / \mathrm{s}$ & $\mathrm{l} / \mathrm{s}$ & $\%$ \\
\hline 5,3 & 60,54 & 56,8 & $-6,2 \%$ \\
\hline 9,9 & 83,18 & 79,5 & $-4,4 \%$ \\
\hline 15,7 & 105,17 & 101 & $-4,0 \%$ \\
\hline 19,5 & 117,43 & 113,2 & $-3,6 \%$ \\
\hline 24,5 & 131,88 & 130 & $-1,4 \%$ \\
\hline 29,5 & 144,95 & 143 & $-1,3 \%$ \\
\hline 35,7 & 159,72 & 156 & $-2,3 \%$ \\
\hline 39,5 & 168,15 & 170,2 & $1,2 \%$ \\
\hline 45,1 & 179,88 & 180,5 & $0,3 \%$ \\
\hline 49,5 & 188,6 & 190 & $0,7 \%$ \\
\hline
\end{tabular}

Tabela 9: Terminal Ilha Guaíba - VAZANTE (vazão variável):

\begin{tabular}{|c|c|c|c|}
\hline \multicolumn{2}{|c|}{ Leitura do manômetro } & Medidor ultrasom & Erro \\
\hline$\Delta \mathrm{h} \mathrm{cm} \mathrm{CA}$ & $\mathrm{l} / \mathrm{s}$ & $\mathrm{l} / \mathrm{s}$ & $\%$ \\
\hline 5 & 58,772 & 51,8 & $-11,9 \%$ \\
\hline 10,1 & 84,037 & 80,8 & $-3,9 \%$ \\
\hline 15,1 & 103,11 & 100 & $-3,0 \%$ \\
\hline 20 & 118,95 & 118,4 & $-0,5 \%$ \\
\hline 25,2 & 133,79 & 130,3 & $-2,6 \%$ \\
\hline 29,8 & 145,7 & 146,2 & $0,3 \%$ \\
\hline 34,5 & 156,96 & 157,9 & $0,6 \%$ \\
\hline 40 & 169,23 & 176,75 & $4,4 \%$ \\
\hline 45 & 179,67 & 185,45 & $3,2 \%$ \\
\hline 50 & 189,95 & 196,35 & $3,4 \%$ \\
\hline
\end{tabular}

Observa-se, a partir dos resultados apresentados, que as maiores flutuações das vazões ocorreram nos instantes iniciais dos testes, possivelmente em função do pequeno tempo esperado para uma completa estabilização da vazão na tubulação de alimentação. Descartando-se os erros provindos dos instantes iniciais, verificamse desvios da ordem de 5 a $9 \%$ no medidor pertencente ao modelo de Ponta da Madeira e desvios da ordem de 1 à $5 \%$ no medidor pertencente ao modelo de llha Guaíba.

Em função dos resultados dos testes de aferição, providencia-se a atualização das tabelas de aferição dos medidores de vazão, haja visto que um desvio de $5 \%$ na vazão corresponde a um desvio de $10 \%$ na força de arrasto sobre o navio em 
ensaio. Quando a vazão real for mais baixa do que a imposta, o desvio é contra a segurança, ocorrendo o oposto em caso contrário. No entanto seja num caso, quanto no outro, considera-se que são desvios dentro do esperado.

\subsubsection{Restituição dos modelos}

É caracterizada pela saída de água do modelo, após passar pelas estruturas de ensaio. A restituição ideal seria aquela que provocasse o escoamento com as características na seção de saída iguais àquelas encontradas no real. As recomendações para a restituição do modelo são as mesmas citadas no item anterior, ou seja, afastar a seção de saída visando incluir as singularidades presentes no real e provocar uma saída do escoamento o mais uniforme possível, não criando perturbações no escoamento que venham a ser propagadas a montante.

Os sistemas de restituição dos modelos dos Terminais Portuários de Ponta da Madeira, ALUMAR e Ilha Guaíba, assim como os de alimentação, estão presentes nas duas extremidades do modelo, permitindo a representação das correntes de enchente e vazante.

Nestas extremidades, logo após o término da batimetria são colocadas comportas basculantes para o controle dos níveis das marés e, ajustadas a partir da leitura de pontas limnimétricas (com precisão de 0,1mm), como mostrado na Figura 11, colocadas nas mesmas coordenadas cartográficas dos marégrafos situados próximos ao terminal. 


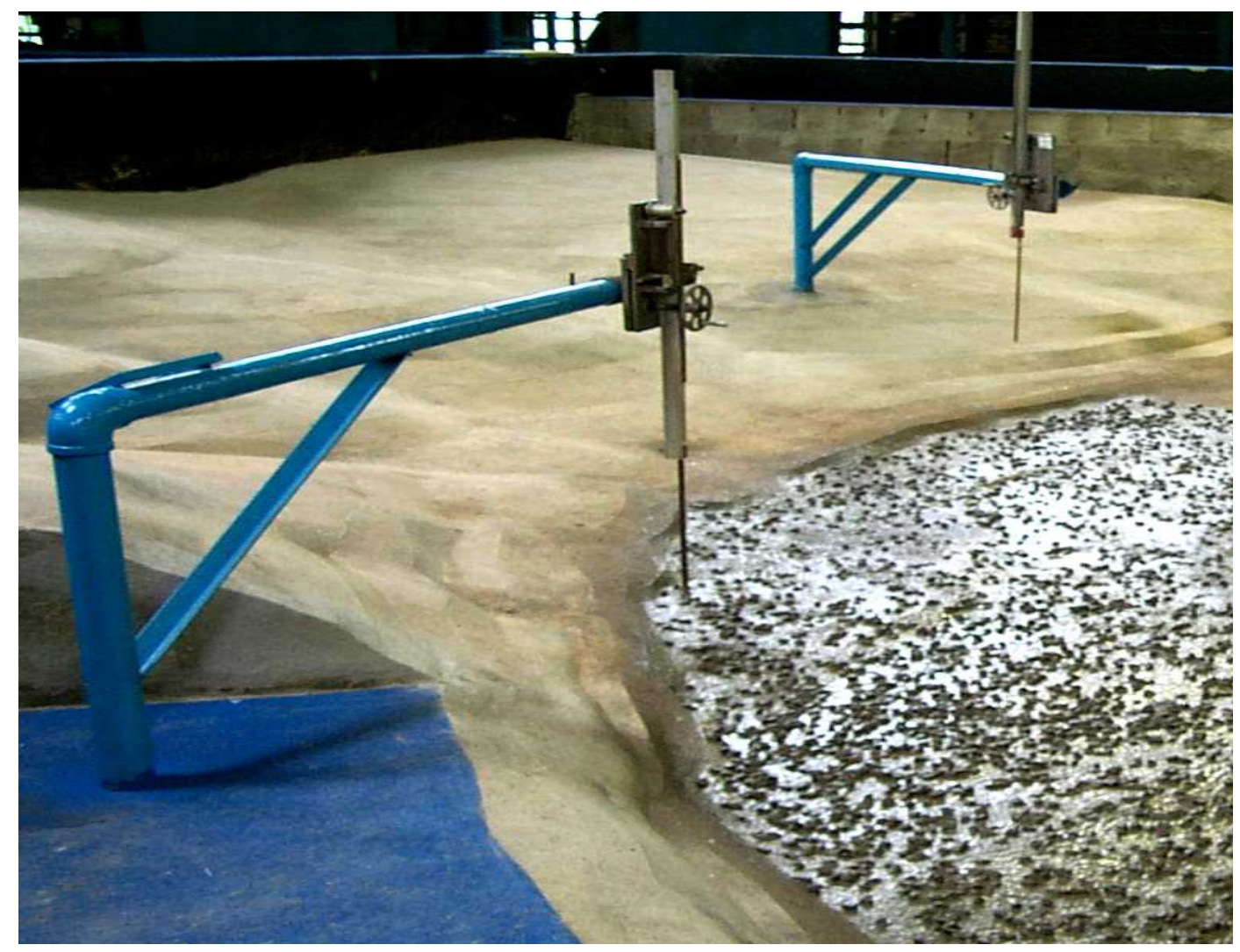

Figura 11: Ponta limnimetrica (fonte: FCTH, 2006)

\subsubsection{Bordas Laterais}

As bordas laterais são aqueles limites do modelo nos quais não ocorre passagem de água. As bordas laterais, que provocarão os efeitos de borda, serão aquelas que não reproduzirão as características do real. Estas bordas são adicionadas quando o limite no real encontra-se a uma distância muito grande, não é conhecido, ou não é único, impossibilitando sua representação.

Sempre que possível, devem ser colocadas afastadas da região em estudo, em pontos de baixa ou nenhuma velocidade, onde se desprezam os efeitos destas bordas laterais, por não provocarem alterações consideráveis na região de estudo.

Nos casos de modelos parciais de obras e em modelos marítimos, as bordas são introduzidas onde existe escoamento e a técnica empregada consiste em definir o 
traçado da borda de acordo com a linha de corrente estimada no real e, desta forma, a ação da borda no escoamento tende a reproduzir a ação da massa líquida não representada. Nos modelos bidimensionais as bordas são localizadas nas seções em que não ocorre passagem considerável de corrente. Em modelos marítimos as bordas seguem as linhas de corrente levantadas em campo e, como estas linhas variam conforme a condição representada devem-se utilizar bordas móveis (placas direcionadoras de correntes), como ilustrado na Figura 12.

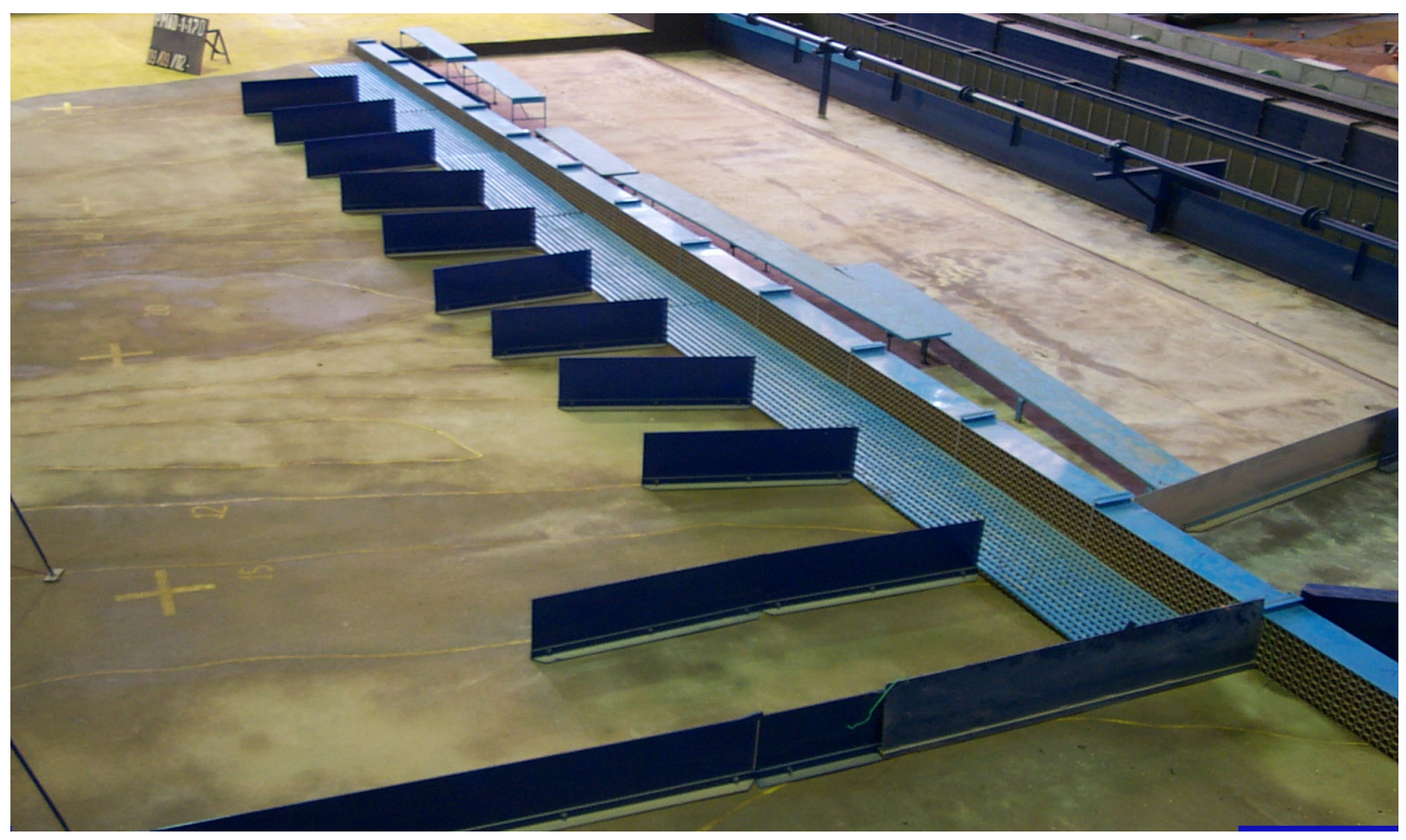

Figura 12: placas direcionadoras de correntes (fonte: FCTH, 2002)

\subsubsection{Calibração hidráulica dos modelos}

Procede-se à calibração hidráulica das velocidades das correntes de maré do modelo físico com a utilização de micromolinetes, acoplados a registradores, posicionados em pontos homólogos aos utilizados nos levantamentos reais. Com os resultados dos ensaios de correntometria executados em campo procede-se ao ajuste da calibração com atuação sobre seis graus de liberdade do modelo: vazão, limites ao largo com placas limitadoras, direcionamento à montante com placas 
direcionadoras, bloqueio do vertedor de alimentação, tamponamento dos tubos das linhas moduladoras e alteração da rugosidade de fundo do modelo.

A profundidade associada a determinada condição de maré é estabelecida com a variação da altura da comporta basculante posicionada na área de restituição do modelo e sua verificação é feita através da leitura de pontas limnimétricas posicionadas em pontos estratégicos, preferencialmente nos pontos de instalação dos marégrafos da região.

Para a validação da calibração hidráulica, são realizados ensaios comparativos aos executados no real com a técnica das trajetórias de derivadores. A partir de câmera posicionada zeniltalmente sobre o modelo são registradas as trajetórias dos derivadores (construídos em escala e lastreados de acordo com as especificações de campo), que em seguida são comparadas e ajustadas às reais para a mesma condição de maré, conforme exemplificado na Figura 13.

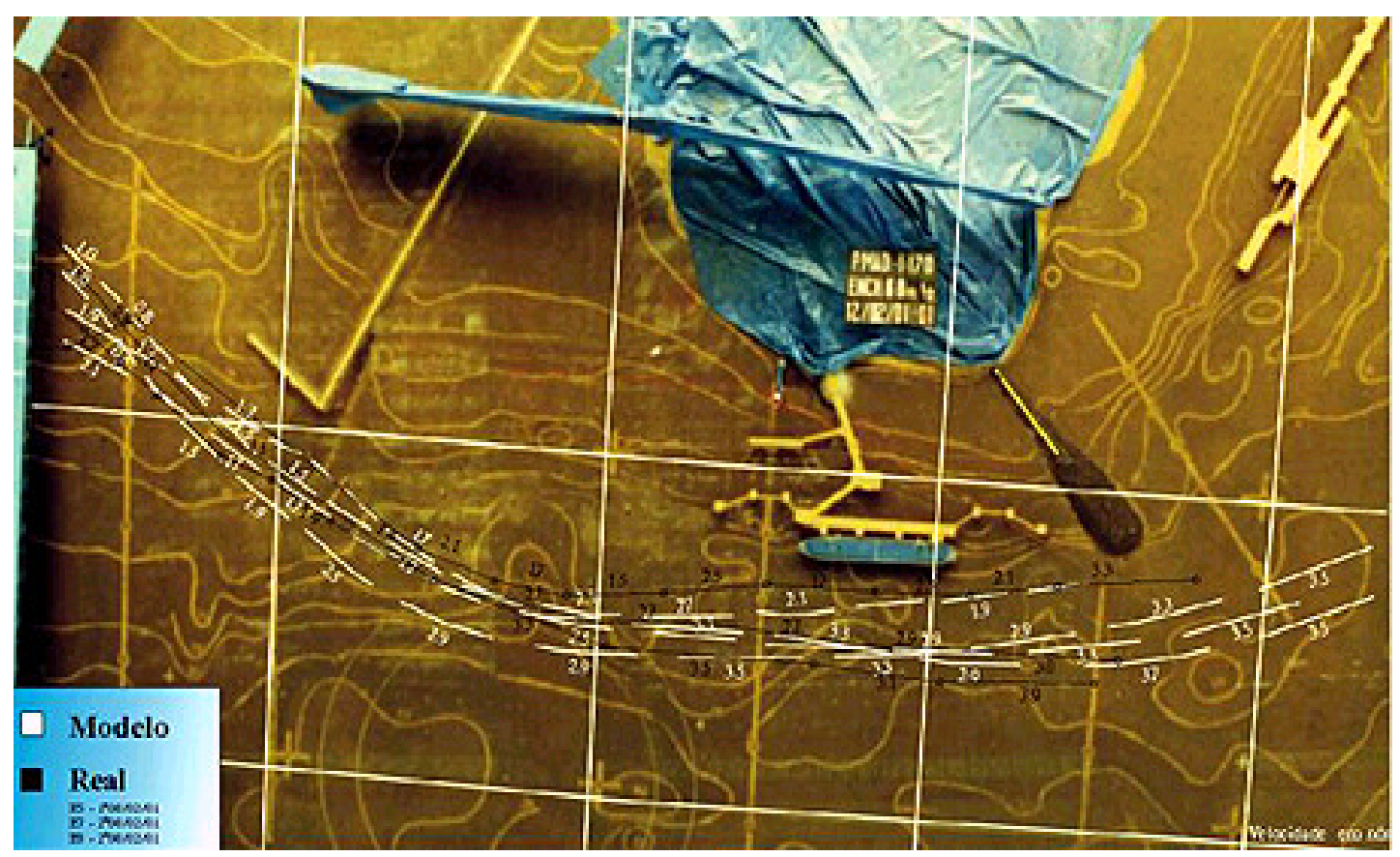

Figura 13: Ensaio de derivadores no modelo físico PDM (fonte: FCTH, 2002) 


\subsection{Criação do SIAMA - Simulador analógico de manobras não tripuladas}

\subsubsection{Revisão Bibliográfica dos métodos de simulação}

As primeiras simulações de manobras de navios feitas em computador eram baseadas em modelos numéricos para os movimentos do navio em águas profundas, águas irrestritas. Estes primeiros modelos eram integrados a rudimentares representações físicas de pontes de comando em tamanho real controladas por computadores. A tecnologia de simulação tem evoluído com o progresso do hardware computacional, com a geração de imagens gráficas (na simulação de imagens para a ponte de comando), e com aumento do conhecimento que os engenheiros navais têm da dinâmica do navio e na criação de modelos numéricos mais precisos (CENTRO DE INSTRUÇÃO ALMIRANTE GARÇA ARANHA).

Além da dinâmica do navio, a modelação de outras condições de operação como: os efeitos das águas rasas (lâminas d'água menores do que 2 vezes o calado); os efeitos das águas restritas, inclusive da sucção dos bancos; a manobrabilidade em baixas velocidades, incluindo as evoluções para atracação; o giro com auxílio de rebocadores e "thrusters"; e as interações entre navios, são muito mais complexas do que a modelagem matemática possa representar. O nível de precisão, fidelidade da trajetória e velocidade do movimento (isto é, resposta do navio) que são necessários à apresentação da replicação do comportamento de manobrabilidade do navio durante o treino pela simulação numérica ou modelo controlado são debatidos dentro do estudo da modelagem hidrodinâmica e da simulação naval (CRENSHAW JR. sd).

A manobrabilidade dos navios é um braço da Arquitetura Naval, originada da necessidade de projetar navios com características de que alcancem requisitos específicos (como o diâmetro do giro, ou diâmetro tático), ou que sejam razoáveis para a utilização do navio. Com o avanço da teoria matemática e da hidrodinâmica do movimento do navio, tornou-se maior a precisão dos modelos numéricos 
computacionais que são desenvolvidos para representar e prever a trajetória dos navios (GONÇALVES, 2005).

A modelagem física de navios dirigida ao treinamento iniciou-se em 1966, com a construção do primeiro centro de treinamento com modelo pilotável do mundo, Port Revel, na França (Figura 14). Este centro surgiu da necessidade de exercitar os comandantes nas manobras e procedimentos de controle dos VLCCs (Very Large Crude Oil Carrier) da ESSO. Naquela época, os VLCCs representavam um avanço espetacular nas dimensões dos navios, com conseqüentes mudanças na manobrabilidade em relação aos navios convencionais. Outros centros de treinamento por modelo pilotável foram criados: na Inglaterra, nos EUA, e os mais recentes na Polônia e na Austrália (VRIES, 1990).

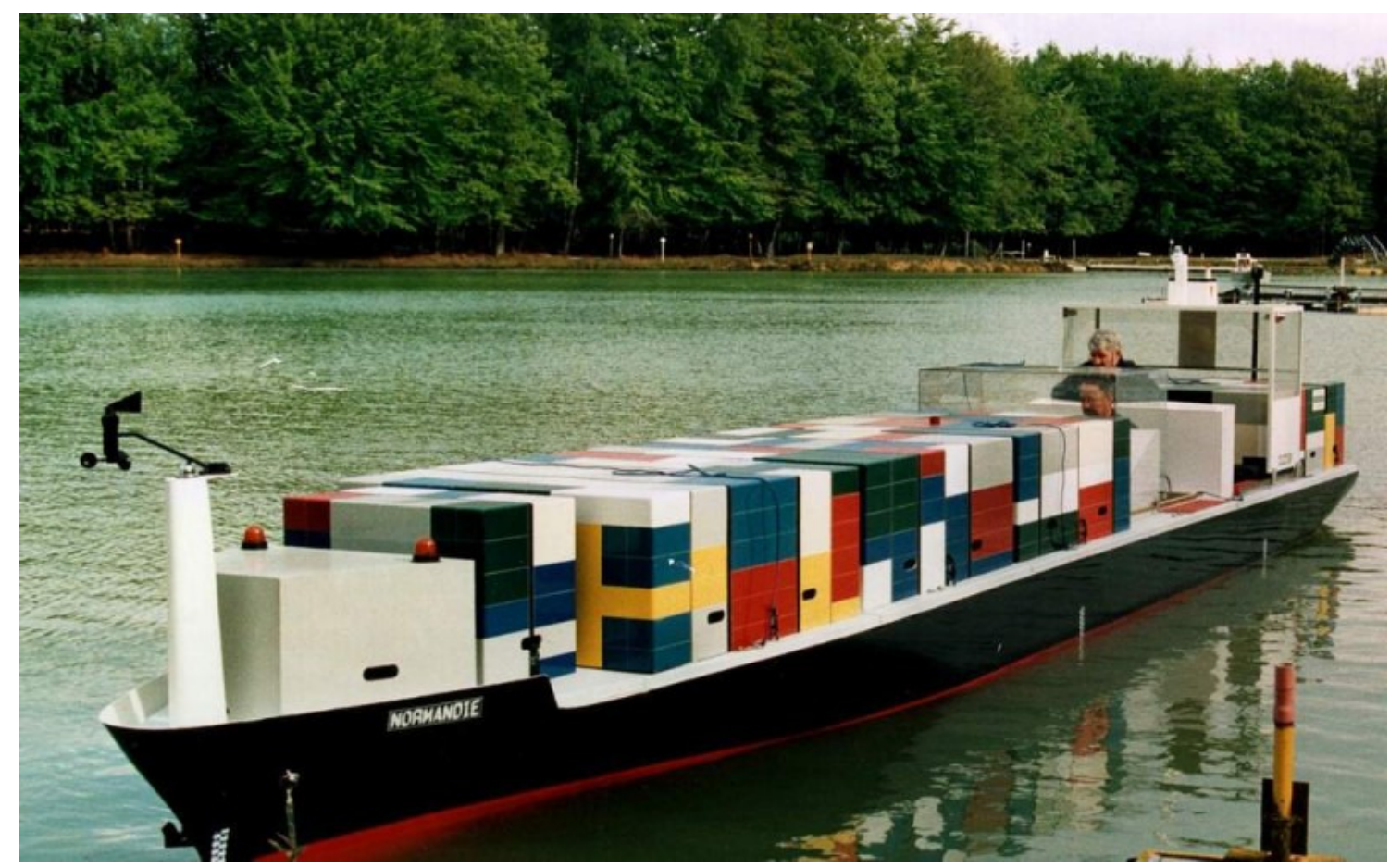

Figura 14: Simulação de manobra em Port Revel (fonte: Port Revel, 2009)

Estes modelos em escala suficientemente grande, com propulsão própria e pilotáveis, podem ser manobrados por uma tripulação a bordo, e simular as manobras de um navio real em lagos apropriados ou águas abrigadas. Tais modelos oferecem a vantagem de uma representação hidrodinâmica relativamente exata com 
cenários realísticos, particularmente para operações em baixas velocidades, atracação, e forças de interação entre navios. As limitações, por estar em escala reduzida, incluem o exagerado efeito do vento, 0 desproporcional efeito estereoscópico da percepção da visão humana, e a significativa compressão da escala de tempo das operações. Em particular, o treinando deve ajustar-se ao tamanho do navio e à aceleração dos eventos durante o treinamento e assimilar conhecimento sobre a manobra, para extrapolar os resultados, conforme sua perícia e habilidades, na situação real.

Os modelos pilotáveis são altamente adequados e eficazes na instrução de marinheiros e Pilotos experientes nos princípios da manobrabilidade de navios e interações hidrodinâmicas. Também têm sido extensivamente utilizados no projeto de canais e no desenvolvimento de estratégias de manobra em situações novas e inusitadas. Além disso, modelos em escala de navios também são empregados em "towing tanks" para estimar vários parâmetros hidrodinâmicos, incluindo o arrasto ("drag force") em águas calmas e a movimentação com as ondas. Os modelos com propulsão própria e rádio-controlados são empregados para avaliar as características de manobrabilidade. Os modelos em escala rádio-controlados também têm sido aproveitados para o exercício de manobras, mas em âmbito muito restrito (PIANC, 1997).

\subsubsection{Classificação dos navios existentes no mundo}

Classificação de navios pela capacidade de carga (em toneladas):

- Handy e Handymax: Tradicionalmente as mulas de carga do mercado marítimo de mercadorias secas, o tipo Handy e o mais recente Handymax continuam populares com suas menos de 50.000 tpb. Esta categoria também é usada para definir pequenos navios tanques para óleo. 
- Panamax: Representam o maior navio capaz de navegar pelo atual Canal do Panamá, o que pode ser aplicado a navios tanque ou de carga; seu comprimento está limitado a 294,1 metros (dependendo do tipo de navio), sua largura a 32,2 metros e seu calado a 12 metros (em água doce). A tonelagem média aproximada para este tamanho de embarcação é de 65.000 tpb, podendo variar entre 50.000 tpb e 80.000 tpb.

- Capesize: Refere-se a um tamanho de navio não bem definido que tem características que o tornam incapaz de cruzar o Canal do Panamá e de Suez, não necessariamente por sua tonelagem, mas por suas dimensões. Estes navios operam em terminais de águas profundas carregando matérias primas, como minério de ferro e carvão. Como conseqüência, os navios da classe "Capesize" navegam via o Cabo Horn (sul da América do Sul) ou o Cabo da Boa Esperança (sul da África). Sua capacidade varia de $80.000 \mathrm{tpb}$ a $175.000 \mathrm{tpb}$.

- Aframax: Navio tanque de capacidade variando entre 75.000 tpb e 115.000 tpb, sendo os maiores navios tanque no sistema de classificação da AFRA (Average Freight Rate Assessment).

- Suezmax: Este padrão, que representa as limitações do Canal de Suez, tem evoluído. Antes de 1967, o Canal de Suez só podia acomodar navios de até 80.000 tpb. O canal foi fechado entre 1967 e 1975 por causa de uma disputa entre países vizinhos. Uma vez reaberto em 1975, a capacidade do canal alcançou os 150.000 tpb. O maior navio capaz de transitá-lo tem seu comprimento limitado a 500 metros, sua largura a 70 metros e seu calado a 21 metros. Está sendo estudado um alargamento do canal para permitir a navegação de navios tanque de 200.000 tpb.

- VLCC / VLOC: Os "Very Large Crude Oil Carrier / Very Large Ore Carrier", tem capacidade entre $150.000 \mathrm{tpb}$ e $320.000 \mathrm{tpb}$. Eles oferecem uma grande flexibilidade de uso dos terminais, já que a maioria pode acomodar suas dimensões, sendo apropriados para portos com limitações de profundidade, principalmente próximo ao 
Mediterrâneo, costa oeste da África e Mar do Norte. Alguns podem cruzar o Canal de Suez em lastro.

- ULCC / ULOC: Os "Ultra Large Crude Oil Carrier / Ultra Large Ore Carrier". tem capacidade entre 300.000 tpb e 550.000 tpb. Usados para carregar óleo cru / minério por longas rotas sem escalas do Golfo Pérsico até a Europa, América e leste da Ásia, via Cabo da Boa Esperança ou Estreito de Mallaca. A grandiosidade destes navios requer a construção de terminais apropriados.

\subsubsection{Desenvolvimento da técnica de simulação em modelo físico}

O SIAMA - Simulador Analógico de manobras não tripuladas do Laboratório de Hidráulica da Escola Politécnica da USP começou a ser concebido em meados de 1991, em função da necessidade de aumentar o conhecimento sobre as manobras realizadas nos Terminais de Ponta da Madeira e Itaqui, ampliando suas opções, mas mantendo a segurança da navegação. Estas manobras são consideradas de difícil execução, devido ao aumento do porte dos navios e das condições adversas das correntes de maré, que em épocas de sigízia podem atingir, em alguns pontos, velocidades de até 5 nós. Por serem manobras não tripuladas e com a reprodução da ação dos rebocadores através do empuxo de fluxo de ar de ventiladores entubados, adotou-se a qualificação de modelo analógico, do ponto de vista da manobra. De fato, diferentemente dos modelos pilotáveis, não há um Piloto a bordo, bem como os rebocadores não atuam fisicamente sobre o navio.

Diferentemente dos simuladores numéricos, fundamentados nos equacionamentos matemáticos, a simulação de manobras de navios em modelos físicos é embasada nas leis da Semelhança Mecânica, permitindo visualizar fisicamente a interação entre escoamento e navio.

O controle da manobra pelo Piloto no laboratório é efetuado a partir de uma sala isolada do modelo, em que se vislumbra um verossímil cenário das instalações 
portuárias por micro-câmara giratória no passadiço do modelo de navio, fornecendo realística visão da manobra.

A capacitação para a simulação de manobras, no Laboratório de Hidráulica da Escola Politécnica da USP teve início em 1991 com:

- pesquisa das referências bibliográficas disponíveis sobre as técnicas de avaliação de manobras de navios;

- obtenção de informações sobre o equipamento e a técnica utilizados na Hydraulics Research Station - Seção de Hidráulica Marítima, em Wallingford, Inglaterra;

- acompanhamento de manobras de atracação e desatracação de grandes mineraleiros no PDM;

- obtenção junto a DOCENAVE de um conjunto de dados básicos para a construção, instrumentação, calibração e operação dos navios e caracterização dos rebocadores;

- construção e instrumentação dos modelos por um especialista em modelos de navios;

- calibração hidrodinâmica dos modelos de navios de acordo com as provas de mar: giros por boreste e bombordo, em lastro e carregado, máximo ângulo do leme, tempo e distância até parar, velocidade em diferentes condições;

- calibração do "bollard-pull" dos rebocadores, reproduzidos pelo empuxo gerado pelo sistema instalado a bordo. 


\section{METODOLOGIA DA CRIAÇÃO DO SIAMA}

\subsection{Montagem do cenário}

O cenário montado para a realização das manobras é composto, basicamente, por três componentes:

- Terminal Portuário (modelo físico hidráulico)

- Navios que operam no terminal (modelos físicos analógicos)

- Sistema de controle remoto

O SIAMA não possui sistema de simulação dos ventos reinantes, desta forma procura-se isolar ao máximo a região no entorno dos modelos com cortinas, para que não haja vento durante a execução das manobras (ver Figura 15).

As cortinas são utilizadas também para se reduzir os reflexos gerados pelas luzes e pelo Sol, além de darem maior destaque ao cenário, evitando dispersão da atenção para eventos que estejam ocorrendo fora do SIAMA.

Completando o cenário, são reproduzidos volumetricamente esquematicamente os Carregadores de Navios e Transportadores de Esteira dos píeres, as bóias de sinalização e os faroletes. É possível também simular manobras noturnas, pois a sinalização luminosa e a iluminação básica dos terminais é reproduzida, inclusive o período em escala de lampejo das bóias e faroletes. 


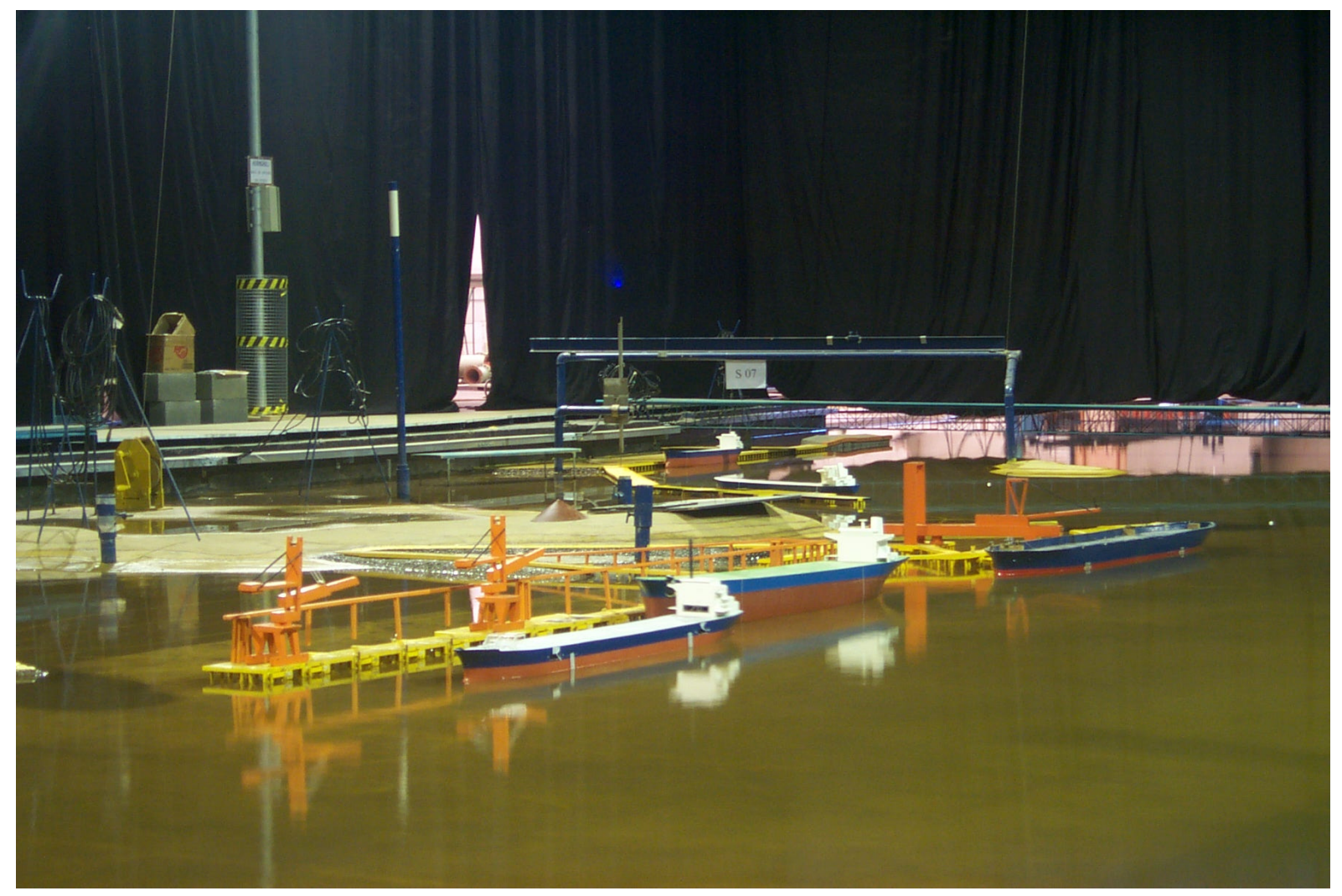

Figura 15: Isolamento do cenário com cortinas pretas (fonte: FCTH, 2006)

\subsection{Modelagem dos navios e superestruturas}

Os navios modelados para os ensaios no simulador são construídos de acordo com projetos estruturais (plano de linhas e cavernas) dos navios reais, que são materializadas em compensado naval (ver Figura 16 e Figura 17), com mesma redução de escala do modelo físico, que é de 1:170.

Os modelos de navios são produzidos a partir de um molde confeccionado em fibra de vidro, que permite a laminação de várias cópias do navio.

Os modelos possuem base interna em compensado naval, além de convés e castelo de popa (Figura 18).

Existem seis modelos de navios instrumentados para a reprodução de manobras conduzidas via rádio-controle (ver Tabela 10). São os modelos dos mineraleiros: 
ULOC (575.000 tpb), CHINAMAX (400.000 tpb), Berge Stahl (365.000 tpb), NM Docecanyon classe VLOC-VLCC (ORE-OIL de 270.000 tpb), classe CAPESIZE (150.000 tpb), classe PANAMAX (75.000 tpb).

Tabela 10: Dimensões características dos navios instrumentados para manobras

\begin{tabular}{|c|c|c|c|c|c|c|}
\hline Nome do navio & Classe & Dimensões: & Comprimento & Boca & Calado & Porte Bruto \\
\hline \multirow{2}{*}{ DOCEALFA } & \multirow{2}{*}{ Panamax } & Modelo $(\mathbf{c m})$ & 142,3 & 19,0 & $\overline{8,0}$ & $15,4 \mathrm{~kg}$ \\
\hline & & Real (m) & 241,9 & 32,3 & 13,6 & $75,6 \mathrm{kt}$ \\
\hline \multirow{2}{*}{ DOCEBAY } & \multirow{2}{*}{ Capesize } & Modelo $(\mathbf{c m})$ & 162,9 & 25,6 & $\overline{10,4}$ & $31 \mathrm{~kg}$ \\
\hline & & Real (m) & 277,0 & 43,5 & 17,6 & $152,3 \mathrm{kt}$ \\
\hline & & & & & & \\
\hline \multirow{2}{*}{ DOCECANYON } & \multirow{2}{*}{ VLCC/VLOC } & Modelo (cm) & 199,3 & 32,4 & 12,6 & $56,2 \mathrm{~kg}$ \\
\hline & & Real (m) & 338,8 & 55,1 & 21,4 & $276,1 \mathrm{kt}$ \\
\hline \multirow{2}{*}{ BERGE STAHL } & \multirow{2}{*}{ ULOC } & Modelo $(\mathbf{c m})$ & 211,8 & 38,2 & 13,5 & $74,3 \mathrm{~kg}$ \\
\hline & & Real (m) & 360,1 & 64,9 & 23,0 & $365 \mathrm{kt}$ \\
\hline & & & & & & \\
\hline \multirow{2}{*}{ CHINAMAX } & \multirow{2}{*}{ ULOC } & Modelo (cm) & 214,7 & 38,8 & 13,5 & $100 \mathrm{~kg}$ \\
\hline & & Real (m) & 365,0 & 66,0 & 23,0 & $400 \mathrm{kt}$ \\
\hline & & & & & & \\
\hline \multirow{2}{*}{ SEM NOME } & \multirow{2}{*}{ ULOC } & Modelo (cm) & 250 & 47,1 & 14,7 & $125,2 \mathrm{~kg}$ \\
\hline & & Real (m) & 425 & 80 & 25 & $615 \mathrm{kt}$ \\
\hline
\end{tabular}




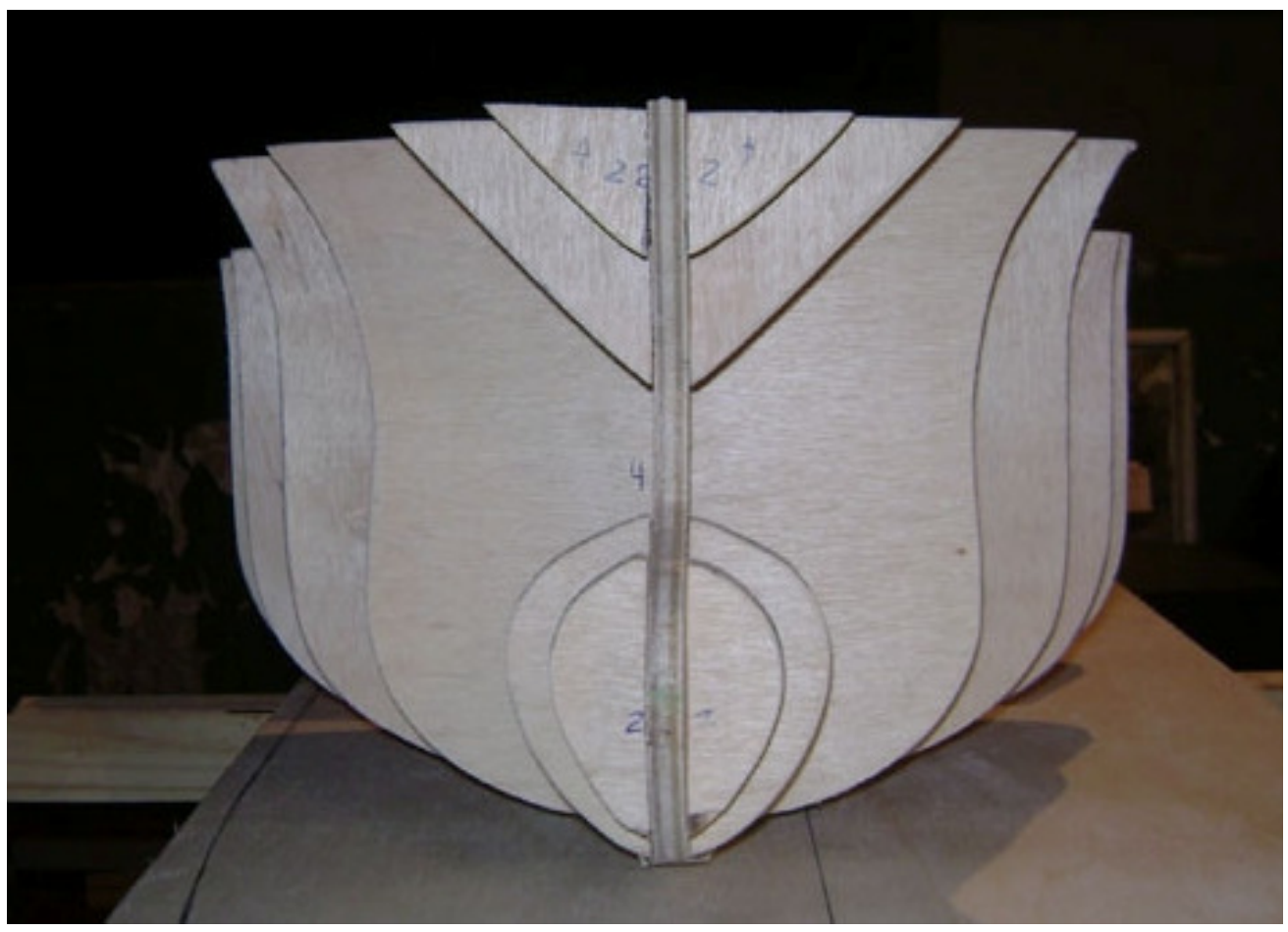

Figura 16: Detalhe das cavernas do modelo de navio Chinamax (fonte: FCTH, 2009)

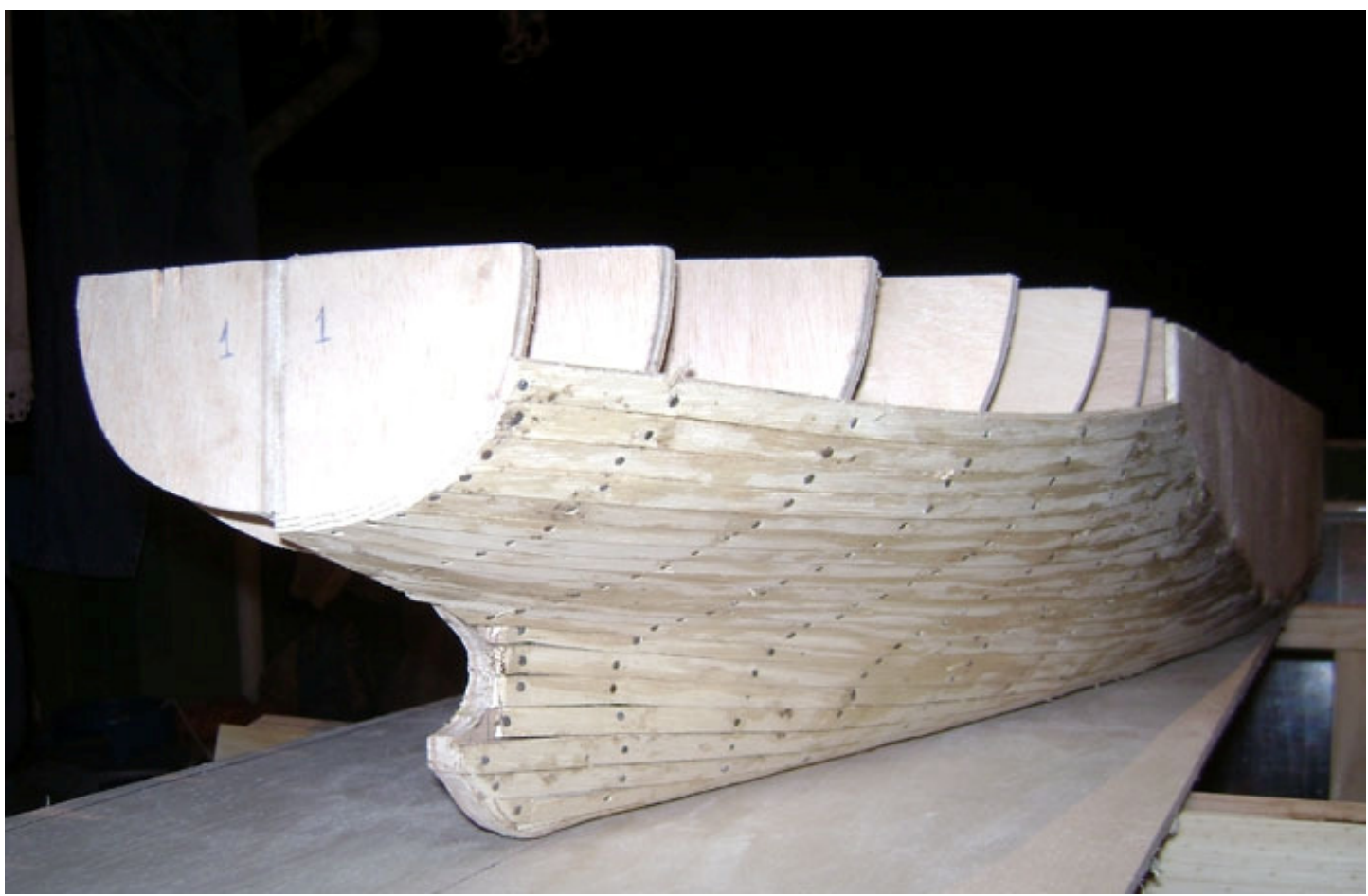

Figura 17: Detalhe das linhas do modelo de navio Chinamax (fonte: FCTH, 2009) 


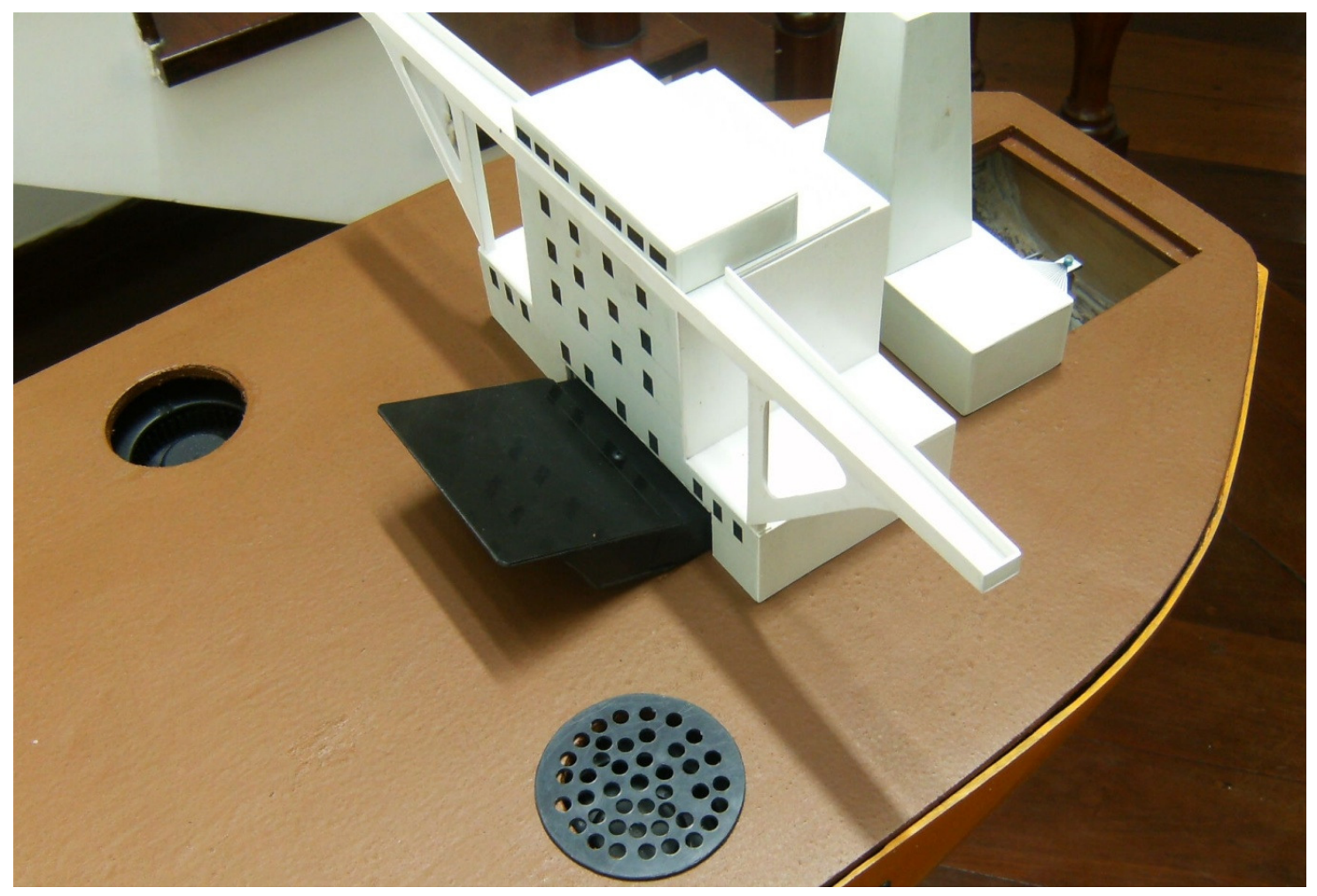

Figura 18: Detalhe do castelo de popa do modelo de navio Chinamax (fonte: FCTH, 2009)

Todos os modelos de embarcações possibilitam a simulação para quaisquer condições de calado do navio, em lastro ou todo carregado. Existem locais, na parte interna do navio, apropriados para a colocação de pesos-lastros, de forma a variar o calado. Nas condições de simulação de hidrodinâmica somente de correntes (esforços puramente horizontais), basta a colocação dos pesos em qualquer posição interna ao casco, de modo a garantir a condição "even-keel", ou com trim operacional. Nos casos em que a hidrodinâmica envolve agitação, torna-se necessário calibrar os períodos naturais do navio de arfagem ("heave"), balanço ("roll") e caturro ("pitch"), que são, respectivamente, as translações verticais e as rotações em torno do eixo longitudinal e transversal. Neste último caso, os pesos a bordo devem ser distribuídos convenientemente para gerar os momentos internos de acordo com o projeto do navio. 


\subsection{Simulação e calibração dos rebocadores portuários}

Os rebocadores portuários auxiliam os navios durante as manobras de atracação ou desatracação (ver Figura 19), empurrando ou puxando, conforme comandos solicitados via rádio pelos Práticos, responsáveis pela execução da manobra.

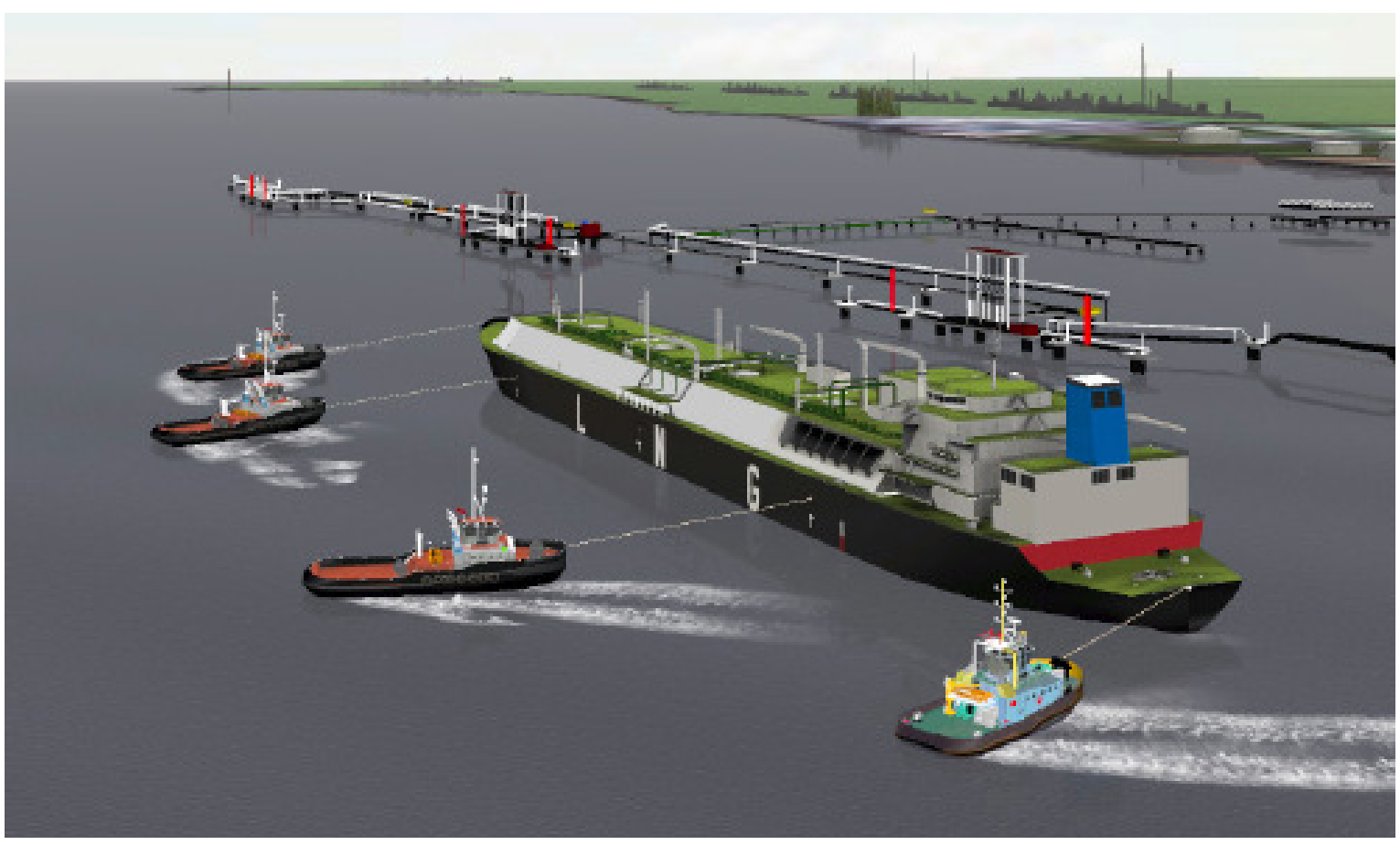

Figura 19: Ilustração de rebocadores auxiliando manobra (fonte: MARIN, 2008)

Os modelos de navios do SIAMA permitem a simulação de até seis rebocadores simultaneamente, com potências (bollard-pull) de 50 ou $75 \mathrm{tf}$.

Os rebocadores portuários são simulados através de ventiladores entubados, embutidos no interior do casco, abaixo do convés principal, com o ponto de aplicação do empuxo próximo da linha d'água, como na realidade. Para a disposição dos ventiladores entubados sob o convés foi colocada uma transição do perfil circular para um perfil retangular em suas extremidades. Este conjunto tem o comprimento exato para que cada extremidade de perfil retangular fique faceada ao casco. Para isto, foi aberta uma janela retangular no casco (ver Figura 20). 
O efeito combinado de qualquer número de rebocadores pode ser sempre decomposto em três forças: uma que pode ser considerada agindo longitudinalmente, e é representada pelo efeito segundo o eixo longitudinal do modelo, de modo a ser capaz de exercer uma força ao longo do eixo do navio em ambos os sentidos; as outras duas forças podem ser consideradas agindo transversalmente ao eixo do navio, uma à vante e outra à ré, sendo representadas por ventiladores entubados nestas duas posições, podendo exercer forças em ambos os sentidos.

A alimentação dos ventiladores entubados de $12 \mathrm{Vcc}$ é feita através de fios de bitola apropriada. Em cada circuito dos ventiladores entubados foi colocado um regulador de 10Vcc, porque durante o funcionamento do barco há a descarga da bateria e a aferição do conjunto varia com a tensão de alimentação. Deste modo evita-se que a aferição sofra alterações durante os ensaios

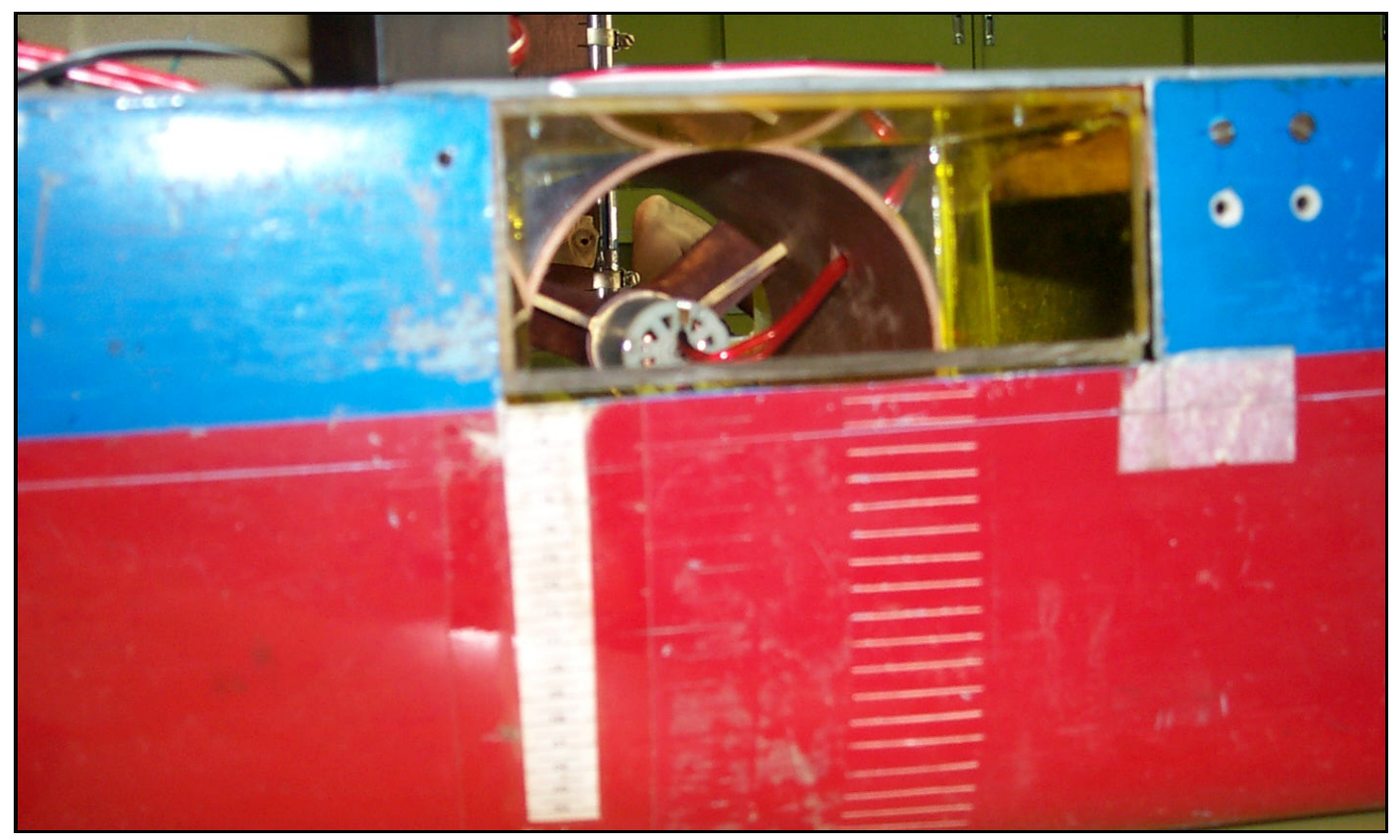

Figura 20: Detalhe de ventilador entubado, embutido no casco do navio (fonte: FCTH, 2002)

A calibração dos ventiladores entubados é realizada com base nas escalas de força de cada tipo de rebocador (50 e 75tf). 
Considerando o fato dos rebocadores não estarem fisicamente representados, mas tendo o seu efeito reproduzido por empuxos dos ventiladores entubados, tornou-se necessário reduzir a eficiência de empuxo dos mesmos com relação à prova estática, uma vez que parte do desempenho é perdido no posicionamento contra as correntes de maré. Assim, seguindo-se sugestão da Praticagem, procedeu-se a uma redução de 25 \% no Bollard Pull da prova de mar para todas as calibrações dos ventiladores entubados.

\subsection{Calibração do sistema de propulsão e leme dos navios}

Embarcados nos modelos de navios do SIAMA existem: motor propulsor para o hélice, servo-mecanismo para acionamento do leme e circuitos para controle das velocidades ("speeds").

A calibração do navio é realizada de acordo com a prova de mar fornecida pelo armador: giros por boreste e bombordo em lastro e carregado com máximo ângulo do leme (Figura 21 e Figura 22), tempo e distância até parar, velocidade em diferentes condições de máquina e carregamento (GEOTRON, 1982). 


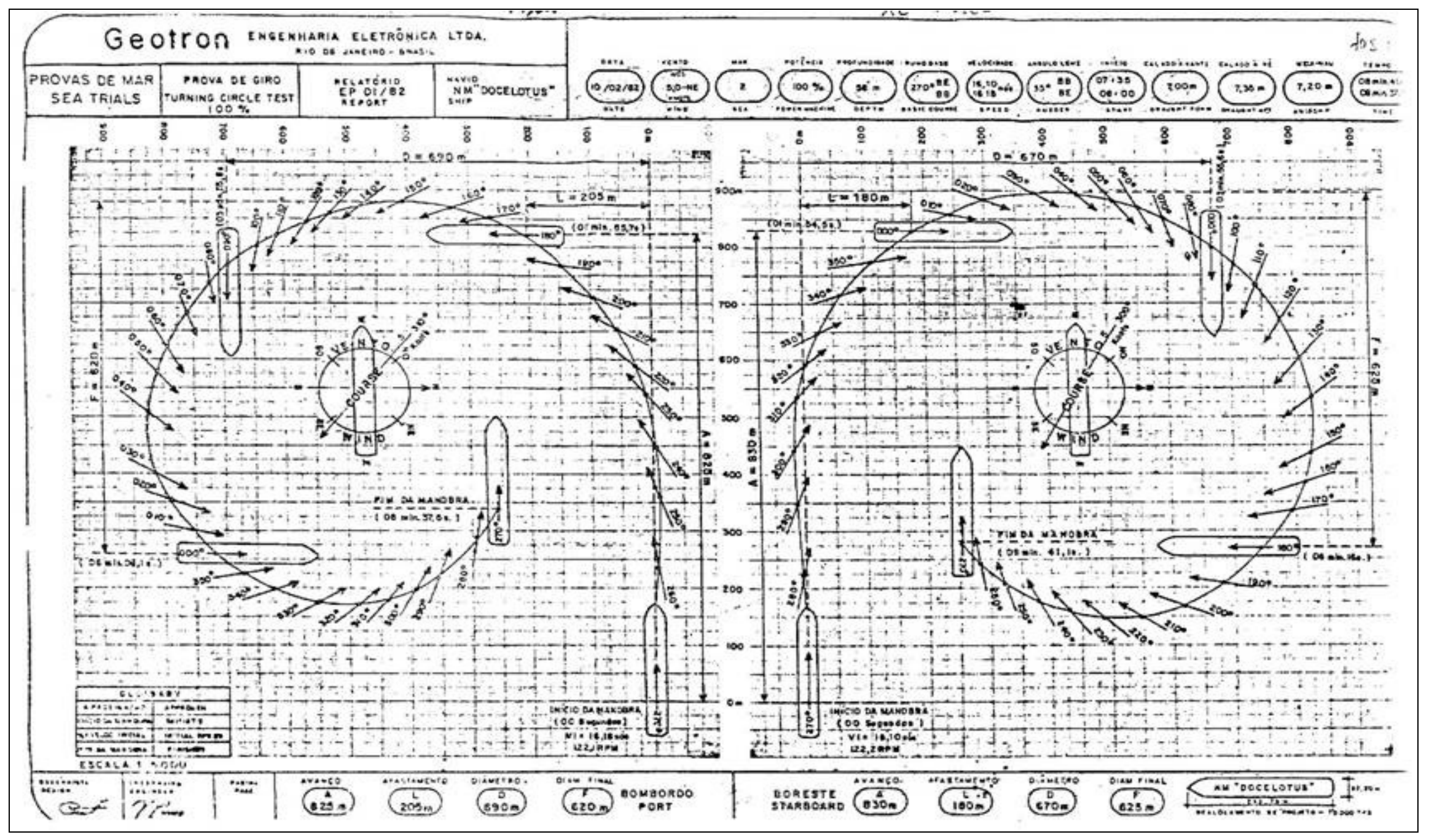

Figura 21: Relatório de prova de giro realizada com Panamax (fonte: Geotron, 1982) 


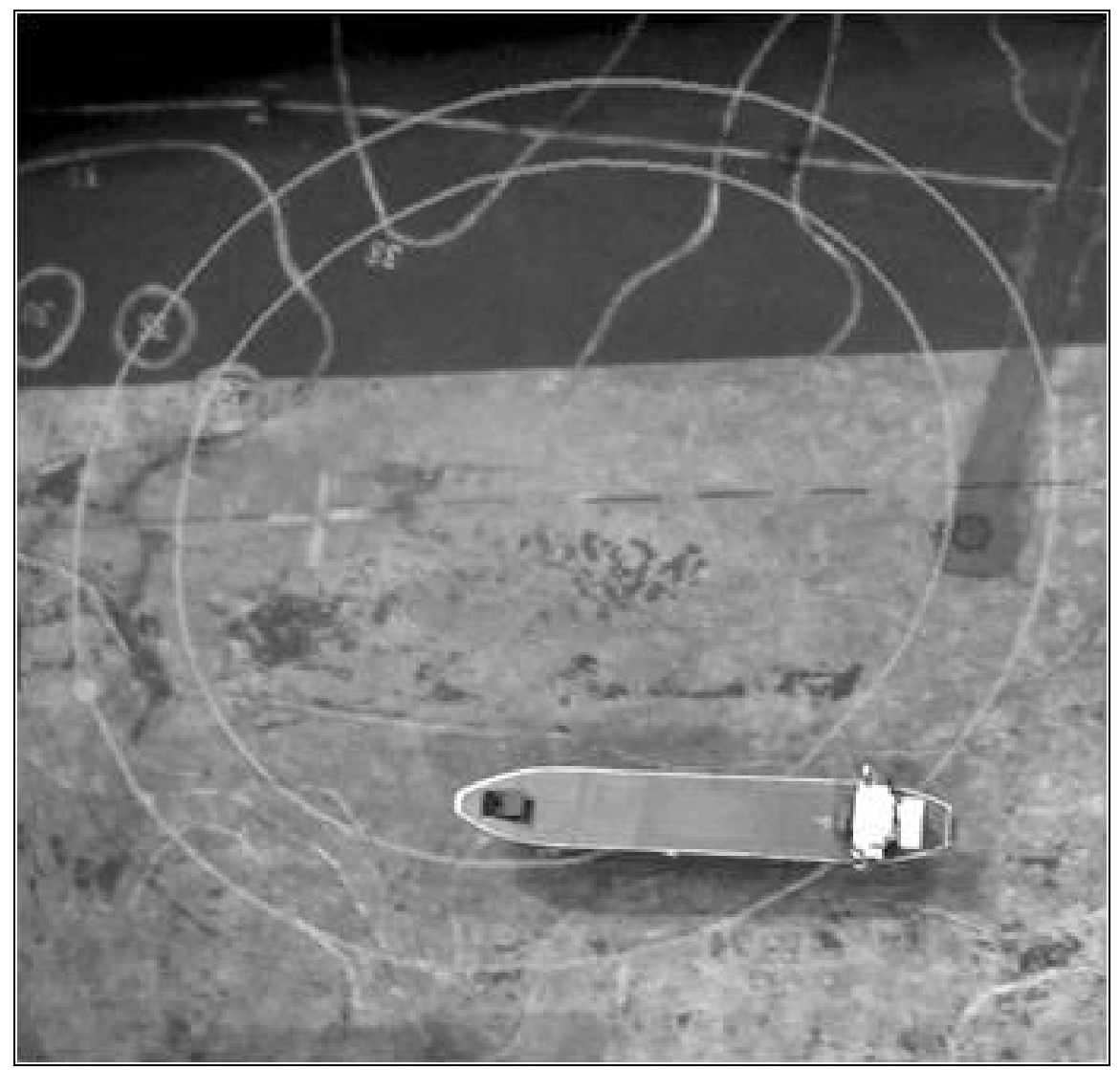

Figura 22: Calibração do modelo de navio Panamax no SIAMA (fonte: FCTH, 1991)

\subsection{Sistema de rádio-controle}

O console de comando do controle remoto via rádio (Figura 23) consiste num painel com escalas desenhadas sobre o mesmo para os canais: posição do leme, rotação do hélice acoplado à máquina do navio, rotação dos hélices de ventiladores entubados embutidos para reproduzir a ação dos rebocadores que manobram o navio. O ajuste dos comandos é feito por um braço fixado ao eixo de um potenciômetro, como um ponteiro de relógio fixo ao eixo do relógio. Isto faz com que as marcações das escalas estejam bem distribuídas, permitindo comando individualizado preciso (Figura 24). 


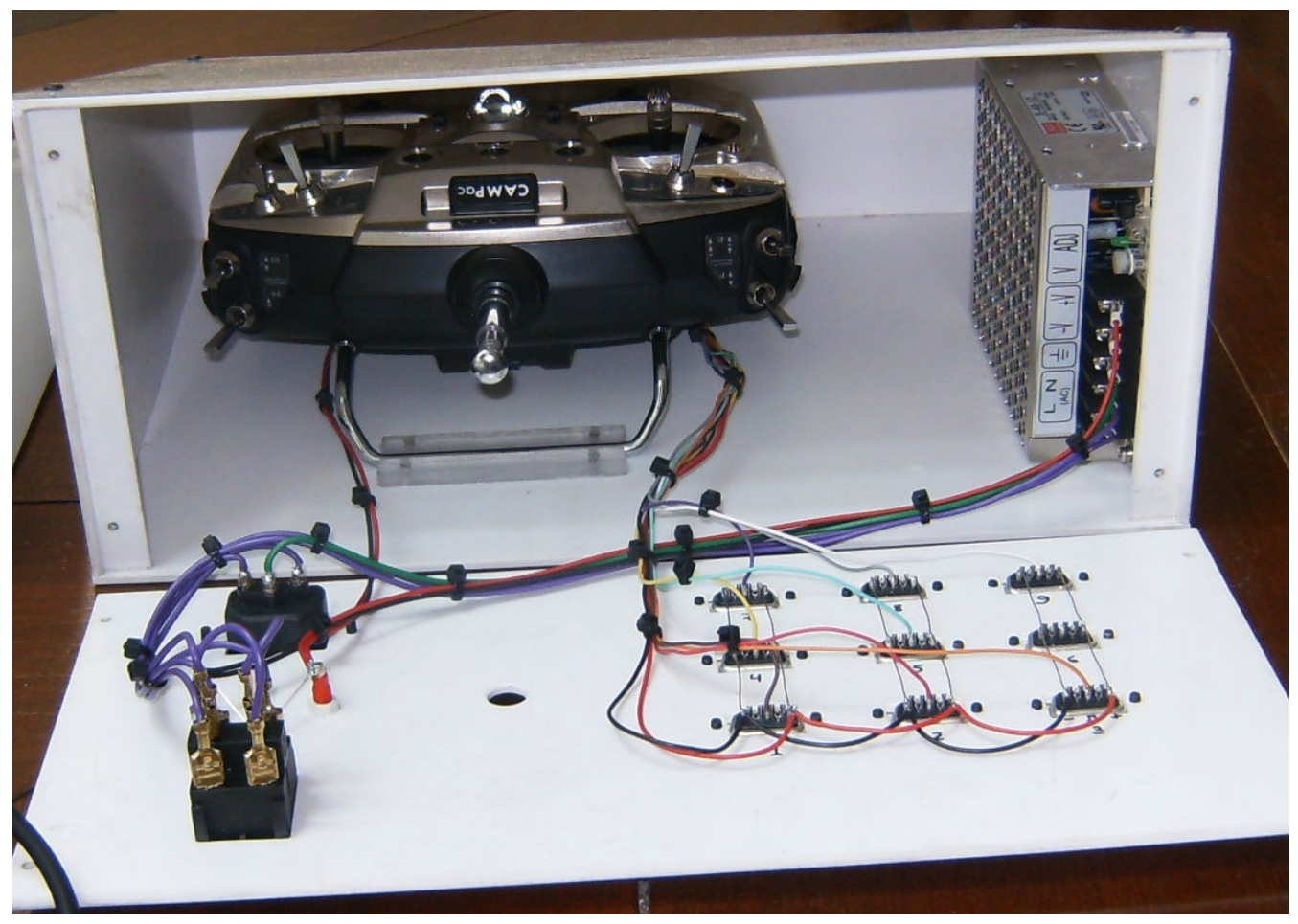

Figura 23: Vista do interior do controle (fonte: FCTH, 2008)

O sinal de rádio-controle captado no modelo atua nos servos-mecanismos, instalados no navio, onde também se encontram duas baterias.

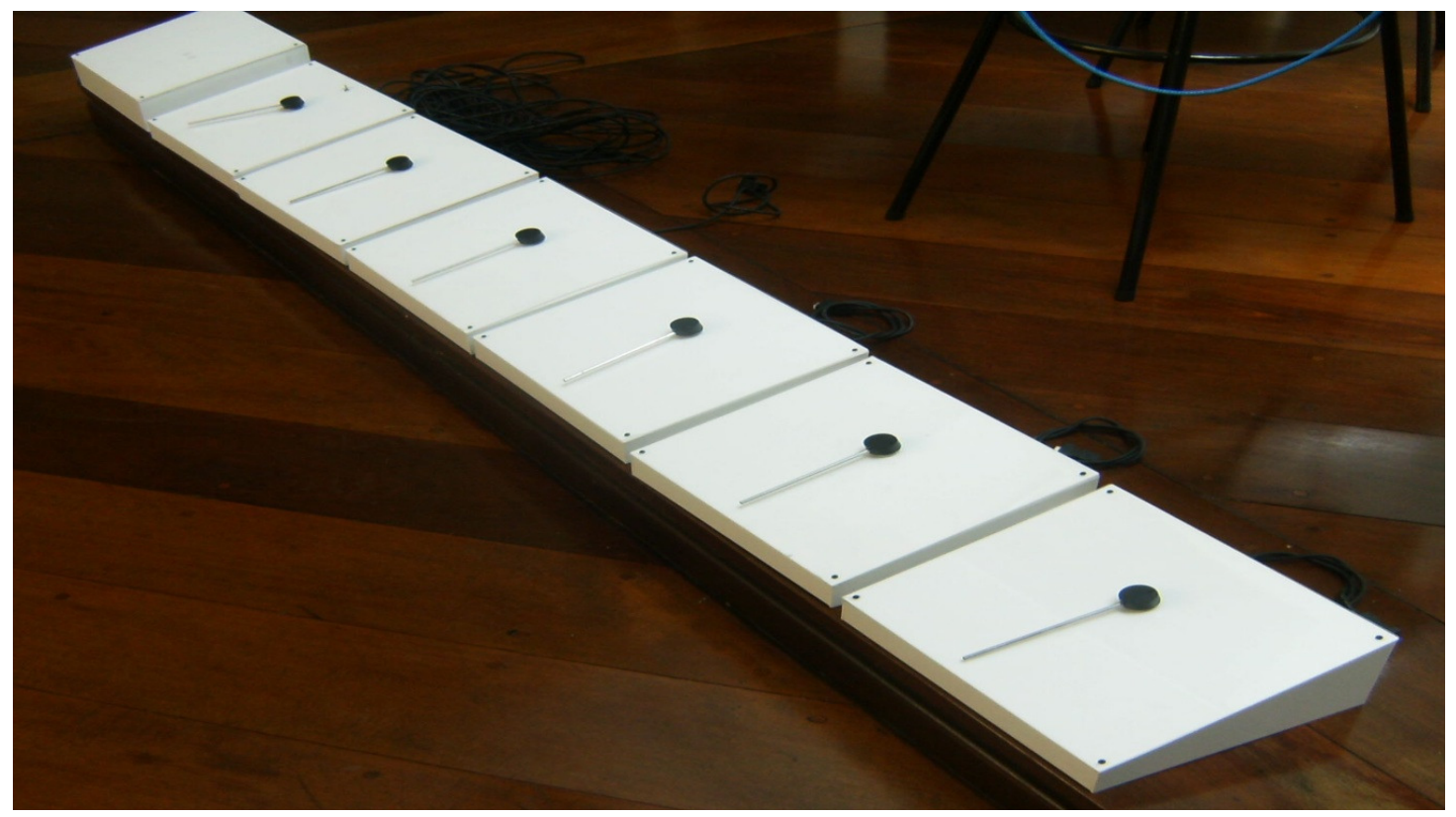

Figura 24: Consoles de comandos do navio e rebocadores (fonte: FCTH, 2008) 


\subsection{Visualização da manobra para controle a distância}

O controle da manobra realizada pelo Piloto no laboratório é efetuado via rádio a partir de uma sala isolada do modelo, em que se visualiza um completo cenário das instalações portuárias por projeção num telão da imagem de 2 micro-câmaras giratórias (selecionadas mutuamente exclusivas) no passadiço do modelo de navio (asa de boreste e de bombordo). Estas micro-câmaras reproduzem o campo da visão humana, fornecendo realística visão da manobra pelo Prático (Figura 25), bem aproximada àquela que se observaria nestas mesmas posições durante as manobras, bem como com um relógio que apresenta o tempo real da manobra.

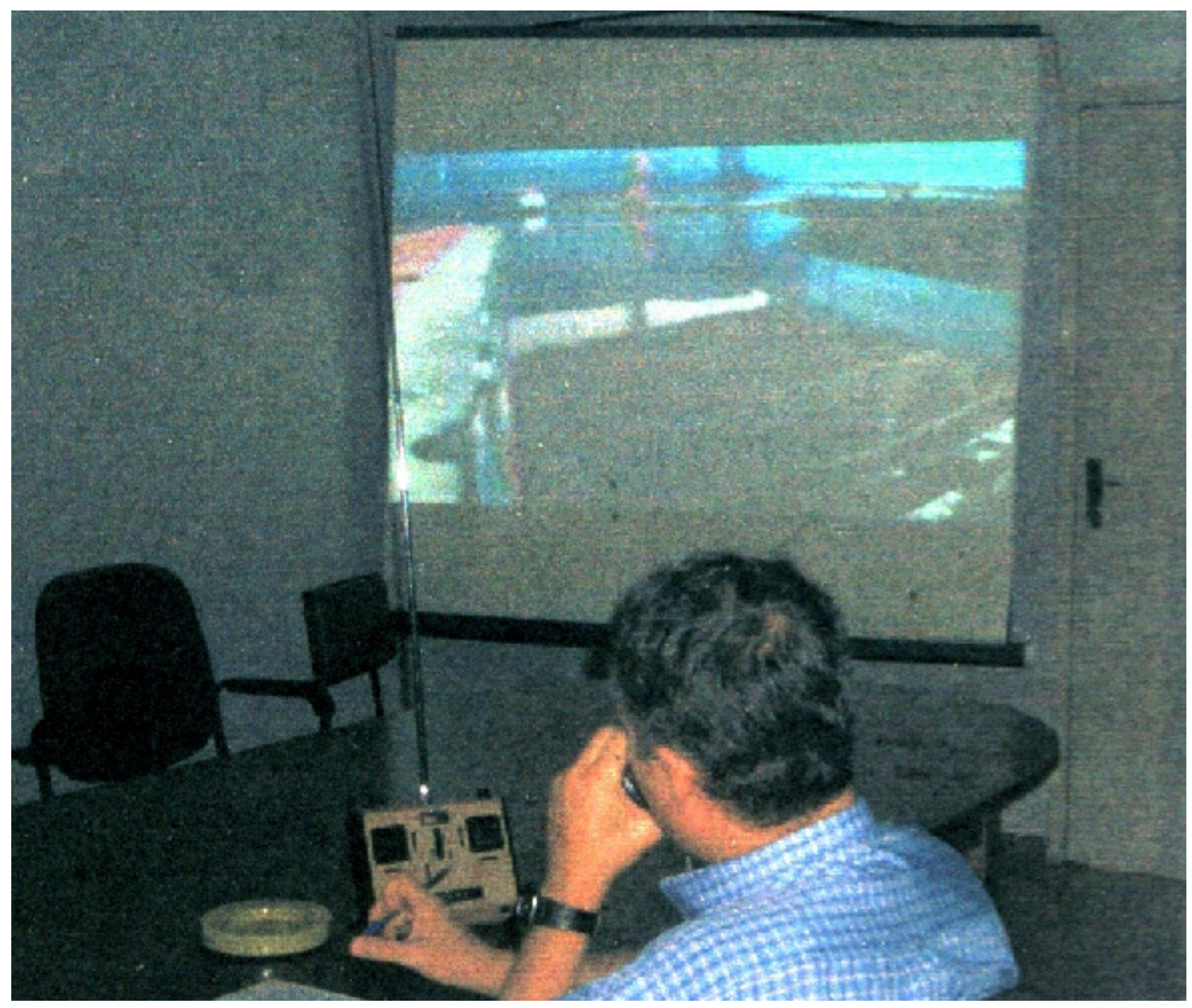

Figura 25: Visualização de manobra de atracação no TMPM (fonte: FCTH, 2000) 
As lentes utilizadas nas micro-câmaras têm um campo visual que é próximo ao da visão humana. As câmaras giram no plano horizontal de modo a permitir ao Piloto ter a visão da proa até a popa. Assim, pode-se ter uma imagem de $180^{\circ}$ de abertura aproximadamente. O acionamento da câmara é feito por um segundo controle remoto, que é comandado manualmente pelo Piloto. A câmara associada a um pivô giratório foi fixada a um servo-mecanismo e este ao convés.

\subsection{Avaliação das manobras}

Dispondo-se do modelo de navio instrumentado e calibrado foram efetuados ensaios de manobras, na presença dos Práticos e de representantes das empresas operadoras dos terminais, incluindo a sua consultoria de navegação. Por ocasião dos ensaios são discutidos, além da melhor estratégia de manobra perante diferentes condições de maré e ondas, os diferenciados aspectos que implicam na segurança da navegação, sob as considerações de procurar atingir-se a produtividade com segurança.

As manobras efetuadas pelos Práticos são objetivamente avaliadas por meio das respostas e comentários preenchendo um questionário. Os Práticos recebem antes do início dos ensaios uma explanação sobre a resposta do SIAMA na reprodução da hidrodinâmica e quanto à metodologia de condução do navio. Após esta apresentação, podem se familiarizar com a técnica modelística, avaliar a hidrodinâmica com auxílio de confetes, dar sugestões sobre a colocação de auxílios à navegação e efetuar manobras com visão direta (a "vôo de pássaro") e por meio da câmara giratória no passadiço do navio.

A avaliação deve ser preferencialmente realizada por três especialistas. O Prático que executou a manobra, o consultor de navegação e outro Prático independente, que esteja acompanhando a manobra (GONZALEZ, 1990).

A avaliação é feita em formulário de questionário específico (Tabela 11), com pontuação e ponderação de quesitos, definidos pelas entidades envolvidas, sobre 
cada manobra, de modo a estabelecer objetivamente o grau de segurança e operacionalidade, contemplando: atitude do navio, número de partidas da máquina, intervalo temporal entre as ordens do Piloto, tempo total, dificuldades de giro, atuação da hidrodinâmica sobre o navio, riscos de acidentes (encalhe e/ou choques com estruturas e/ou outros navios atracados), rotações da máquina e espaço disponível

Tabela 11: Questionário de avaliação das manobras - exemplo de preenchimento de um ensaio

\begin{tabular}{|c|c|c|c|c|c|c|c|}
\hline Data: & $23 / 03 / 01$ & * Pier I: & 270 & Atracação:x & Desat. & $\begin{array}{l}\text { Rebocadores } \\
\text { por: }\end{array}$ & $\mathrm{BB}$ \\
\hline $\begin{array}{l}\text { Ensaio } \\
\text { n.o: }\end{array}$ & 4 & $\begin{array}{l}\text { * Pier III } \\
\text { (Sul): }\end{array}$ & 150 & Carga & calado (m) & Prático: & Quirino \\
\hline Maré: & $6,0 \mathrm{~m} \mathrm{3/4}$ & $\begin{array}{l}\text { * Pier III } \\
\text { (Norte): }\end{array}$ & 75 & $\begin{array}{l}- \\
\text { plena }\end{array}$ & & & \\
\hline \multicolumn{2}{|c|}{$\begin{array}{l}\text { * Navios Atracados } \\
\text { (1000 DWT) }\end{array}$} & Manobra: & B25 & lastro & parcial $x$ & & \\
\hline
\end{tabular}

\begin{tabular}{|c|c|c|c|c|c|c|c|c|c|c|c|c|c|}
\hline \multirow[b]{2}{*}{$\begin{array}{l}\text { Conceitos: } 0 \text { inviável / } 5 \text { aceitável / } 10 \\
\text { adequado }\end{array}$} & \multicolumn{3}{|c|}{$\begin{array}{r}\text { Comandante: } \\
\text { Quirino }\end{array}$} & \multicolumn{3}{|c|}{$\begin{array}{c}\text { Prático Observador: } \\
\text { Antônio }\end{array}$} & \multicolumn{2}{|c|}{$\begin{array}{r}\text { Consultoria: } \\
\text { Gonzalez }\end{array}$} & \multicolumn{3}{|c|}{$\begin{array}{l}\text { Capitão do } \\
\text { Porto: } \\
\text { Uchoa }\end{array}$} & \multirow[t]{2}{*}{ Média } & \multirow{2}{*}{$\begin{array}{c}\text { Pesos } \\
\% \\
\end{array}$} \\
\hline & 0 & 5 & 10 & $\overline{0}$ & 5 & 10 & $\overline{0}$ & 10 & 0 & 5 & 10 & & \\
\hline \multicolumn{14}{|l|}{$\begin{array}{l}\text { 1. Atuação dos } \\
\text { rebocadores }\end{array}$} \\
\hline $\begin{array}{l}\text { Número de } \\
\text { comandos }\end{array}$ & & & 10 & & & & & & & & 10 & 10 & 3,3 \\
\hline Forças & & & 10 & & & & & & & & 10 & 10 & 3,3 \\
\hline Atitude & & & 10 & & & & & & & & 10 & 10 & 3,3 \\
\hline \multicolumn{14}{|l|}{$\begin{array}{l}. \\
\text { Máquina } \\
\end{array}$} \\
\hline Atuação & & 5 & & & & & & & & & 10 & 7,5 & 5 \\
\hline \multicolumn{14}{|l|}{$\begin{array}{l}\text { 3. Análise do alinhamento do navio e } \\
\text { manutenção da posição }\end{array}$} \\
\hline $\begin{array}{l}\text { Capacidade de manter o } \\
\text { navio na trajetória desejada }\end{array}$ & & 5 & & & & & & & & & 10 & 7,5 & 3,3 \\
\hline $\begin{array}{l}\text { Capacidade de avaliação da } \\
\text { posição do navio }\end{array}$ & & 5 & & & & & & & & & 10 & 7,5 & 3,3 \\
\hline Atitude & & 5 & & & & & & & & & 10 & 7,5 & 3,3 \\
\hline \multicolumn{14}{|l|}{$\begin{array}{l}\text { 4. Espaçamento com o } \\
\text { navio atracado mais } \\
\text { próximo }\end{array}$} \\
\hline Folga & & & 10 & & & & & & & & 10 & 10 & 15 \\
\hline \multicolumn{14}{|l|}{$\begin{array}{l}\text { 5. Controle e } \\
\text { Segurança }\end{array}$} \\
\hline $\begin{array}{l}\text { Houve condição de controle no } \\
\text { decorrer de toda a manobra }\end{array}$ & & & 10 & & & & & & & & 10 & 10 & 5 \\
\hline $\begin{array}{l}\text { Houve condição de segurança no } \\
\text { decorrer de toda a manobra }\end{array}$ & & & 10 & & & & & & & & 10 & 10 & 5 \\
\hline $\begin{array}{l}\text { 6. Avaliação global da } \\
\text { manobra }\end{array}$ & & & 10 & & & & & & & & 10 & 10 & 50 \\
\hline $\begin{array}{l}\text { PONTUAÇÃO } \\
\text { PARCIAL }\end{array}$ & 0 & 75 & 850 & 0 & 0 & 0 & 0 & 0 & 0 & 0 & 1000 & & \\
\hline $\begin{array}{l}\text { PONTUAÇÃO } \\
\text { TOTAL }\end{array}$ & & 925 & & & 0 & & 0 & & & 1000 & & 963 & 100 \\
\hline
\end{tabular}


Também são medidas e registradas durante as manobras, as deformações resultantes dos impactos de atracação sobre as defensas (Figura 26), verificando se o limite de deformação da mesma foi ultrapassado (Figura 27).

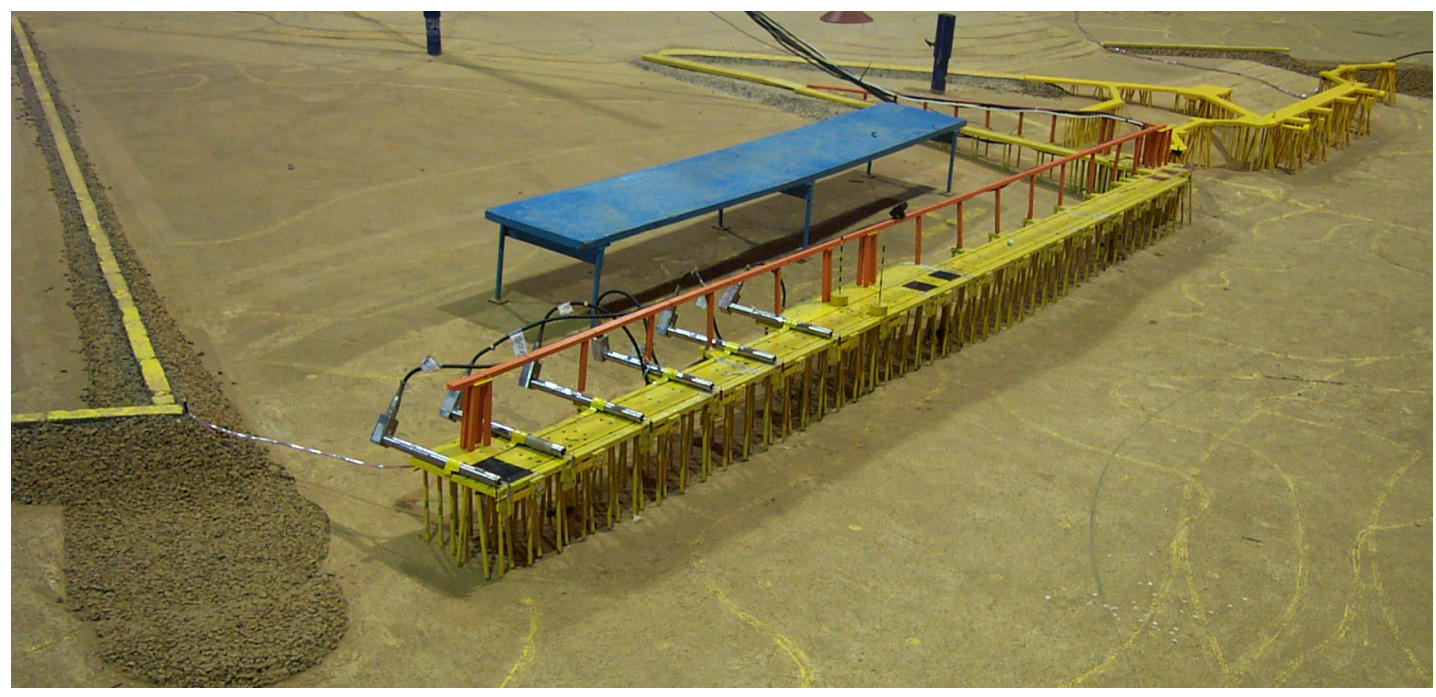

Figura 26: Sensores instalados nas defensas do Píer III, Berço Norte, do PDM (fonte: FCTH, 2005)

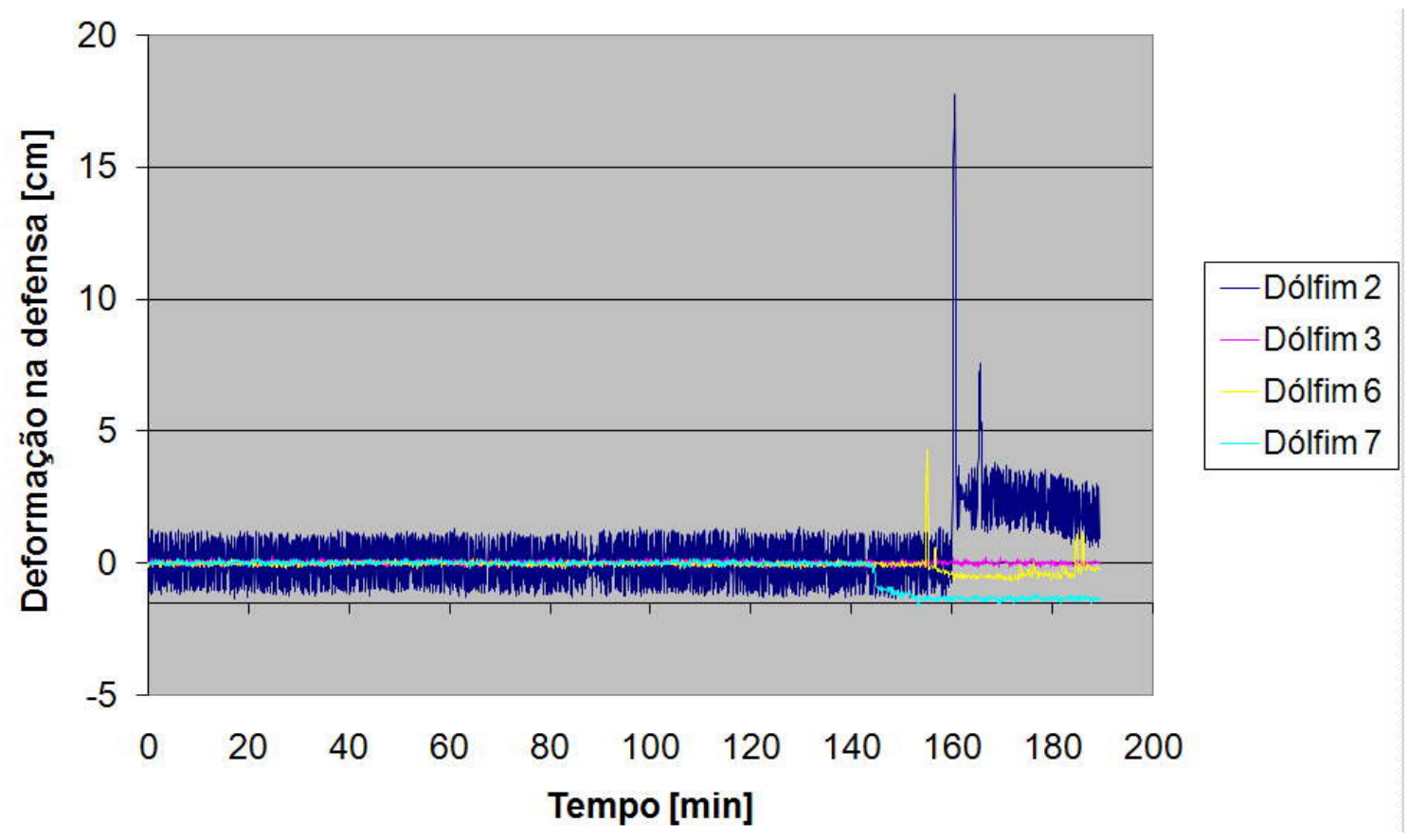

Figura 27: Gráfico das deformações nas defensas, pelo impacto de modelo de navio Capesize no Píer I do PDM (fonte: FCTH, 2007) 
As defensas em todos os berços são calibradas de acordo com a curva de elasticidade (tensão $x$ deformação) das defensas reais, cujas deformações resultantes são registradas durante atracação do navio.

$\underline{\operatorname{SUC2500H}(R S) \times 1 \times 1}$

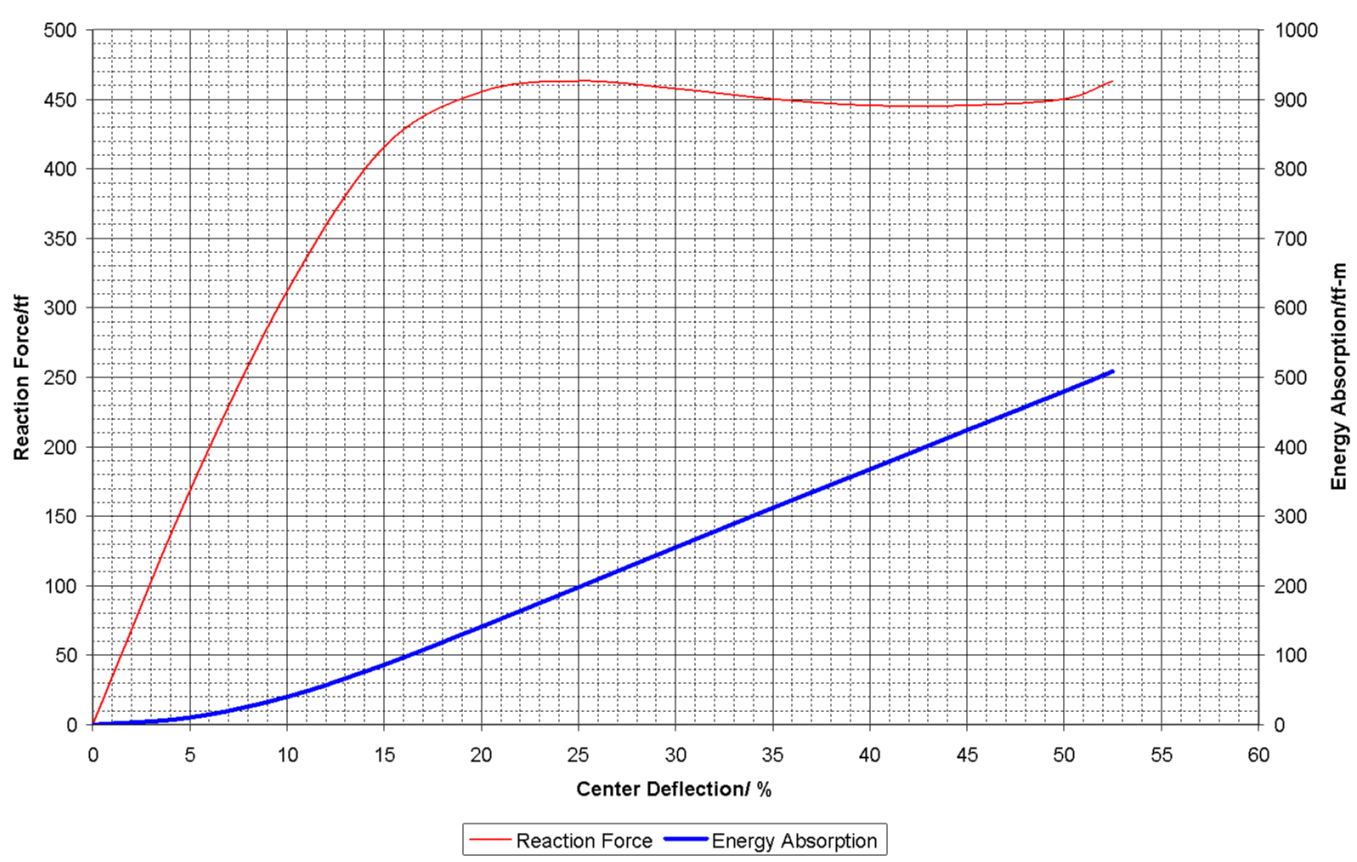

Figura 28: Curva de desempenho da defensa tipo Bridgestone instalada no Píer I do PDM (fonte: Bridgestone, 2008) 


\section{RESULTADOS E GANHOS OBTIDOS NA SIMULAÇÃO DE MANOBRAS DE NAVIOS NO SIAMA}

A técnica da simulação de manobras de navios nos modelos físicos de Terminais Portuários tem por objetivo o aumento do grau de segurança. Possíveis ganhos de produtividade somente são vislumbrados quando há primordialmente condições de segurança operacional.

Neste capítulo foram apresentados os ganhos de segurança e produtividade obtidos com a contribuição do SIAMA nas últimas duas décadas, nos Terminais Portuários da ALUMAR e de Ponta da Madeira/Porto de Itaqui. Deve ser salientado que nesses estudos foi utilizada a mesma bacia do laboratório, adaptando-se o cenário do modelo físico da ALUMAR sobre o de Ponta da Madeira (Figura 33), de modo que quando se ensaiava um cenário, não era possível ensaiar o outro. Não serão

apresentados resultados provindos de estudos no SIAMA do Terminal de llha Guaíba, por não terem sido realizadas manobras oficiais até o momento neste modelo físico.

\subsection{Terminal Portuário da ALUMAR}

Situado na Baía de São Marcos, a oeste da llha de São Luiz do Maranhão e a 10 $\mathrm{Km}$ ao Sul do Porto de Itaqui, na confluência do Rio dos Cachorros com o Estreito dos Coqueiros, o Terminal Portuário da ALUMAR, inaugurado em julho de 1984 (Figura 29), manuseia em operações de descarga granéis sólidos (bauxita, carvão, coque e piche) e líquidos (soda cáustica), necessários aos processos produtivos do Consórcio, e exporta parte da alumina, produzida pela Refinaria e não utilizada na produção de lingotes de alumínio. 


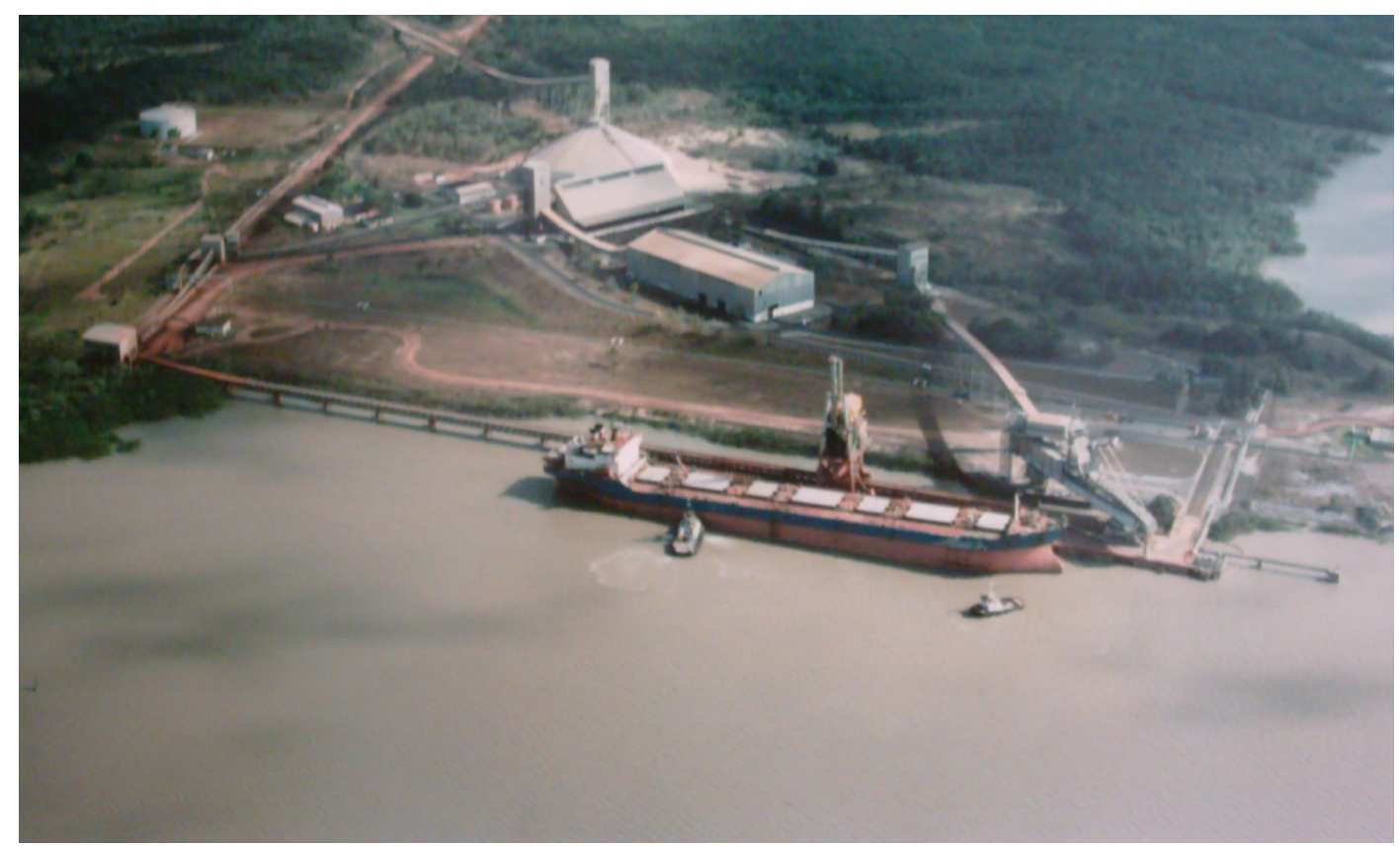

Figura 29: Inauguração do Terminal da ALUMAR em 1984 (fonte: ALUMAR, 2004)

Apesar de dispor de facilidades independentes para operações de carga e descarga de granéis sólidos e líquidos, o Terminal operava inicialmente apenas um navio (do tipo Panamax) por vez, em função de restrições locais existentes e, por sugestão da Praticagem, manobrando apenas à luz do dia, com janelas de manobras bastante reduzidas.

Atualmente (2010), este Terminal está sendo ampliado (Figura 30) para atender à nova demanda de matérias primas para a Refinaria do Consórcio (produção de alumina). As obras de expansão, que contemplam duplicação do píer atual e outras melhorias, visam permitir no futuro operações simultâneas de dois navios no Terminal. 


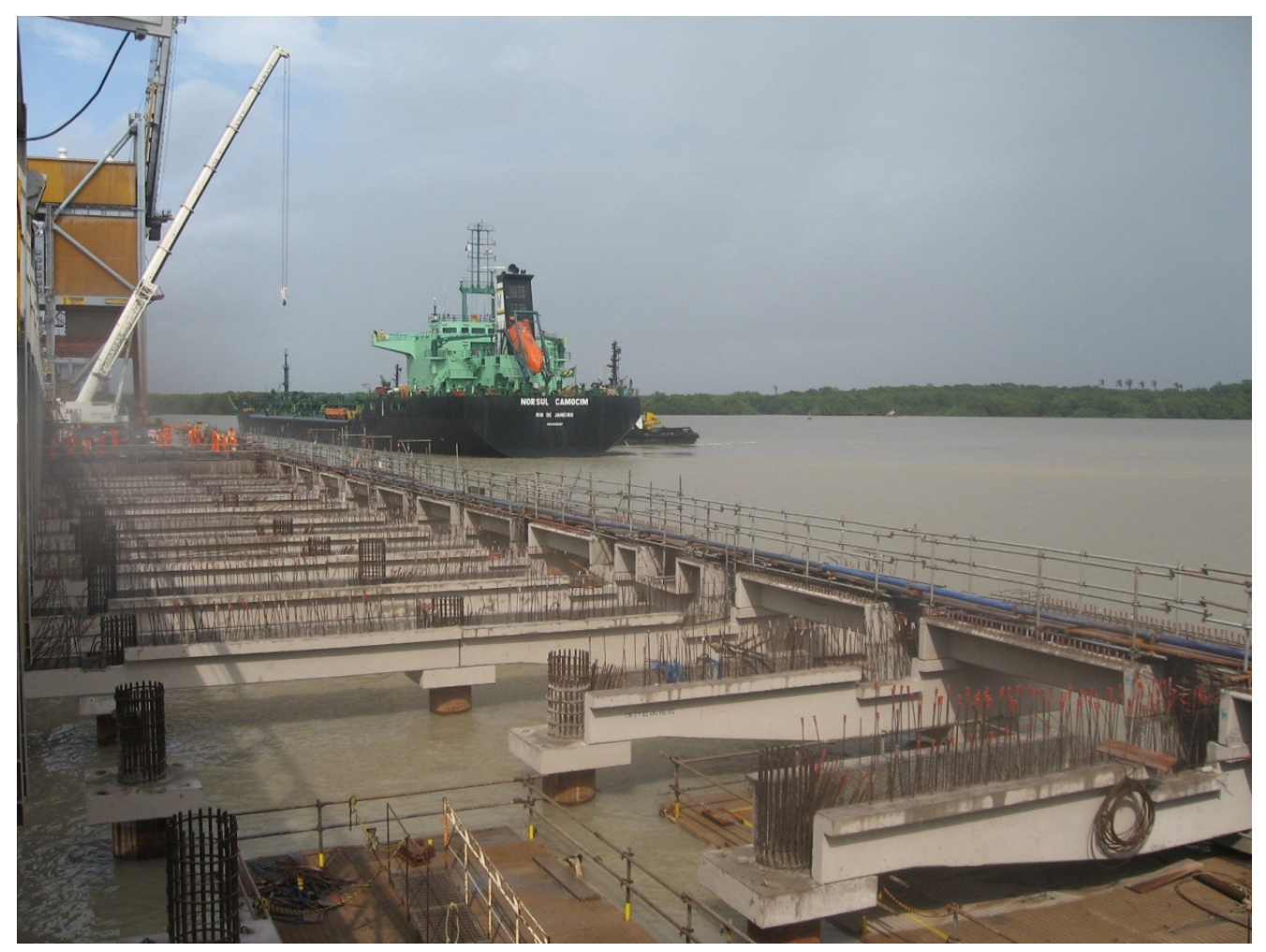

Figura 30: Obras de ampliação do cais da ALUMAR (fonte: foto do autor, 2007)

\subsubsection{Avaliação de manobras visando aumento da janela operacional do Terminal}

De acordo com a norma de operações do Terminal, para atracação de navios com calado entre 6,00 a $10,90 \mathrm{~m}$, os mesmos deverão ter suas manobras iniciadas (Prático a bordo) com 1 hora e 30 minutos antes da preamar. Para a desatracação de navios com calado entre 9,00 e 10,50 m, estes deverão ter suas manobras iniciadas 1 hora antes da preamar. As manobras de atracação e desatracação de navios acima de 50.000 tpb somente podem ser executadas no período diurno, com o auxilio de três rebocadores. Em caso de navios descarregados, podem-se utilizar dois rebocadores. Esses rebocadores devem acompanhar os navios em todo o trajeto do Canal de Acesso balizado do Terminal (ALUMAR, 2004).

Portanto, trata-se de uma regra de manobras bastante restritiva, com janela operacional de, no máximo, três horas por dia. 


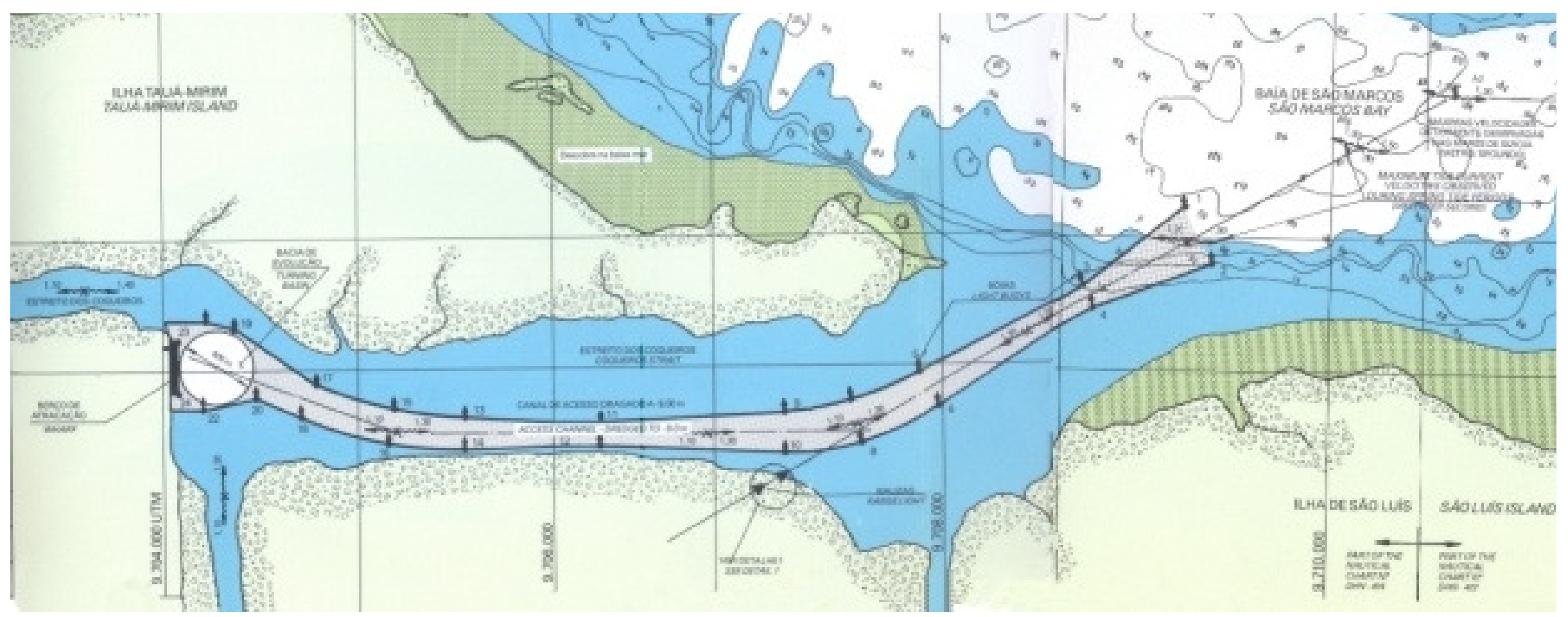

Figura 31: Carta náutica com o Canal de Acesso à ALUMAR (fonte: ALUMAR, 1994). 
Neste capítulo serão apresentados resultados e conclusões sobre as manobras de navios, em função da circulação de correntes de maré reinante no entorno dos berços, considerando a atuação das unidades de reboque, de cabo longo passado, de 50 tf BP, com o intuito de avaliar a viabilidade de ampliação dos horários (janelas de maré), sem contar com rebocadores de maior potência (bollard pull).

A motivação para estes estudos de planejamento portuário pode ser sintetizada como segue:

- Necessidade de aumentar a utilização dos ativos portuários;

- Atender à demanda crescente em menor tempo possível;

- Garantir que todas as manobras sejam feitas com o máximo de segurança possível

- Simular e avaliar as condições de manobras para o novo berço (denominado "expansão lado leste").

No SIAMA foi utilizado o modelo de navio rádio-controlado Panamax, devido à similaridade de suas dimensões com aquelas dos navios usualmente operados no Terminal da ALUMAR (Tabela 12).

Tabela 12: Comparativo entre os navios que operam na ALUMAR e o Panamax

\begin{tabular}{|c|c|c|}
\hline Dimensões & $\begin{array}{c}\text { Navios operados no } \\
\text { Terminal ALUMAR }\end{array}$ & $\begin{array}{c}\text { Modelo de navio } \\
\text { Panamax }\end{array}$ \\
\hline Comprimento total $(\mathrm{m})$ & 225,0 & 242,0 \\
\hline Boca $(\mathrm{m})$ & 32,31 & 32,70 \\
\hline Calado $(\mathrm{m})$ & 10,90 & 10,50 \\
\hline
\end{tabular}

Em resumo, as atividades realizadas, de adaptação, calibração e validação do Simulador analógico de manobras não tripuladas (SIAMA) para os estudos da ALUMAR foram: 
- Levantamento (no acervo ALUMAR), análise e conversão dos dados necessários à calibração, tais como correntometrias, batimetrias, trajetórias de derivadores, dados de marégrafos, cartas náuticas, gabarito geométrico do Canal de Acesso (Figura 31), profundidade de manutenção do canal, dimensões do navio para estudo, bollard pull dos rebocadores, projeto dos cais (antigo e futuro) e de suas fundações, posicionamento das sinalizações náuticas, posicionamento e dimensões da Bacia de Evolução, norma de operação do terminal e regras de manobras do terminal.

- Ajustes das instalações e de dispositivos do SIAMA, visando representar hidrodinamicamente, de forma adequada, o cenário da ALUMAR, contemplando o posicionamento dos limites das áreas modeladas em função do ajuste das vazões e correspondentes velocidades das correntes, de acordo com a calibração e validação com relação ao real.

- Adaptações dos sistemas de alimentação, modulação e restituição do escoamento nas extremidades da área modelada.

- Georreferenciamento no modelo físico com a demarcação das coordenadas cartográficas.

- Verificação da calibração e validação hidráulica do modelo com medições simultâneas de velocidade com uso de micromolinetes em seções hidrográficas de controle e análise de trajetórias de derivadores.

- Ajuste da Instrumentação autônoma do modelo de navio Panamax rádiocontrolado.

- Confecção e implantação da sinalização náutica de bóias e Torres de Alinhamento.

- Confecção dos modelos dos berços de atracação do terminal (Píer lado Leste e Cais de Bauxita) da ALUMAR, incluindo a reprodução das defensas, carregadores e descarregadores de navios (Figura 32). 


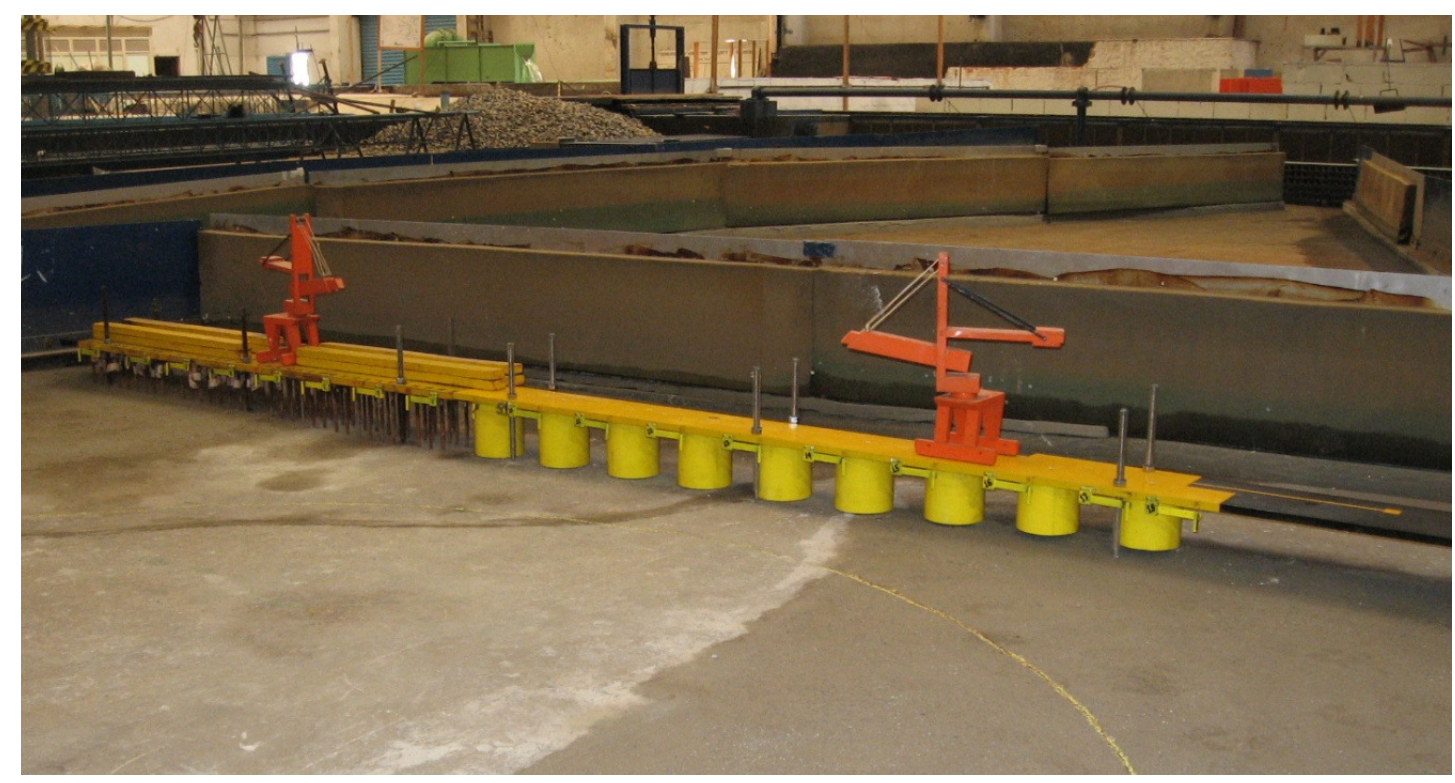

Figura 32: Modelo dos berços implantado no SIAMA (fonte: FCTH, 2008)

O objetivo destes estudos foi o de fornecer ao terminal os subsídios necessários para avaliação das condições de manobrabilidade dos navios para acesso, atracação e desatracação no cais do Terminal da ALUMAR. Foram implantados, no SIAMA, tanto o antigo Cais de Bauxita (em operação desde 1984), quanto a sua expansão para leste. Os ensaios de manobras foram realizados em condições de maré estabelecidas pela norma de operação do Terminal (uma hora ou uma hora e meia antes da preamar), e também em condições ainda não manobradas e inexistentes nas normas de operação do Terminal da ALUMAR, cujos ensaios iniciaram-se por segurança, em condições de proximidades aos estofos das marés.

Foram efetuados ensaios para verificação das condições de atracação e desatracação de navios tipo Panamax em ambos os berços (antigo e novo), em situações com a presença de outro navio atracado (Doce Taurus - $45.000 \mathrm{tpb}$ ) por bombordo no berço oposto ao manobrado e em situações de ociosidade deste.

Dispondo-se do modelo de navio e reprodução de rebocadores instrumentados e calibrados foram efetuados ensaios de manobras conduzidos, no total, por quatro Práticos locais (Figura 33), acompanhados por representantes do Terminal da ALUMAR, e pelo Capitão dos Portos do Maranhão. 
Os ensaios de manobras iniciaram-se pela avaliação da calibração do simulador (na condição de enchente) pelos Práticos presentes. Após a validação da calibração do simulador pelos Práticos, foram realizados ensaios de manobras objetivando-se avaliar a viabilidade de operações na condição de vazante. Todas as manobras realizadas foram objetivamente avaliadas por meio das respostas e comentários preenchendo o questionário. Os Práticos tiveram a oportunidade de se familiarizar com a técnica modelística utilizada e na qual se inseriram, avaliando o campo de correntes com auxílio de confetes e realizando testes de manobrabilidade com os navios antes do início dos ensaios.

Durante os dias de testes e ensaios, a Praticagem, os representantes da ALUMAR, e Capitania dos Portos puderam reiterar diversas manobras, aprimorando a seqüência de comandos dada aos rebocadores, máquina e leme do navio, de modo a torná-los o mais próximos ao procedimento real. As unidades de reboque de cabo longo passado puderam dispor de calibrações equivalentes a 50tf BP, tanto atuando na longitudinal, como combinados na transversal (push-pull). Foram realizados 100 ensaios (com registro de imagens) pelos Práticos (Tabela 13). 


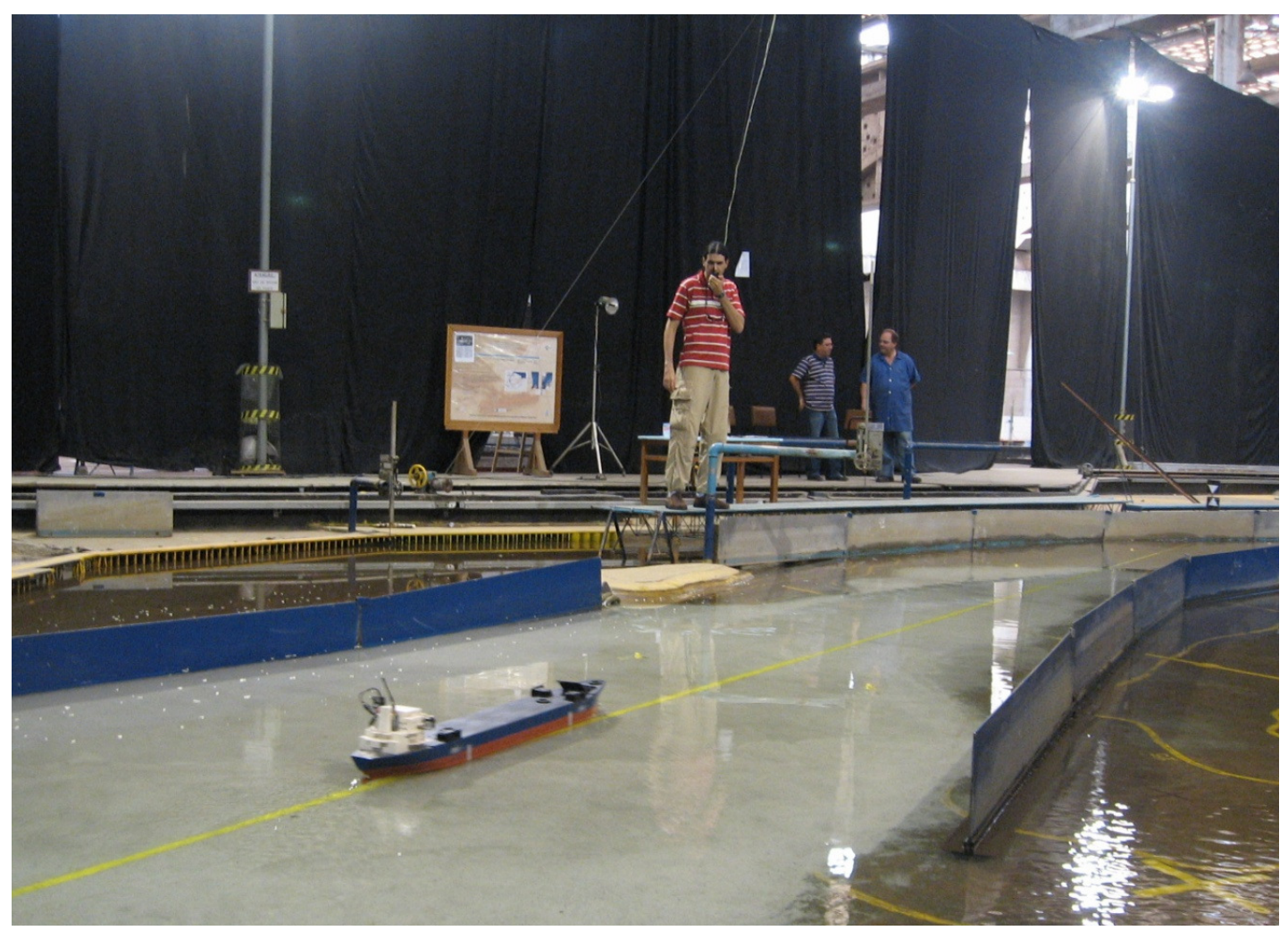

Figura 33: Prático realizando manobra de demanda ao Terminal da ALUMAR pelo Canal de Acesso no SIAMA (fonte: FCTH, 2008)

Os ensaios realizados simularam manobras de acessibilidade, atracação e desatracação em ambos os berços. As manobras foram conduzidas tanto pela visão direta no SIAMA, quanto a partir da visão da imagem projetada a partir de câmara rotatória nas asas de boreste e bombordo do passadiço do modelo de navio.

O modelo de navio Panamax do SIAMA foi ensaiado para diversas condições de calado: $8,0 \mathrm{~m} ; 10,0 \mathrm{~m}$ e $10,5 \mathrm{~m}$. 
Tabela 13: Resumo das manobras simuladas para o Terminal da ALUMAR

\begin{tabular}{|c|c|c|c|c|c|}
\hline \multicolumn{6}{|c|}{ RESUMO DAS MANOBRAS } \\
\hline NAVIO & REBOCADORES & CONDIÇÃO & MANOBRA & CAIS & OBS \\
\hline \multirow{23}{*}{ Panamax } & \multirow{23}{*}{$50 \mathrm{tf}$} & Enchente: 1hAP4,5m & $\begin{array}{c}\text { Atracação por } \\
\text { Bombordo }\end{array}$ & Bauxita & \multirow{4}{*}{$\begin{array}{c}\text { Calado }=10,5 \mathrm{~m} . \mathrm{Na} \\
\text { atracação, giros por } \\
\text { bombordo e por boreste }\end{array}$} \\
\hline & & \multirow[b]{2}{*}{ Enchente:1hAP6,0m } & \multirow{2}{*}{$\begin{array}{c}\text { Atracação por } \\
\text { Bombordo }\end{array}$} & Bauxita & \\
\hline & & & & Leste & \\
\hline & & Enchente: 1hAP5,5m & $\begin{array}{c}\text { Atracação por } \\
\text { Bombordo }\end{array}$ & Leste & \\
\hline & & \multirow{4}{*}{ Vazante: 1hDP6,0m } & \multirow{2}{*}{$\begin{array}{l}\text { Atracação por } \\
\text { Bombordo }\end{array}$} & Bauxita & \multirow{7}{*}{$\begin{array}{c}\text { Calado }=10 \mathrm{~m} . \mathrm{Na} \\
\text { atracação, giros por } \\
\text { bombordo e por boreste }\end{array}$} \\
\hline & & & & Leste & \\
\hline & & & \multirow{2}{*}{$\begin{array}{l}\text { Desatracação } \\
\text { por bombordo }\end{array}$} & Bauxita & \\
\hline & & & & Leste & \\
\hline & & \multirow{3}{*}{ Vazante: 1hDP4,5m } & $\begin{array}{c}\text { Atracação por } \\
\text { Bombordo }\end{array}$ & $\begin{array}{l}\text { Dauxida } \\
\text { Leste }\end{array}$ & \\
\hline & & & \multirow{2}{*}{$\begin{array}{l}\text { Desatracação } \\
\text { por bombordo }\end{array}$} & Bauxita & \\
\hline & & & & Leste & \\
\hline & & Vazante: 2hDP5,0m & \multirow{6}{*}{\multicolumn{2}{|c|}{$\begin{array}{l}\text { Entrada e saída do canal, } \\
\text { com giro por boreste na } \\
\text { bacia de evolução. }\end{array}$}} & \multirow{12}{*}{$\begin{array}{c}\text { Calado }=8 \mathrm{~m} . \text { Com } \\
\text { navio Panamax } \\
\text { atracado no Cais de } \\
\text { Bauxita. Na atracação, } \\
\text { giros por bombordo e } \\
\text { por boreste. }\end{array}$} \\
\hline & & Vazante: 2hDP5,5m & & & \\
\hline & & Vazante: 2hDP6.0m & & & \\
\hline & & Vazante: 1hDP4.5m & & & \\
\hline & & Vazante: 1hDP5,0m & & & \\
\hline & & Vazante: 1hDP5,5m & & & \\
\hline & & \multirow{2}{*}{ Vazante:2hDP4,5m } & $\begin{array}{c}\text { Atracação por } \\
\text { Bombordo }\end{array}$ & \multirow{6}{*}{ Leste } & \\
\hline & & & $\begin{array}{l}\text { Desatracação } \\
\text { por bombordo }\end{array}$ & & \\
\hline & & \multirow{2}{*}{ Vazante:2hDP5.0m } & $\begin{array}{l}\text { Atracação por } \\
\text { Bombordo }\end{array}$ & & \\
\hline & & & $\begin{array}{l}\text { Desatracação } \\
\text { por bombordo }\end{array}$ & & \\
\hline & & \multirow{2}{*}{ Vazante:1hDP6,0m } & $\begin{array}{l}\text { Atracação por } \\
\text { Bombordo }\end{array}$ & & \\
\hline & & & $\begin{array}{l}\text { Desatracação } \\
\text { por bombordo }\end{array}$ & & \\
\hline
\end{tabular}

(AP - Antes da Preamar; DP - Depois da Preamar)

As conclusões abaixo elencadas puderam ser consolidadas após o término dos ensaios e encaminhadas à ALUMAR, Pratimar e Capitania dos Portos.

1) Os Práticos presentes aos ensaios de manobras afirmaram que os ensaios demonstraram a possibilidade de se viabilizar modificações da regra de manobras, no sentido de permitir manobras de atracação e desatracação durante a vazante (uma e duas horas após a preamar), porém ressalvam que há necessidade de um período experimental no real para que se comprovem os resultados observados no SIAMA. 
2) Na Bacia de Evolução não houve grande diferença, nem dificuldade em manobrar com uma ou duas horas depois da preamar. As manobras de atracação no novo cais leste (extensão do cais antigo), com e sem navio atracado no berço adjacente , mostraram-se viáveis.

3) Para acesso ao Terminal da ALUMAR, desde o inicio do canal (bóia ํㅡㄹ) até o Terminal Pesqueiro, situado no trecho intermediário de alinhamento retilínio do Canal de Acesso, não foram observadas dificuldades para manobrar em 1 ou 2 horas após a preamar, porém a partir do Terminal Pesqueiro até a Bacia de Evolução observou-se uma tendência de abatimento do navio para bombordo em decorrência das correntes locais. Os Práticos avaliaram que uma das melhorias vislumbradas para o balizamento do canal é a possibilidade de se deslocar a posição da Bóia no 20 para leste (Figura 31), minimizando, assim, a obliqüidade do canal em relação à Bacia de Evolução, facilitando tanto as manobras de atracação (a popa do navio passa, por vezes muito próxima dessa bóia quando o navio guina para boreste), quanto as manobras de desatracação (é preciso ir para oeste na Bacia de Evolução para se conseguir alinhar com o canal). Ainda segundo os Práticos, outra modificação possível no balizamento passa por deslocar a Bóia ํo 2 (Figura 31) para leste (desde que existam profundidades adequadas), o que diminuiria a exposição do navio às fortes correntes que passam ao largo da entrada do canal da ALUMAR e fazem com que o navio derive em direção à llha Tauá-Mirim (Figura 31).

4) O Capitão dos Portos do Maranhão, após acompanhar os ensaios realizados pelos Práticos no SIAMA, se comprometeu a colaborar com o Terminal visando possibilitar a avaliação no real, em fase experimental, das manobras em condição de vazante que foram realizadas no simulador.

Portanto, conclui-se que a partir da realização dos ensaios de manobras para o Terminal da ALUMAR, é viável aumentar a janela operacional de três para sete horas por dia, além de possibilitar melhorias no balizamento do Canal de Acesso ao Terminal. 


\subsection{Terminal Portuário de Ponta da Madeira / Itaqui}

O Terminal Marítimo de Ponta da Madeira - TMPM está localizado na margem leste da Baía de São Marcos, na llha São Luís, tendo atualmente ao todo três píeres e quatro berços de atracação.

O local foi escolhido devido à profundidade natural da Baía de São Marcos, de mais de $26 \mathrm{~m}$ durante a maré baixa, que permitiria minimizar os custos com dragagem para a atracação de navios graneleiros de grande porte. Ponta da Madeira constitui com o Europoort de Roterdã (local de destino de boa parte dos navios carregados no Terminal), o único conjunto de portos capaz de operar com navios de $23 \mathrm{~m}$ de calado, se não contarmos os terminais petroleiros de alto mar (capazes de operar com navios de até $30 \mathrm{~m}$ de calado).

O TMPM está situado a cerca de oito quilômetros ao sul do centro da cidade de São Luís, capital do Estado do Maranhão, à qual está ligado por rodovia. O TMPM é propriedade da Companhia Vale e é por ela operado e administrado.

O Píer I, com um berço e o Píer III, com dois berços, são instalações portuárias de uso privativo misto, fora da área do Porto Organizado. Já o Píer II, com um berço, é uma instalação portuária de uso privativo misto, dentro da área do Porto Organizado (Empresa Maranhense de Portos - EMAP).

Todos os píeres dispõem de infra-estrutura destinada a receber materiais transportados pela Estrada de Ferro Carajás, e embarcá-los.

Com a finalidade de atenuar as correntes de maré na área de aproximação e atracação, foram construídos dois espigões de enrocamento (espigão Norte e Sul), que abrigam os Píeres I e III (Figura 34). O Espigão Sul tem 312m de comprimento, enraizado na Ponta da Madeira, na cota de $+7,0 \mathrm{~m}$, estando rebaixado para $-2,75 \mathrm{~m}$ (cotas DHN) nos últimos 130m. O Espigão Norte, com comprimento de 1050m, 
ocupa parte da Praia do Boqueirão e, no extremo, tem um Apêndice Defletor de $150 \mathrm{~m}$, construído a $80^{\circ}$ do eixo para o norte.

O Canal de Acesso ao Complexo Portuário de Ponta da Madeira tem 55 milhas náuticas de extensão no alinhamento SSW - NNE.

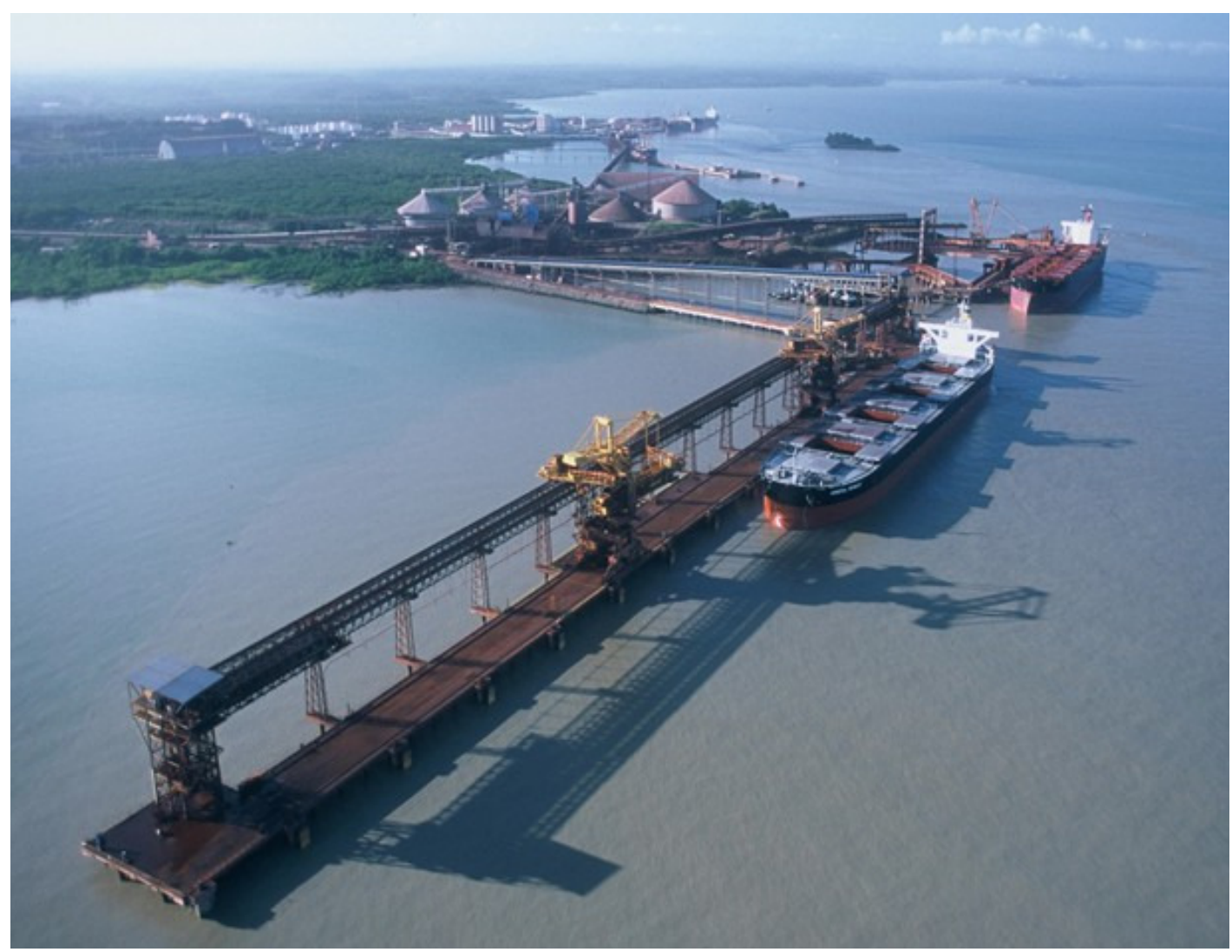

Figura 34: Imagem aérea do Píer III em primeiro plano e do Píer I ao fundo (fonte: CVRD, 2004)

Está prevista para 2012 a construção de mais um píer, denominado Píer IV, com dois berços para navios de até 400.000 tpb.

\subsubsection{Avaliação de situações de desatracação de emergência nos Píeres I e III}

O objetivo destes estudos foi o de fornecer aos inspetores do Complexo Portuário subsídios básicos necessários ao entendimento sobre o comportamento de navios Capesize (150.000 tpb) que tenham rompido seus cabos de amarração nos Píeres I 
e III (Berço Norte) e que, numa situação de emergência, dependam de atitudes de governo imediatas na desatracação, para que a situação não evolua para um acidente de maiores proporções, enquanto não assume o controle da situação um Prático da localidade. Situações semelhantes às reproduzidas ocorreram em dezembro de 2004, quando do acidente do navio Savina (classe Capesize) no Píer I, ocasião em que numa vazante de sizígia romperam-se inicialmente os springs de ré, e do navio Kamari (classe Panamax) no Píer III, em que na mesma sizígia em enchente romperam-se os cabos traveses ao norte.

Neste item foram apresentados os resultados e conclusões sobre as manobras de desatracação de emergência de navios, considerando a atuação da máquina e leme, nos primeiros estágios, e das unidades de rebocadores de 50 (unidades originais) e 75 tf de Bollard Pull. Com estas verificações procurou-se avaliar a viabilidade e a dificuldade de conter maiores movimentações inerciais do navio num período crucial entre a ruptura dos cabos e a chegada do Prático, o que pode ser estimado em 1 hora, para assumir o controle da manobra.

A motivação para os estudos foi sintetizada como:

- Necessidade de aumentar o conhecimento que os inspetores detêm sobre a hidrodinâmica reinante em condições extremas de emergência, que possam pôr em risco a integridade do sistema de amarração do navio.

- Necessidade dos inspetores visualizarem de forma integrada a interação hidrodinâmica entre a circulação de correntes maré, o navio (atuação da máquina e leme) e a atuação dos rebocadores.

- Garantir que a situação de emergência de desatracação decorrente de ruptura dos cabos possa ser mantida sob controle, preservando a integridade do navio e do píer, até que as condições críticas de correntes amainem, bem como com a chegada de um Prático para conduzir a manobra de emergência. 
Os ensaios de manobras de desatracação de emergência foram realizados com navios atracados nos berços com a seguinte disposição:

- Píer I: Capesize (150.000 tpb), ou sem navio

- Berço Sul do Píer III: Capesize (150.000 tpb), ou sem navio

- Berço Norte do Píer III: Capesize (150.000 tpb)

Nas manobras foi utilizado o modelo de navio Capesize do SIAMA com 17,6m de calado (carregado).

A amarração do Capesize instrumentado nos píeres foi efetuada com um sistema fusível, não modelando quantitativamente a rigidez dos cabos, que permitisse facilmente simular a ruptura de cabos de interesse (springs de ré no Píer l e traveses ao norte no Píer III), à qual se segue a ruptura dos demais cabos.

Dispondo-se do modelo de navio e reprodução de rebocadores instrumentados e calibrados, foram efetuados 80 ensaios de manobras de desatracação de emergência, sob a supervisão do Capitão do Porto do Terminal. Com o subsídio destes ensaios, os inspetores puderam dispor de uma visualização quanto às dificuldades destas condições de manobras.

Por ocasião dos ensaios foram discutidos, além da melhor estratégia de manobra perante diferentes condições de maré, os diferenciados aspectos que implicam na segurança da navegação.

Durante os dias de ensaios os inspetores e o Port Captain do Terminal puderam reiterar diversas manobras de desatracação de emergência (Figura 35), aprimorando a seqüência de comandos dada aos rebocadores, máquina e leme do navio. Visando avaliar comparativamente a influência do Bollard Pull, as unidades de rebocadores puderam dispor de calibrações de 20,30,45, 60, 75 e 100 tf, visando 
definir qual a faixa desejável, em termos de custo/benefício para melhor atender situações de manobras de emergência.

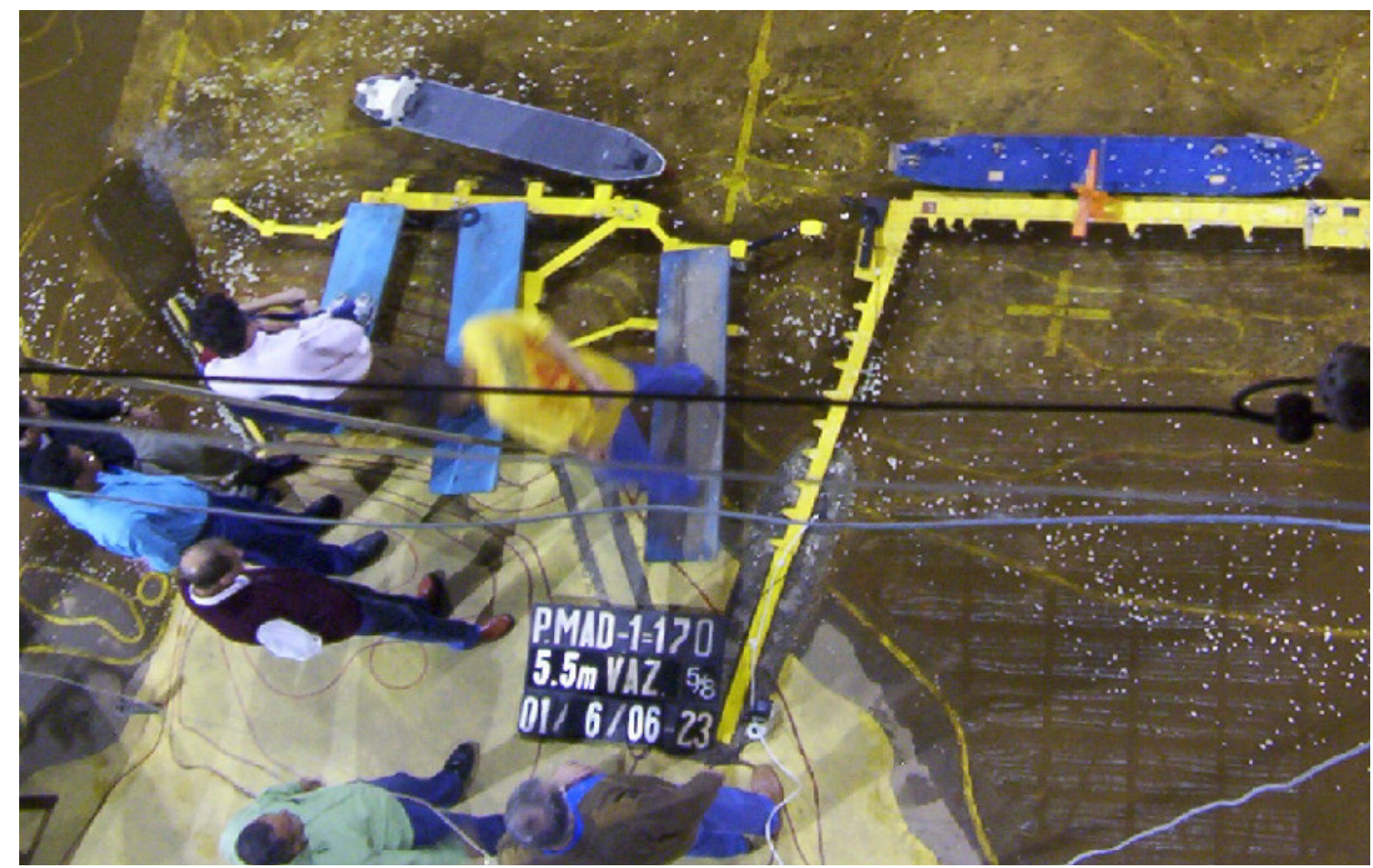

Figura 35: Imagem zenital dos ensaios de desatracação de emergência (fonte: FCTH, 2004)

Os ensaios de manobras de desatracação de emergência com navio Capesize simularam condições de enchente, no Berço Norte do Píer III, e vazante no Píer I. As manobras foram conduzidas pela visão direta no SIAMA.

As condições avaliadas foram:

- Em maré enchente: horário de $3 \mathrm{~h}$ antes da preamar de amplitudes de 6,5 e 6,0 m

- Em maré vazante: horário de 4 h após a preamar de amplitudes de 6,5 e 6,0 m.

As desatracações foram efetuadas por boreste no Píer I e por boreste e bombordo no Berço Norte do Píer III.

As conclusões definidas a partir destes ensaios foram: 
1) Ficou evidente que a definição da migração da estratégia de conter o navio no píer, ou desvinculá-lo totalmente e afastá-lo, as quais devem ser nitidamente distintas (não se admitindo meio termo) enquanto as condições de correntes forem desfavoráveis, dependem do nível de contenção do esforço inercial do navio. Quando for possível inibir preventivamente o esforço inercial, prevendo uma situação de emergência pelas condições de amarração do navio face as correntes, a primeira estratégia pode contemporizar a situação; caso contrário, em que a inércia já produziu importantes acelerações aos movimentos, convém optar pela segunda estratégia, situação em que é fundamental a possibilidade de largar todos os cabos nos ganchos de desengate rápido.

2) Recomendação, pelas considerações acima, que os sistemas de desengate rápido dos cabos e o monitoramento no píer dos movimentos e esforços de atracação sejam mantidos e implementados para auxílio da Inspetoria na tomada de decisões preventivas a situações de maior risco. A documentação das condições de atracação em tempo real constitui-se em acervo documental importante para a descrição do comportamento dos navios.

\subsubsection{Estudo das condições de manobras de navios no projetado Cais 108 da EMAP}

Os estudos foram conduzidos no SIAMA com a finalidade de se fornecer informações necessárias para o projeto detalhado das obras portuárias para um novo cais da EMAP, aonde se pretenderia instalar o Terminal de Petróleo nas vizinhanças do Píer I.

A locação original deste cais situava-o como uma extensão ao Cais 106, justaposto ao Espigão Sul, cuja soleira terminal fora arrasada em 1987, visando melhoramentos das condições de abrigo do Píer I (Figura 36). 


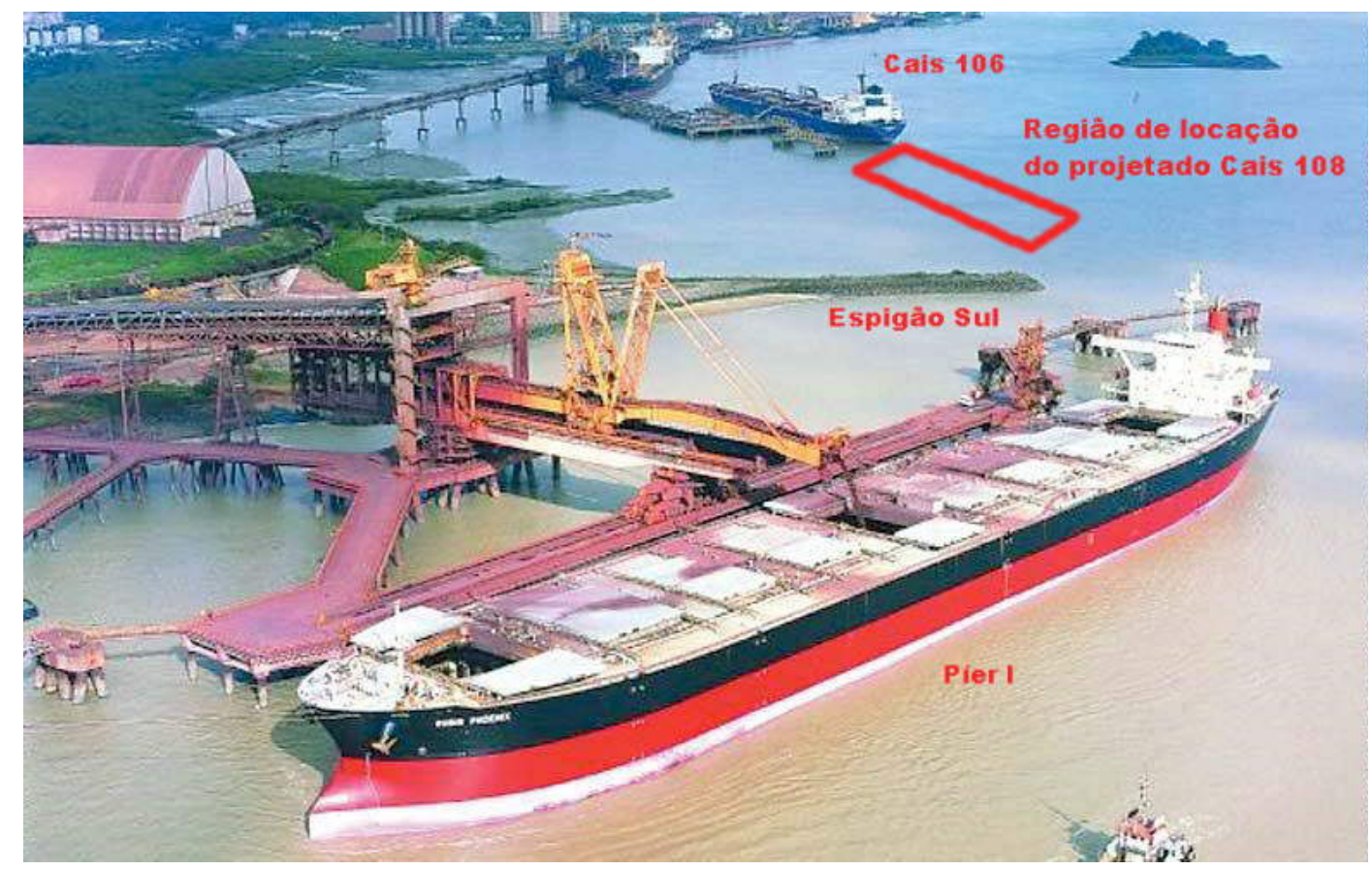

Figura 36: Imagem aérea do Píer I em primeiro plano e Porto de Itaqui ao fundo (fonte: CVRD, 2001)

A área escolhida da enseada entre Itaqui e Ponta da Madeira está sujeita a fortes correntes de maré na condição de vazante, as quais sofrem acentuado desvio para o largo exatamente na porção mais ao norte desta enseada, aonde se pretenderia instalar o referido Cais 108. Dessa forma o estudo foi realizado segundo diretrizes a favor da segurança, uma vez que suas estruturas portuárias projetadas são parcialmente desabrigadas, e que não acarretassem impactos negativos sobre obras já existentes. Dentro da programação os estudos de manobras foram efetuados em duas etapas:

1aㅡ etapa: Fase de ensaios sobre desatracação espontânea de navios Handysize (45.000 tpb) do arranjo geral original do Cais 108 do Porto de Itaqui da EMAP e sua repercussão sobre o Píer I da Companhia Vale.

$2^{a}$ etapa: Fase de ensaios de manobras de atracação e desatracação no arranjo geral original do Cais 108.

Neste item foram apresentados os resultados e conclusões quanto ao comportamento dos navios em função da circulação de correntes de maré reinante 
no entorno do berço, bem como as manobras de atracação e desatracação, e testes de desatracação espontânea dos navios.

Abaixo estão relacionados os serviços realizados para adaptação do SIAMA para o estudo de manobras:

- Desenho e confecção dos modelos das estruturas do Cais 108;

- Implantação de dragagem na cota - 14,00 m à frente dos berços 100 a 103 da EMAP;

- Confecção e calibração das defensas para o Cais 108.

Os ensaios de manobras foram realizados com navios atracados nos berços com a seguinte disposição:

- Píer I: Berge Stahl (365.000 tpb) atracado por boreste;

- Cais 106 da EMAP: Doceriver (150.000 tpb) atracado por bombordo

O modelo de navio Post Panamax utilizado nas manobras tinha $11,0 \mathrm{~m}$ de calado, correspondendo a $55.000 \mathrm{tpb}$.

Dispondo-se do modelo de navio instrumentado e calibrado foram efetuados ensaios de manobras, na presença de Práticos da região e de representantes dos Terminais.

Por ocasião dos ensaios foram discutidos, além da melhor estratégia de manobra perante diferentes condições de maré, os diferenciados aspectos que implicam na segurança da navegação sob as considerações de procurar atingir-se a maior produtividade com segurança.

As manobras efetuadas pelos Práticos foram objetivamente avaliadas por meio das respostas e comentários preenchendo o questionário. Durante os dias de testes e 
ensaios a Praticagem pode reiterar diversas manobras, aprimorando a seqüência de comandos dada aos rebocadores, máquina e leme do navio, de modo a torná-los o mais próximos ao procedimento real. Foram realizados ao todo 62 ensaios. Todas as manobras foram registradas em vídeo e fotografadas para acervo (Figura 37).

Os ensaios de manobras com navio Panamax no Cais 108 simularam manobras de atracação e desatracação em condições de enchente e vazante. As manobras foram conduzidas tanto pela visão direta no SIAMA, quanto a partir da visão da imagem projetada a partir de câmara rotatória na asa de boreste do passadiço do modelo de navio.

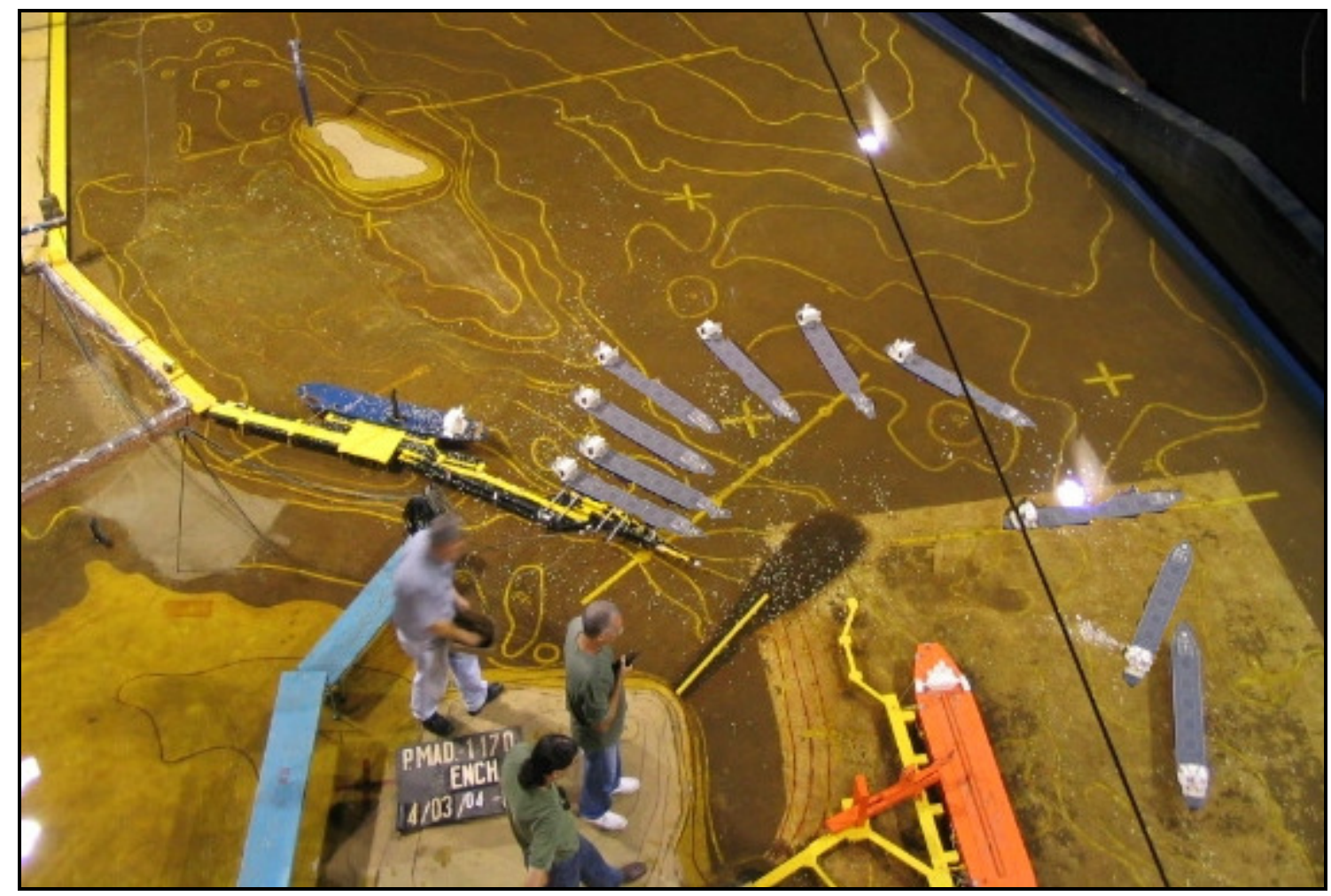

Figura 37: Imagem zenital de manobra de atracação à ré no Cais 108 (fonte: FCTH, 2005)

Foram efetuadas manobras sem giro e com giros de evolução para a atracação, mesmo sabendo-se que a área de giro real encontra-se fora do limite do SIAMA, e que este procedimento no modelo forçosamente se traduz numa manobra em que o navio se aproxima demasiadamente do terminal e distorce o campo de correntes junto ao limite artificial oeste do SIAMA. 
As conclusões oriundas desses ensaios foram:

1) Sendo a área do cais desabrigada na vazante e confinada, além de tratar-se de berço para operação de inflamáveis (carga de risco), a operação deveria ser liberada inicialmente para navios até o porte bruto de $45.000 \mathrm{tpb}$. Para navios entre $45.000 \mathrm{e}$ 75.000 tpb sugeriu-se que a operação somente deveria ser iniciada após um suficiente período de operação, que disponibilizasse um histórico do comportamento de atracações com navios até 45.000 tpb.

2) Foi detectado que no caso de desgarramento de navio, por ruptura ou excesso de esforço em um ou mais cabos, o risco de colisão com o Espigão Sul na vazante tem probabilidade superior a $70 \%$ da amostra ensaiada. Sendo assim, torna-se imprescindível neste contexto, a presença de rebocadores aptos a atender prontamente emergências neste cais.

3) No âmbito das condições de ensaio utilizadas nas verificações de manobras de atracação e desatracação, que corresponderam às de um navio de 55.000 tpb, pode-se inferir que nas desatracações não foram sentidas dificuldades. A principal dificuldade notada consiste na atracação, no momento da finalização do giro na Bacia de Evolução e na estabilização desta posição, que se situa entre o Espigão Sul e a llha de Guarapirá. Uma vez o navio situando-se na área abrigada pelo espigão, a manobra decorre sem maiores dificuldades.

O espaço físico disponível entre o Cais 106 e o Espigão Sul é da ordem de 370 m entre o espelho de popa de um navio Capesize atracado e a saia do offset do enrocamento do Espigão Sul. Considerando as folgas necessárias para as manobras de atracação e desatracação e restrições de profundidade para o calado dos navios no trecho mais próximo do Espigão Sul, o maior navio recomendado para ocupar um berço nesta área estaria entre as classes Handysize e Panamax, isto é em torno às 45.000 tpb 


\subsubsection{Aprovação da ampliação do Píer III para receber dois navios Capesizes}

Em função do aquecimento do mercado internacional para seus produtos, em 2001 a empresa responsável pelo TMPM vendeu antecipadamente uma grande quantidade de ferro, manganês e outros minérios, e para isso precisava ampliar sua capacidade de embarque, de 56 para 85 milhões de t/ano, o que exigiria o carregamento simultâneo de dois navios com capacidade para 180.000 toneladas no Píer III, sendo necessária uma ampliação em mais 65 metros de extensão (passando de 571 para 636 metros).

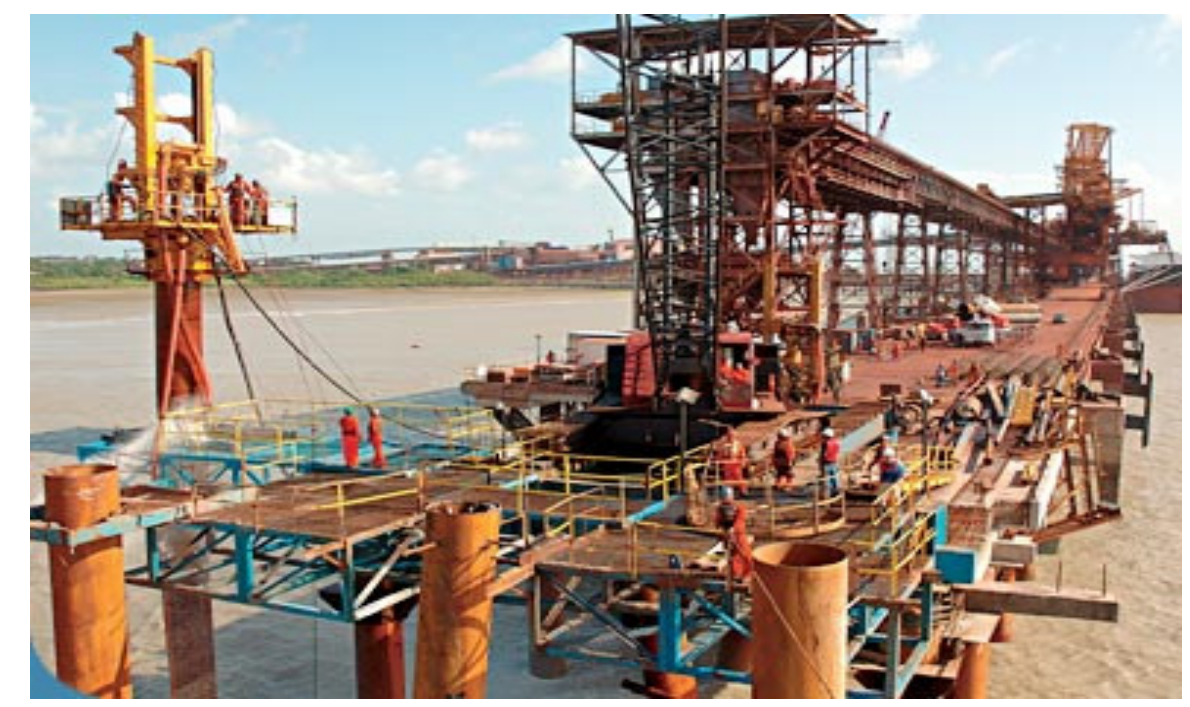

Figura 38: Execução da obra de expansão do Píer III (fonte: CVRD, 2004)

Os estudos de manobras no SIAMA visavam fornecer à Companhia interessada na ampliação, informações necessárias para que o projeto básico das obras portuárias de ampliação permitisse a acomodação de dois navios Capesizes, segundo diretrizes seguras, uma vez que as estruturas portuárias estudadas ficariam parcialmente desabrigadas em seu extremo norte, e que não acarretassem impactos negativos sobre obras já existentes.

Os ensaios de manobras no SIAMA foram realizados com navios atracados nos berços com a seguinte disposição:

- Píer I: Berge Stahl (365.000 tpb) atracado por boreste 
- Berço Sul do Píer III: Doceriver (150.000 tpb) atracado por boreste.

O modelo de navio Capesize utilizado nas manobras de atracação teve $11,0 \mathrm{~m}$ e $9,0 \mathrm{~m}$ de calado na proa e $12,0 \mathrm{~m}$ e $13,5 \mathrm{~m}$ na popa.

Durante quatro dias de testes e ensaios a Praticagem pode reiterar diversas manobras, aprimorando a seqüência de comandos dada aos rebocadores, máquina e leme do navio, de modo a torná-los o mais próximos ao procedimento real. Foram realizados ao todo 74 ensaios. Todas as manobras foram registradas em vídeo e fotografadas para acervo (Figura 39 e Figura 40).

Os ensaios de manobras com navio Capesize simularam atracações e desatracações em condições de enchente e vazante. As manobras foram conduzidas tanto pela visão direta no SIAMA, quanto a partir da visão da imagem projetada a partir de câmara rotatória na asa de boreste do passadiço do modelo de navio.

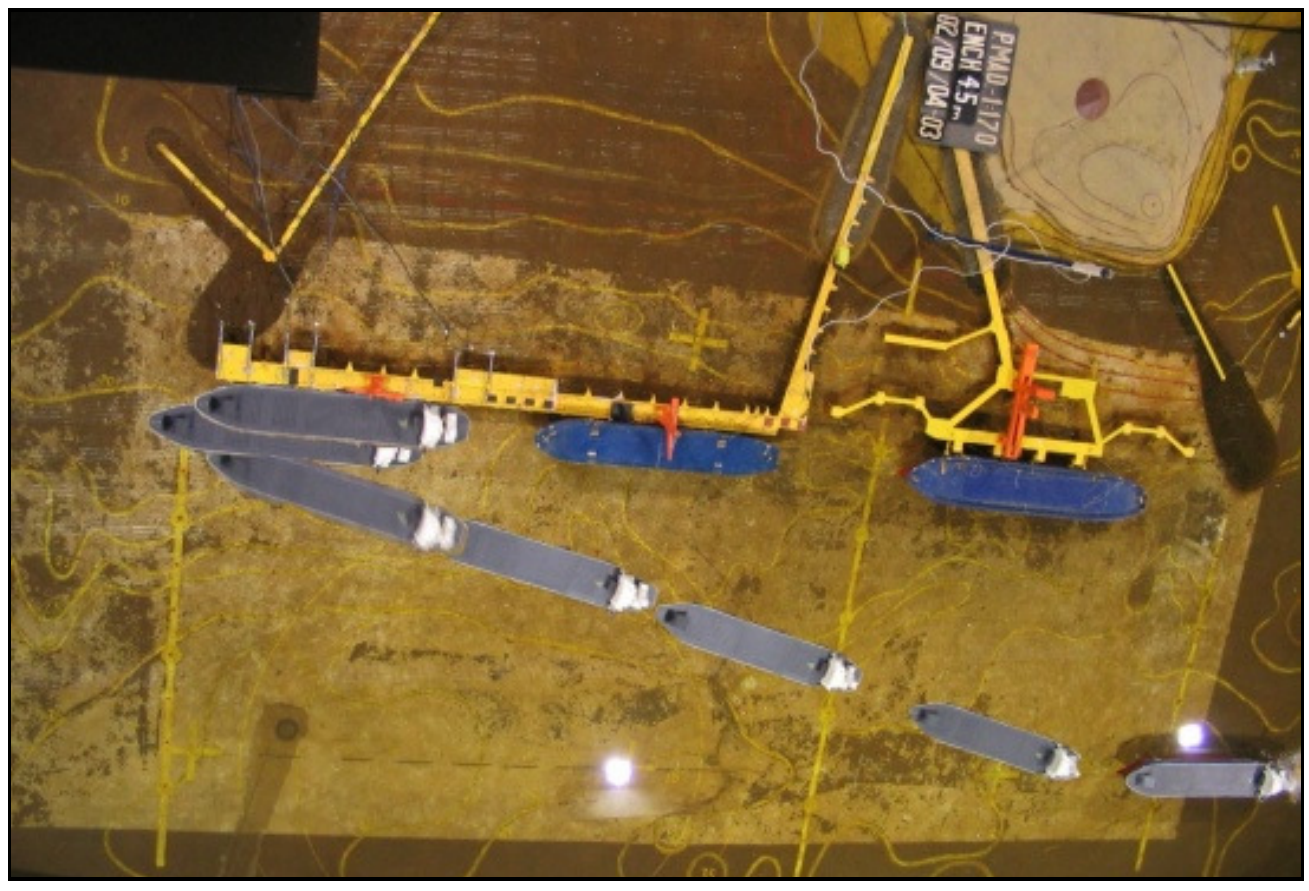

Figura 39: Atracação por boreste no Píer III Norte (fonte: FCTH, 2001) 
As condições hidráulicas avaliadas foram: horários de $1 \mathrm{~h}$ e $1 / 2 \mathrm{~h}$ antes da preamar e baixa-mar e amplitudes de 4,5, 5,5, 6,0 e 6,5 m. As atracações foram efetuadas por boreste e bombordo, bem como as desatracações.

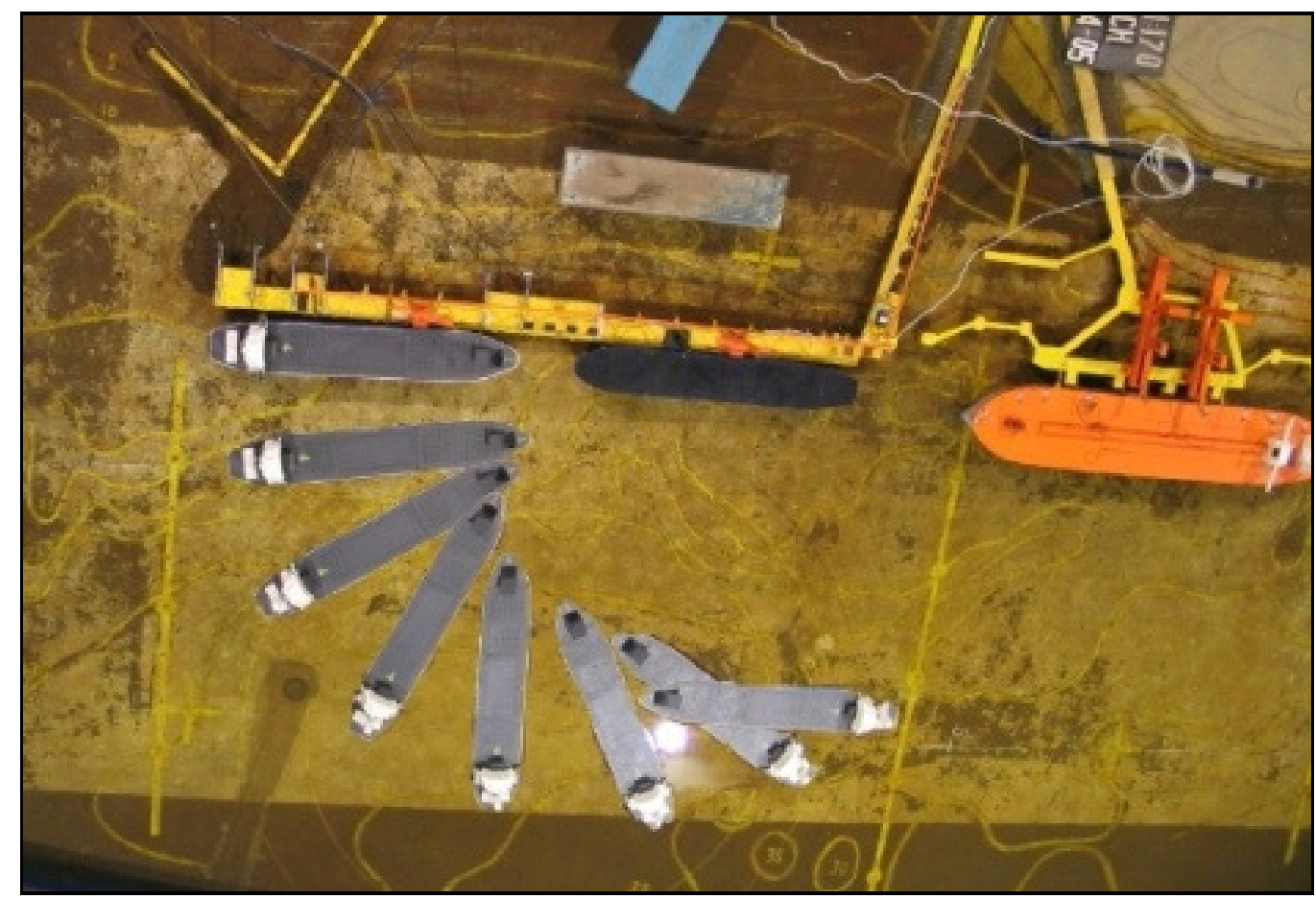

Figura 40: Atracação por bombordo com giro por bombordo no Píer III Norte (fonte: FCTH, 2001)

No âmbito das condições de ensaio utilizadas nas verificações de manobras de atracação e desatracação, pode-se concluir que:

1) Foi aprovada pela Praticagem, em função das manobras realizadas no simulador, a ampliação do Berço Norte para acomodar a atracação de dois navios Capesizes no Píer III. O avanço do extremo norte do navio atracado no Berço Norte em 65 m para o norte ainda permite condições seguras de atracação e desatracação neste berço.

2) As atracações por boreste no Berço Norte em sizígia demonstram-se viáveis no período a partir de 1 hora antes da preamar, assim como as desatracações. 
3) As atracações por bombordo no Berço Norte mostraram-se viáveis no período a partir de 1 hora antes da baixa-mar, representando a possibilidade de ampliar a operação que era efetuada até o porte de 80.000 tpb para o porte de 180.000 tpb.

4) As desatracações por bombordo no Berço Norte são efetuadas de forma mais favorável executando-se o giro por bombordo, comparativamente ao giro por boreste, nas condições de enchente. Em maré vazante o giro deve ser efetuado por boreste.

\subsubsection{Avaliação de manobras com navios ULOCs no projetado Píer IV}

No ano de 2004 foram realizados ensaios de manobras para avaliar condições operacionais de navios ULOCs (Ultra Large Ore Carrier), com capacidade de 575.000 tpb, no projetado Píer IV, que será construído a NNW do Píer III, em área desabrigada e inicialmente projetada com apenas um berço de atracação.

A possibilidade de contar com novas obras de abrigo não foi recomendada no projeto, em virtude dos efeitos colaterais de sedimentação e geração hidrodinâmica de recirculações que poderiam produzir fenômenos pulsatórios adversos, semelhantes aos já conhecidos no entorno da ponta da Madeira..

O estudo de locação e posicionamento do Píer IV envolveu três alternativas distintas de locação:

$1^{\underline{a}}$ alternativa: Linha de atracação na profundidade de 20,0m (DHN), exigindo $150.000 \mathrm{~m}^{3}$ "in situ" de dragagem de implantação na cota -26,0 m (DHN) com talude de $1 \mathrm{~V}: 6 \mathrm{H}$.

$2^{\mathrm{a}}$ alternativa: Exigiria $35.000 \mathrm{~m}^{3}$ "in situ" de dragagem de implantação na cota $-26,0$ $\mathrm{m}(\mathrm{DHN})$ com talude de $1 \mathrm{~V}: 6 \mathrm{H}$. 
3a alternativa: Linha de atracação na profundidade - 23,0 m (DHN), exigindo 5.000 $\mathrm{m}^{3}$ "in situ" de dragagem de implantação na cota -26,0 m (DHN) com talude de $1 \mathrm{~V}$ : $6 \mathrm{H}$.

Durante os estudos de locação cogitava-se a possibilidade de implantar um berço interno, além do externo no referido píer.

$\mathrm{Na}$ definição do posicionamento do Píer IV, além do volume que teria que ser dragado para atingir o gabarito geométrico foi levado em consideração o impacto da presença deste píer nas manobras nos berços existentes, em especial o Berço Norte do Píer III, por estar mais próximo do novo píer. Buscou-se deslocar mais para o norte o novo píer, quanto mais externo fosse seu posicionamento, de forma que fosse possível desatracar os navios do Píer III com o mínimo risco de colisão com o novo píer.

A partir de estudos realizados em modelo numérico, avaliou-se preliminarmente a direção das correntes para cada posição para servir de referência para o alinhamento do píer.

No estudo em modelo físico foram simulados os esforços na amarração dos navios supracitados a plena carga, para diversas condições de maré para as três alternativas propostas, sendo a primeira alternativa mais adequada em termos de esforços sobre os cabos de amarração dos navios.

A partir de então, iniciaram-se os ensaios de manobras, incluindo as manobras com navio ULOC, para o Píer IV locado na primeira alternativa.

Abaixo estão relacionados os serviços realizados para adaptação do SIAMA para o estudo:

- Desenho, confecção e implantação do píer, bem como suas estacas. 
- Confecção de dois modelos do navio ULOC em fibra de vidro: casco nu e instrumentado.

- Confecção e calibração das defensas para o Píer IV.

- Preparo dos modelos de navios para ensaios: instalação dos guinchos e buzinas nos conveses.

Os ensaios de manobras foram realizados sem e com a presença de navios atracados nos demais berços com a seguinte disposição:

- Píer I: navio Berge Stahl (365.000 tpb) atracado por boreste

- Píer III Sul: navio Capesize (150.000 tpb) atracado por boreste.

Os modelos de navios instrumentados utilizados durante as manobras foram o ULOC (Figura 41), Berge Stahl e Capesize.

Por ocasião dos ensaios foram discutidos, além da melhor estratégia de manobra perante diferentes condições de maré, os diferenciados aspectos que implicam na segurança da navegação sob as considerações de procurar atingir-se a produtividade com segurança. 


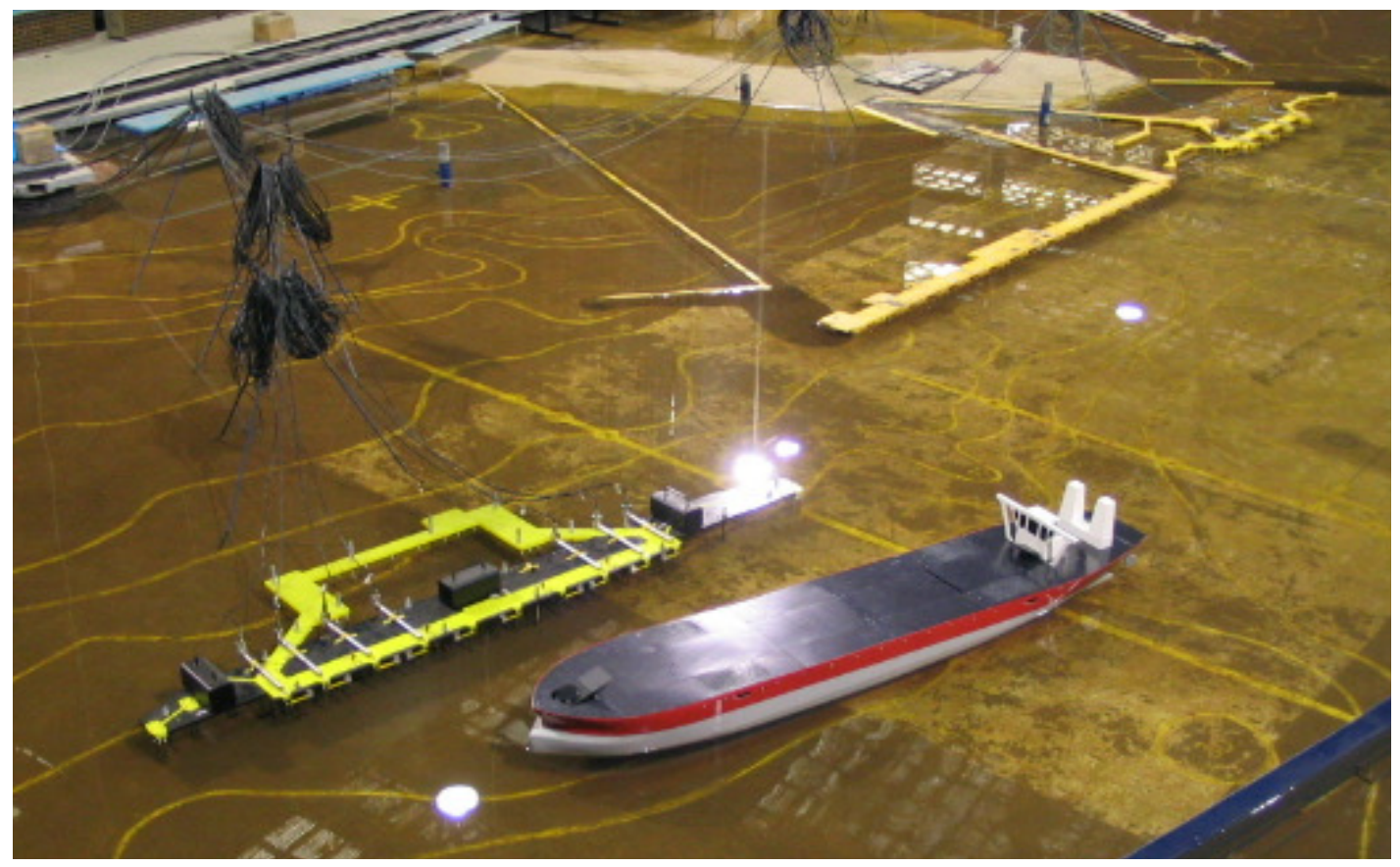

Figura 41: Atracação do navio ULOC no Píer IV (fonte: FCTH, 2006)

As manobras foram efetuadas numa primeira etapa, em que foram utilizados os modelos dos navios Berge Stahl e Doceriver em lastro, visando formar uma referência de condições para comparação das atracações no Píer IV. As condições de maré utilizadas foram de enchente (1/2, 1 e 1 1/2 horas antes da preamar) com amplitude de 6,0 m; e de vazante (1/2 hora após a preamar) de 6,0 $\mathrm{m}$ de amplitude. As atracações foram efetuadas por boreste, reproduzindo a aproximação após giro. Ao todo foram realizados 16 ensaios, que foram avaliados por questionário específico.

Numa segunda etapa as manobras foram conduzidas com o modelo do navio ULOC, verificando-se as condições de atracação e desatracação nos píeres IV e I. As condições de maré utilizadas foram de enchente (1 hora antes da preamar) com amplitudes de $5,5 \mathrm{~m}$ e $6,5 \mathrm{~m}$. As atracações foram efetuadas por boreste nos píeres IV e I, reproduzindo a aproximação após giro. Ao todo foram realizados mais de 50 ensaios e testes, os quais permitiram estabelecer as seguintes conclusões:

1) Haveria necessidade de aumento da potência dos rebocadores do Terminal, acima da condição de "bollard pull" dos equipamentos que operam com o navio 
Berge Stahl carregado no Europoort, uma vez que as condições em Rotterdam são mais abrigadas do que no Píer IV. As atracações e desatracações no Píer IV exigiram forças da ordem de $90 \mathrm{tf}$ (efetivas sobre o navio) para que houvesse segurança de manobra com quatro rebocadores, sem ter que se recorrer ao uso da máquina do navio. Sob este aspecto, também preocupou a possibilidade de ocorrência de situações de emergência com navios deste porte no Canal de Acesso, uma vez que não havia informações sobre a sua capacidade de governo em águas rasas em testes em modelos em maior escala.

2) Recomendou-se fortemente que para a condução do projeto do ULOC deveria ser envolvida também uma frota de rebocadores específica.

3) Necessidade de serem estudadas áreas de fundeio específicas para o ULOC.

4) Foi definitivamente descartada a possibilidade de existir um berço interno neste píer, pois além dos resultados ruins dos estudos de amarração, a manobra se mostrou extremamente complexa, inclusive com alto risco de colisão com a ponte de acesso.

5) O posicionamento adotado não comprometia as manobras de atracação e desatracação do Píer III, desde que fossem executadas exaustivamente manobras com a participação de todos os Práticos locais no SIAMA, antes de executá-la no real.

\subsubsection{Estudo de manobras para o Pólo Siderúrgico de São Luiz}

Em abril de 2002 a Companhia Vale e a empresa chinesa de siderurgia Baosteel assinaram memorando de entendimentos para construção de usina de placas em São Luis. O projeto do Terminal da usina previa sua implantação cerca de $300 \mathrm{~km}$ ao Sul do Porto de Itaqui (ver Figura 42). A opção dos investidores pelo Maranhão levou em conta, a vocação natural do estado, a proximidade da mina de Carajás (de 
onde deveria sair o minério de ferro para abastecimento da siderúrgica) e a localização geográfica privilegiada, próximo aos mercados compradores internacionais. O porto disporia de calado de 15 metros a 22 metros de profundidade na baixa-mar, com capacidade para receber até três navios de uma só vez. Atenderia ao desembarque de matéria-prima (coque/carvão vegetal) e ao escoamento da produção. A previsão era de que o porto movimentasse cerca de 31 milhões de toneladas de carga por ano.

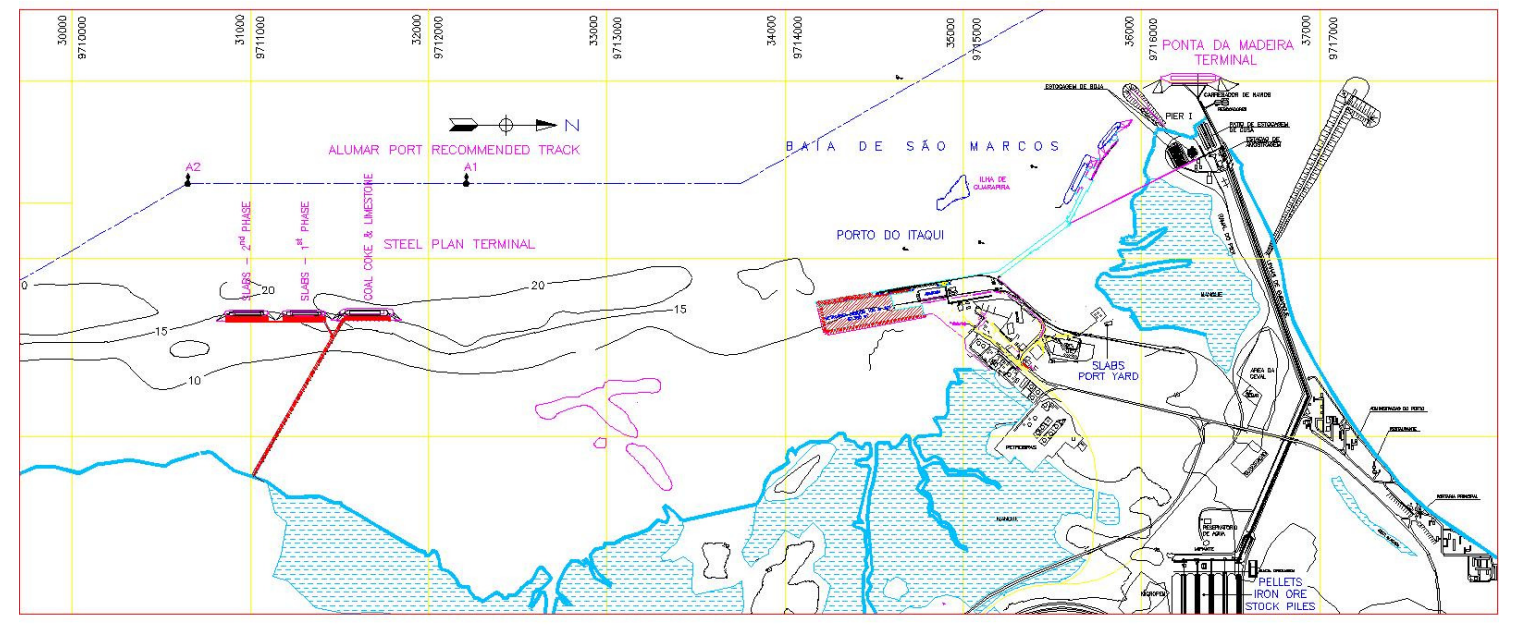

Figura 42: Localização geográfica do Terminal (fonte: FCTH, 2004)

O estudo de locação e viabilidade do Terminal contou com os estudos no modelo físico de Ponta da Madeira/ltaqui, no qual foram realizados ensaios de manobras para as diversas alternativas de locação propostas. Nenhuma das alternativas previa a construção de obras de abrigo para o Terminal.

Abaixo estão relacionados os serviços realizados para adaptação do SIAMA para o estudo:

- Desenho, confecção e implantação dos píeres, bem como suas estacas (Figura 43).

- Confecção e calibração das defensas para os berços. 
- Preparo da instrumentação dos modelos de navios Capesize (150.000 tpb) e Post Panamax (75.000 tpb).

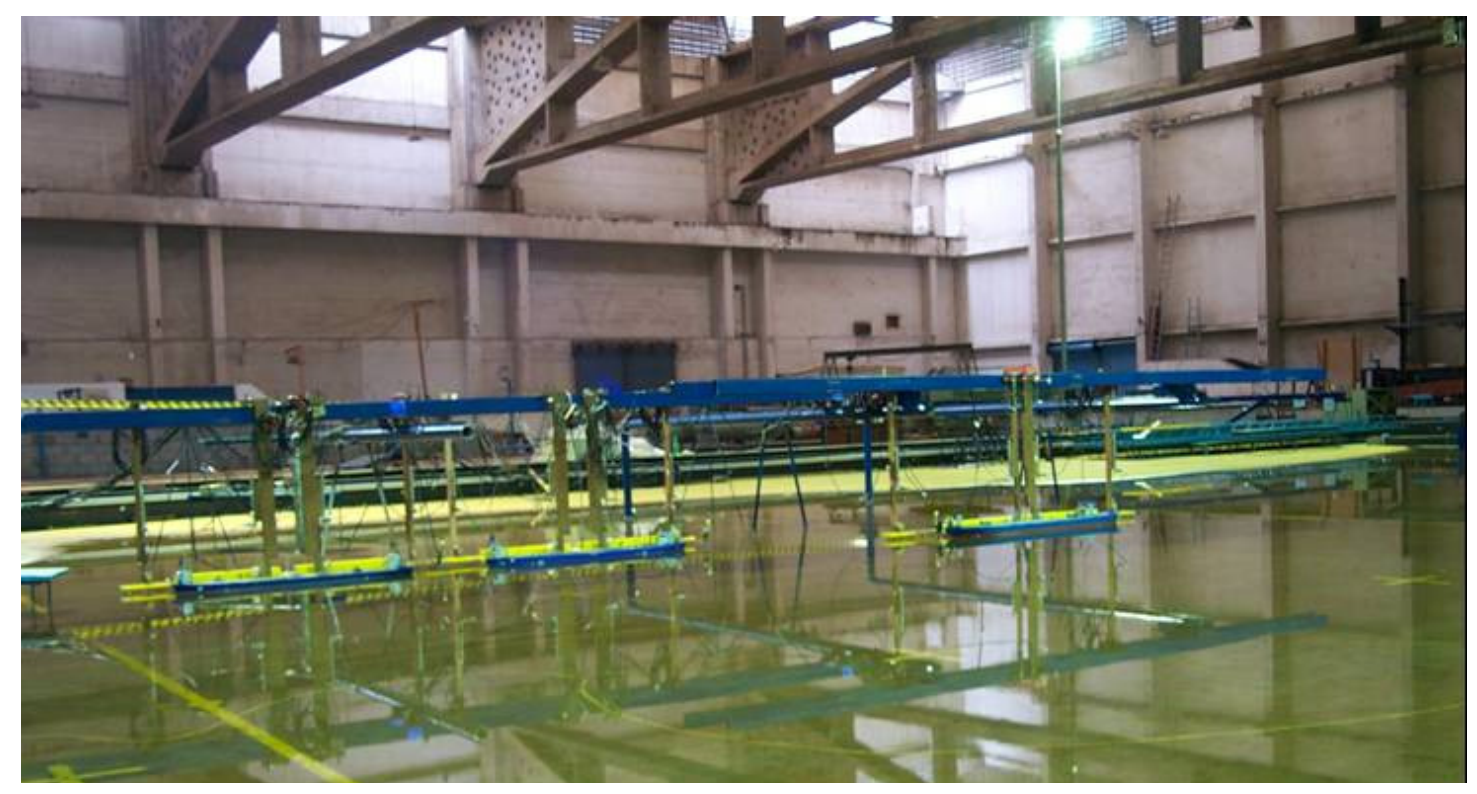

Figura 43: Terminal do Pólo Siderúrgico implantado em modelo físico (fonte: FCTH, 2004)

Ao todo foram realizados mais de 100 ensaios e testes, os quais permitiram concluir que existia plena viabilidade das atracações nos diversos berços do Terminal, independendo da amplitude de maré, entretanto para manobras com giro para a atracação por boreste, uma possível falha de máquina (imprescindível nestas manobras para redução de seguimento do navio), poderia exigir um rebocador adicional com cabo passado pela popa, para corrigir esta possível falha.

A localização escolhida para este Terminal é um exemplo de área exposta e não confinada para manobras de navios Capesize, em condições bem mais favoráveis do que as do futuro Píer IV, devido à reduzida obliqüidade das correntes, que são bem mais alinhadas com o píer, quando das máximas velocidades.

Em janeiro de 2006 o projeto foi cancelado devido a limitações ambientais e dificuldades na disponibilização dos terrenos selecionados para implantação da usina na ilha de São Luis, MA. 


\subsubsection{Aumento da janela operacional do Terminal de 6 para 16hs diárias}

A regra de manobra vigente de 1986 a 2007 determinava que, em função do conhecimento da Praticagem em relação às fortes velocidades das correntes de maré na região, os navios deveriam operar para condições de marés com amplitudes de até 5 metros somente no intervalo de tempo compreendido entre o estofo da baixa-mar até uma hora depois e no intervalo de duas horas antes da preamar até o instante do estofo da preamar (instantes em que as velocidades das correntes são menores), permitindo assim manobras em apenas seis horas/dia (Figura 44).

\section{Regra original $(1986-2007)$}

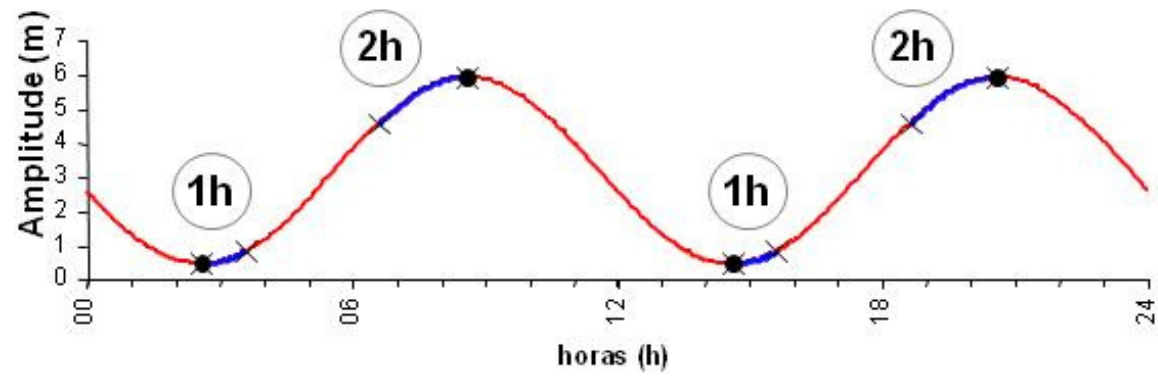

Figura 44: Regra original de manobras para o Terminal de Ponta da Madeira (fonte: CVRD, 2001)

Com base nos resultados dos mais de 1.000 ensaios, realizados no Simulador analógico de manobras não tripuladas do LHEPUSP, houve consenso das autoridades portuárias, marítimas e entidades envolvidas quanto à possibilidade de ampliação dos horários das janelas operacionais de marés até $5 \mathrm{~m}$ de amplitude, contando-se com acréscimo de bollard-pull dos rebocadores, (aquisição de dois rebocadores de $75 \mathrm{tf} \mathrm{BP})$, visando uma maior eficiência na execução do binário do giro (giro mais rápido e menos sujeito ao arrasto das correntes). Também se propiciou a função de sustentar a navegabilidade do navio no caso de uma falha operacional, reduzindo seu abatimento rumo aos bancos de areia da região e contribuindo também para aprimorar as condições de segurança da navegação, uma vez que permitiu otimizar a gestão das unidades em manobras simultâneas para os 
berços do Ponta da Madeira, EMAP e ALUMAR, cujas respectivas quantidades de manobras estão em franco crescimento.

Foram programadas manobras experimentais no real e, após a conclusão dos processos de equalização, adestramento e evolução técnica de toda a equipe envolvida nas manobras, encaminhou-se proposta para homologação das novas regras junto à Capitania dos Portos do Maranhão para validação das novas regras de manobras para o Píer I.

As novas regras de manobras para o Píer I permitiram ampliação dos horários das janelas operacionais de marés de seis horas/dia para dezesseis horas/dia (Figura 45), possibilitando-se manobras de atracação e desatracação desde o estofo da baixa-mar até uma hora depois da preamar, reduzindo o tempo de espera dos navios e propiciando um aumento de mais 6 navios além dos 55 que já manobravam anteriormente por mês, resultando em um ganho de 10 milhões de toneladas anuais na capacidade de embarque do Terminal (incremento de 15\%).

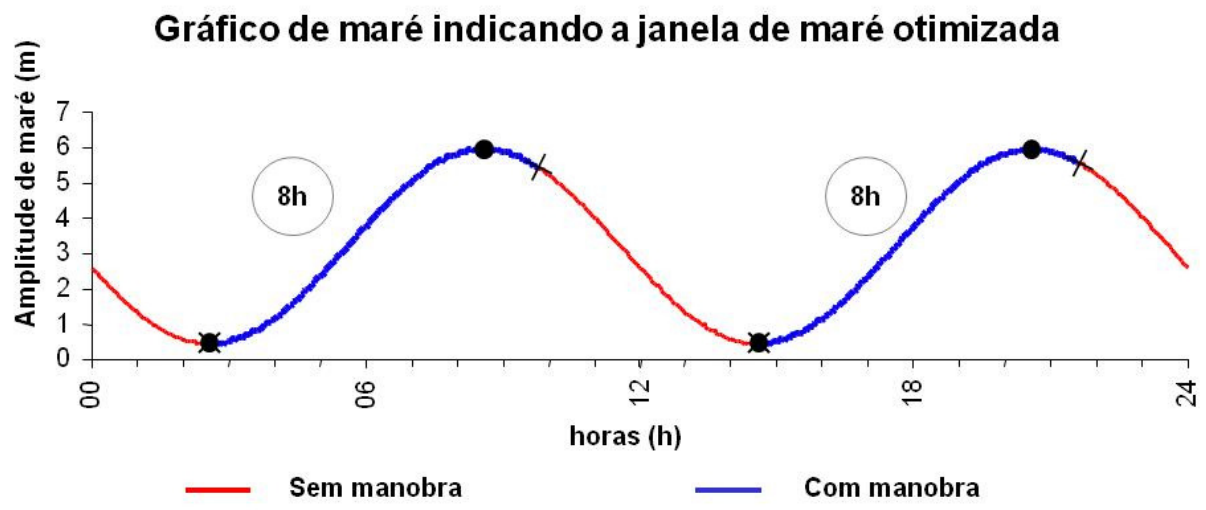

Figura 45: Regra atual de manobras para o Terminal de Ponta da Madeira (fonte: CVRD, 2001) 


\section{DISCUSSÃO}

O modelo físico, bem como o SIAMA, simulador analógico de manobras não tripuladas, são ferramentas que somadas à perícia humana, visam simular a realidade de maneira esquematicamente simplificada, permitindo uma melhor compreensão dos fenômenos naturais hidráulicos e condições atípicas, possibilitando um melhor planejamento operacional portuário.

Como a natureza está em contínua transformação, com condições físicas alterandose constantemente, é fundamental que haja uma rotineira atualização do cenário a ser representado no SIAMA, de acordo com a finalidade do estudo. Nem sempre a condição mais recente levantada em campo, deverá ser a representada, na maioria dos casos deve-se simular a condição mais crítica já levantada no real (ou até extrapolada para uma condição mais crítica que esta), para que haja sempre garantia da segurança.

Da mesma forma, é imprescindível desenvolver uma rotina de verificações do funcionamento dos equipamentos e componentes do simulador, a fim de prevenir possíveis desvios nos resultados dos ensaios por conseqüência de falhas ou erros de medição e/ou calibração.

Por ser uma ferramenta que serve de apoio à tomada de decisões, não pode, em hipótese alguma, ser substituída por outros tipos de estudos, mas sempre completálos, considerando o primado da comparação reiterada de condições sobre os resultados exatamente quantitativos.

A participação de Pilotos reais e profissionais da área portuária é fundamental para a garantia da qualidade das informações geradas pelo simulador, pois a condução dos ensaios, análise das condições simuladas e dos resultados gerados, deve ser realizada por especialistas no assunto. 
Por se tratarem de simplificações da realidade e em virtude da existência de efeitos de escala, possuem algumas deficiências que podem ser amenizadas com a utilização conjunta de simuladores matemáticos.

Segue abaixo a relação de vantagens e desvantagens do uso do simulador analógico de manobras não tripuladas - SIAMA:

\section{Vantagens:}

- Os rebocadores são facilmente ajustados para diferentes potências e operados por rádio-controle;

- Altera-se facilmente a condição de maré e de calado do navio;

- Para a construção e calibração dos modelos de navios não há necessidade da determinação de seus coeficientes hidrodinâmicos e, ao contrário, pode fornecer o padrão de comportamento para os modelos de simulação matemática serem validados. De fato, estudos de situações de contingência efetuados no Simulador Digital de Manobras da Fundação Homem do Mar - RJ, tem-se valido das informações do SIAMA para o TMPM;

- Por ser uma obra civil, através de teodolitos estabelece-se com precisão o relevo de fundo, de acordo com a batimetria informada, para uma realidade mais próxima do real;

- O Piloto real pode manobrar de fora do navio rádio-controlado, o que the permite avaliar o ambiente com mais abrangência;

- É visível a iteração entre casco, leme e hélice com o escoamento;

- O tempo acelerado, em função da escala, permite a realização de uma gama de manobras que demandariam cerca de treze vezes mais tempo (para a escala geométrica linear de 1:170) em um navio real; 
- Possibilita avaliação da força de impacto na defensa, decorrente da velocidade de atracação;

- Permite executar, utilizando-se o mesmo modelo físico, vários estudos, tais como: ensaios de amarração, transporte de sedimentos, eficiência e estabilidade de obras de abrigo, dispersão de poluentes, etc.

- Possibilita controlar separadamente no mesmo cenário, dois diferentes modelos de navios, para realização de ensaios de manobras simultâneas: desatracação seguida de atracação de outro navio, aproveitando a mesma janela operacional de maré. Para tanto, deve haver espaço suficiente no SIAMA e a utilização de dois controles com freqüências distintas.

\section{Desvantagens:}

- Não há rebocadores físicos. Como são substituídos por ventiladores entubados (abertura no costado), não angulam como no real e não interagem com o casco;

- Custo elevado de construção (proporcional à complexidade do projeto) não se coaduna com a realização somente de ensaios de manobras, devendo haver outros aproveitamentos em termos de modelagem física;

- Não há simulação do vento, embora a mesma pudesse vir a ser implementada;

- Em função da escala, a velocidade de simulação requer algum tempo para que o Piloto possa se ambientar e se incorporar na temporalidade acelerada;

- Impossibilidade de realização de manobras com navios de porte inferior a 50.000 tpb, em função da necessidade de embarque dos equipamentos eletromecânicos dos modelos rádio-controlados, que ainda não são suficientemente miniaturizados na escala comercial brasileira vigente;

- A condição hidráulica simulada é estática, não varia com o tempo. 


\section{CONCLUSÕES}

Pode-se comprovar, através dos levantamentos históricos de resultados e da análise crítica desta dissertação, que a simulação analógica de manobras não tripuladas de navios é uma importante ferramenta na otimização de operações náuticas e projetos portuários.

Foi demonstrado este contexto pelos ganhos obtidos em estudos de casos de quatro diferentes portos brasileiros existentes (TMPM Ponta da Madeira, Itaqui, ALUMAR e Ilha Guaíba) e um projetado píer (Píer IV do TMPM), correspondendo a estudos de manobras e acessibilidade em 14 berços de atracação para navios entre 55.000 e 575.000 tpb. A técnica de simulação possibilita a extração de informações valiosas que contribuem para garantir resultados de produtividade e segurança aos terminais portuários estudados.

Com o SIAMA é possível obter resultados que melhoram o conhecimento sobre o conjunto da dinâmica das manobras em diferentes cenários para:

- Estabelecer a melhor estratégia para as manobras dos navios de projeto;

- Estabelecer a melhor estratégia para as manobras em novos píeres/cais;

- Decidir sobre o número de rebocadores e/ou o bollard pull mais conveniente;

- Reduzir o empirismo e riscos associados na execução dos testes em escala real;

- Realizar reconstituição de acidentes/incidentes ocorridos;

- Estudo de locação de cais e píeres de novos projetos portuários.

Estas conclusões foram inequivocamente verificadas em escala real, ao longo da operação dos vários berços dos terminais portuários estudados nos últimos 18 anos. 


\section{REFERÊNCIAS}

ALFREDINI, P. - "A modelação física do comportamento de navios atracados na otimização do arranjo geral de áreas portuárias". Tese apresentada à EPUSP, para obtenção do título de Livre-Docente. São Paulo, 1991. 2v.

ALFREDINI, P. \& ARASAKI, E. - "Obras e gestão de portos e costas, a técnica aliada ao enfoque logístico e ambiental”. Editora Edgard Blücher. São Paulo, 2009.

ALFREDINI, P., GERENT J. P., ARASAKI, E. - "Avaliação de manobras de navio com o uso de simulador analógico em modelo físico". Artigo técnico apresentado no III Seminário e workshop em engenharia oceânica - FURG, 2008.

ALUMAR - "Norma de operação do Terminal Portuário da ALUMAR". São Luiz, 2004 BLAAUW, H.; G.; KOEMAN, J. W. \& STRATING, J. - "Nautical contributions to an integrated port design". Publications Delft Hydraulic Laboratory, n. ${ }^{\circ} 251,1981$.

BOLATTI GUZZO, L. \& CHILO, B. - "La dinamica della nave quale parametro per l'ottimizzazione del progetto portuale". Memorie del Convegno d'Idraulica e Costruzioni Idrauliche, L’Aquila, Itália, 1988.

BORGO FILHO, M. - "Elementos de engenharia Portuária". Vitória, 2009.

BRASIL/MARINHA/DIRETORIA DE PORTOS E COSTAS - "Estabelecimento de dimensões e calados máximos de navios para acesso a portos e terminais". Informativo Marítimo, Rio de Janeiro, 2005.

BRIDGESTONE CORPORATION - "Marine fender system proposal for Ponta da Madeira Brazil”. Japan, 2008.

BRIGGS, M. J.; SILVER, A. L. \& BORGMAN, L. E. - "Risk-based predictions for ship underkeel clearance". Coastal Engineering Conference 2006, Proceedings ASCE.

CENTRO DE INSTRUÇÃO ALMIRANTE GRAÇA ARANHA - SIMULADOR DE MANOBRAS - "Relatório das manobras nos Terminais da ALUNORTE, PARÁ PIGMENTOS E RIO CAPIM CAULIM". Rio de Janeiro, s. d..

CHOW, V.T. - "Open Channel Hydraulics". McGraw-Hill College, 1959. 
COMPANHIA VALE DO RIO DOCE S. A./ SUPERINTENDÊNCIA DE IMPLANTAÇÃO DO PROJETO CARAJÁS - TERMINAL DE PONTA DA MADEIRA "Relatório de manobras dos navios de projeto da DOCENAVE no TMPM", 1982.

CRENSHAW JR., R. S. - "Naval shiphandling”. Naval Institute Press, Annapolis.

DELFT HYDRAULICS LABORATORY - "Puerto Miranda Oil Terminal (Venezuela): nautical problems". Hydro Delft, n. ${ }^{\circ} 10,1968$.

- "Photography and hydraulic research". Hydro Delft, n. ${ }^{\circ} 16,1969$.

- "Navigation studies". Hydro Delft, oct. 1972.

-"Navigability of constraint waterways". Hydro Delft, n. ${ }^{\circ} 50,1978$.

- "Present research technique". Hydro Delft, n. ${ }^{\circ}$ 51, 1978.

FRYER, D. K. - "Tug force simulation in navigational models". Hydraulic Research Station Notes, n. ${ }^{\circ} 18,1976$.

GEOTRON ENGENHARIA ELETRÔNICA LTDA. - "Provas de mar do navio Docelotus". Rio de Janeiro, 1982.

GONÇALVES, R. R. C. - "A criação de um simulador para otimização de manobras de navios com a técnica de modelo rádio-controlado conduzido por Piloto real em modelo físico". Dissertação apresentada à EPUSP, para obtenção do título de Mestre. São Paulo, 2005.

GONZALEZ FERNANDEZ, J. - "Cálculo da força necessária para reboque para o TMPM". Rio de Janeiro, 1990.

- "Relatório do estudo de manobras de navios que demandam o TMPM". Rio de Janeiro s. d..

- "Estudo das manobras de aproximação, atracação e desatracação ao Terminal de Ponta da Madeira". Rio de Janeiro, 1992.

- "Relatório de manobras de atracação e desatracação ao Píer II do TMPM". Rio de Janeiro, 1993.

- "Emprego de rebocadores na operação do Píer II". Rio de janeiro, março de 1994 
- "Forças que afetam o navio e efeito de águas rasas". Rio de Janeiro, outubro de 1994.

GRIFFITH, J. B.; SAMPSON, J. D. \& HUDSON, F. D. - "Handling of super tankers". HEDDE, R. H. A. W. ter \& JONG, J. H. de - "New developments in nautical consultancy and training". Bulletin PIANC n. ${ }^{\circ} 80,1993$.

HENDERSON, F.M. - "Open Channel Flow”. Macmillan Coll Div, 1966

HENSEN, H. - "Tug use in Port - A practical guide". The Nautical Institute, London, 1997.

HYDRAULIC RESEARCH STATION, WALLINGFORD - "Berthing tests on a model tanker of the Bantry Class". Hydraulic Research, 1968.

- "Tilbury dock entrance". Hydraulic Research, 1970.

- "Dover Harbour". Hydraulic Research Station Summary, 1987.

INOUE, S.; NOMOTO, K.; TANI, H.; MOTORA, S.; OKADA, S. \& YAMANOUCHI, Y. - "Researches on the manoeuvrability of ships in Japan". The Society of naval Architects of Japan, Tokyo, 1966.

PERMANENT INTERNATIONAL ASSOCIATION OF NAVIGATION CONGRESSES - PIANC - "Big tankers and their reception". Bulletin n. ${ }^{\circ} 16,1973-1974$.

- "Capacity of ship manoeuvring simulation models for approach channels and fairways in harbours. Bulletin n. ${ }^{\circ} 77$, 1973-1974, Supplement, 1992.

- "Approach channels - a guide for design". Final Report of the Joint Working Group II-30 PIANC-IAPH in cooperation with IMPA and IALA, Brussels(Belgium) and Tokyo (Japan), 1997.

ROWE, R. W. - "The shiphandler's guide". The Nautical Institute, London, 1996.

SÃO PAULO (ESTADO)/LABORATÓRIO DE HIDRÁULICA DA ESCOLA POLITÉCNICA DA UNIVERSIDADE DE SÃO PAULO - "Estudos para aprimoramentos operacionais no Terminal Marítimo de Ponta da Madeira". São Paulo, 1994.

- "Terminal Marítimo de Ponta da Madeira - Estudo do Píer III - Estudo de manobras de navios no Berço Sul”. São Paulo, 2001. 
- "Avaliação das manobras de atracação e desatracação no Berço Norte do Pier III do CPPM". São Paulo, 2003.

- "Navio ULOC - Estudo das condições de amarração e manobras". São Paulo, 2004.

- "Estudo das condições de amarração, circulação e manobras de navios para o Cais 108 da EMAP". São Paulo, 2004.

- "Conseqüências hidrodinâmicas de colisão entre navios no Pier I do PDM". São Paulo, 2004.

- "Avaliação dos acidentes com os navios Savina no Pier I e Kamari no Pier III do PDM". São Paulo, 2004.

- "Estudos das manobras de navios nos berços de Carvão 1 e Placas 1 do projetado Pólo Siderúrgico do Maranhão". São Paulo, 2005.

- "Avaliação de situações de desatracação de emergência para navios Capesize (150.000 tpb) nos píeres I e III (Norte) do Terminal Marítimo de Ponta da Madeira da CVRD, em São Luís (MA)". São Paulo, 2006.

- "Avaliação da flexibilização das janelas dos horários de marés para manobras de navios VLOC (270.000 tpb) e Capesize (150.000 tpb) nos píeres I e III (Sul) do Terminal Marítimo de Ponta da Madeira da CVRD, em São Luís (MA)". São Paulo, 2006.

- "Avaliação da flexibilização das janelas dos horários de marés para manobras de navios Capesize (150.000 tpb) nos píeres I e III do Terminal Marítimo de Ponta da Madeira da CVRD, em São Luís (MA)". São Paulo, 2006.

- "Manobras de navio Berge Stahl no Píer IV do Terminal Marítimo de Ponta da Madeira da CVRD em São Luís (MA)". São Paulo, 2007.

- "Estudos de manobras de navio Capesize no Píer II do PDM". São Paulo, 2007.

- "Estudo de manobras de navios nos Píeres I, III Norte e Píer IV - Alternativa CVRD INTERNA". São Paulo, 2007.

- "Estudos para aprimoramentos operacionais no Terminal Marítimo de Ponta da Madeira". São Paulo, 2008. 
- "Adaptação, ajuste e calibração do Simulador Analógico de Manobras SIAMA. Estudos de comportamento dos navios no Canal de Acesso e em manobras de atracação e desatracação no Terminal Portuário da ALUMAR". São Paulo, 2008. VEROLME ESTALEIROS REUNIDOS DO BRASIL S. A. - "Características de manobrabilidade do navio Docebay (150.000 tpb)". Rio de Janeiro, 1986.

VRIES, W. A. de - "Nautical risk analysis in port and fairway design". Publications Delft Hydraulics, n. ${ }^{\circ} 443,1990$.

ZAIDAN, R. E. - "Análise da geração e propagação de incertezas na modelação física em hidráulica". Dissertação apresentada à EPUSP, para obtenção do título de Mestre em Engenharia. São Paulo, 1994. 